SKETCHES

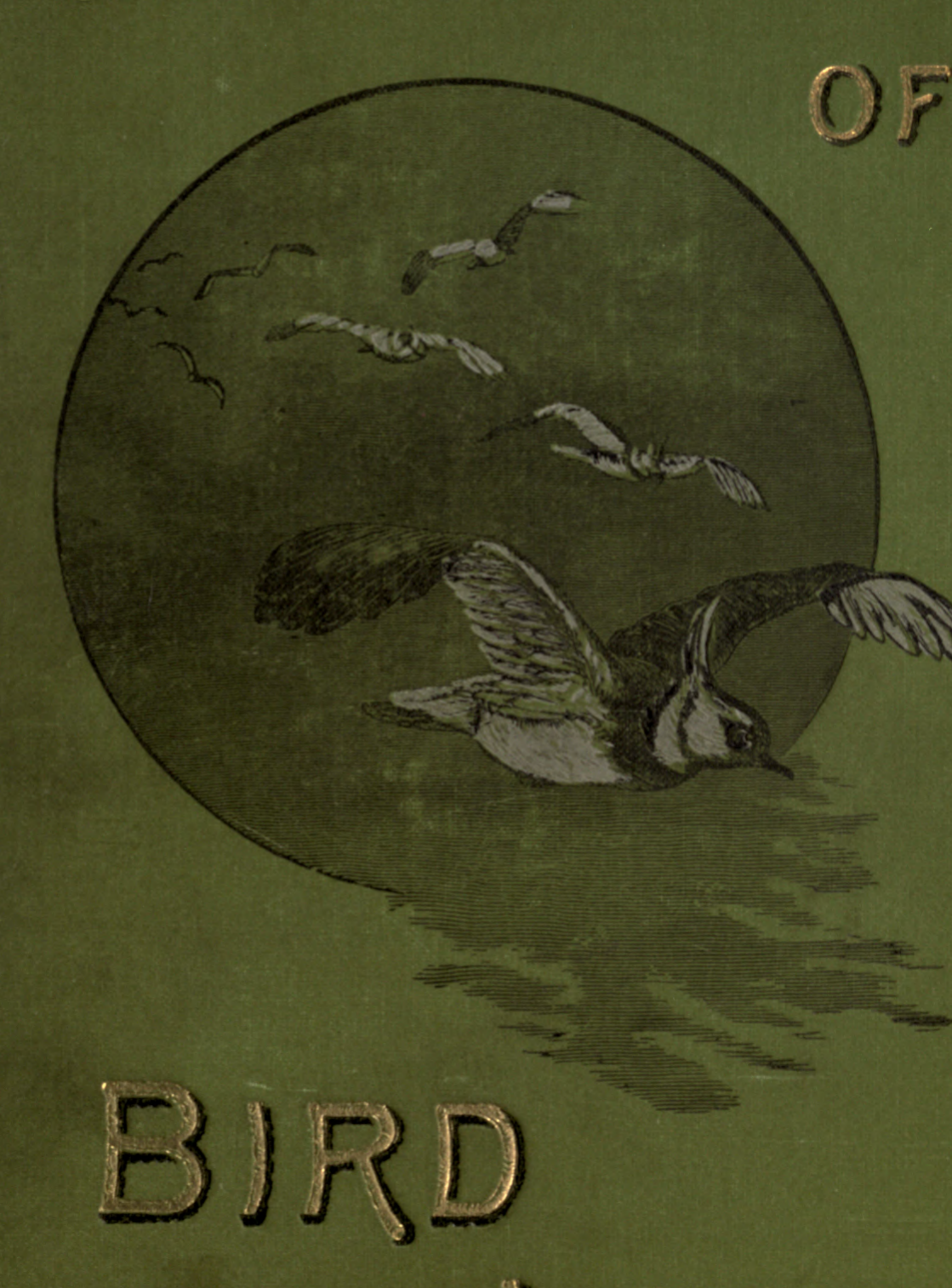

1,158 


\section{us}
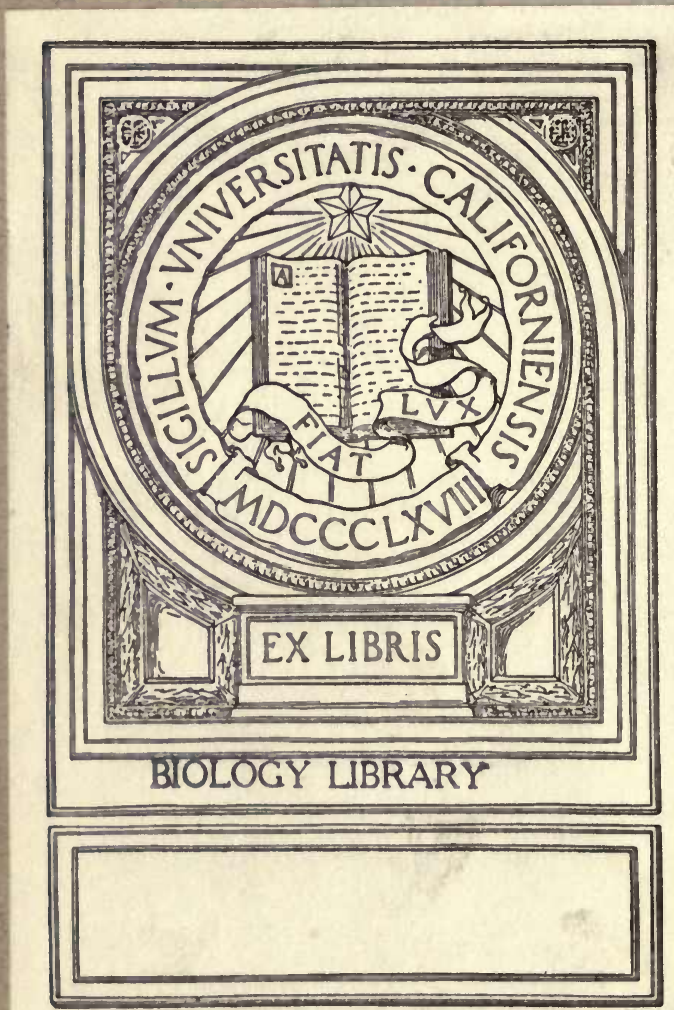


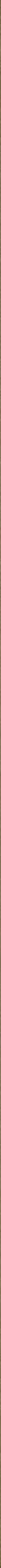



- SKETCHES OF BIRD LIFE 


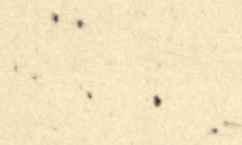

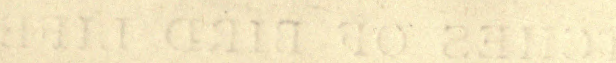




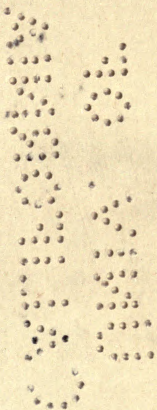




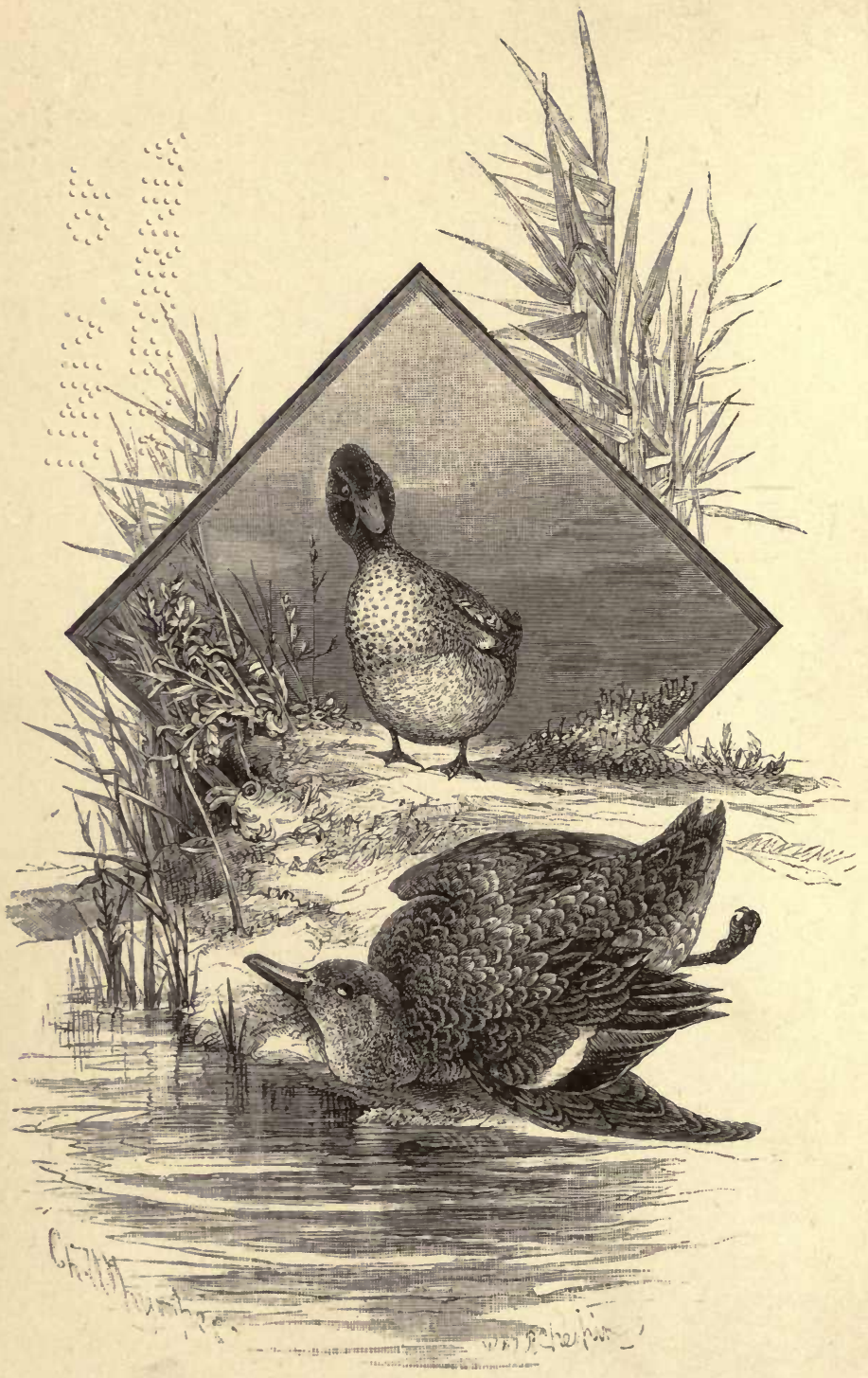

THE DEAD TEAL. Seep. 276. 


\title{
SKETCHES OF BIRD LIFE
}

FROM

TWENTY YEARS' OBSERVATION

OF' THEIR

\section{HAUNTS AND HABITS}

\author{
BY \\ JAMES EDMUND HARTING \\ AUTHOR OF \\ "A HANDBOOK OF BRITISH BIRDS," "RAMbLes IN SEARCH OF SHELLS," \\ AN BDITION OF "WHITE'S SELBORNE," ETC.
}

WITH ILLUSTRATIONS BY WOLF, C. WHYMPER, KEULEMANS, AND THORBURN.

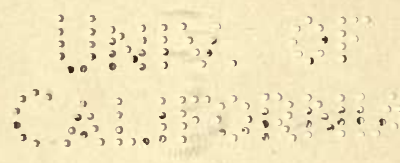

genoron

W. H. ALLEN \& CO. I3 WATERLOO PLACE PALL MALL, S.W.

I 883 


\section{BIOLOGY LIBRARY}

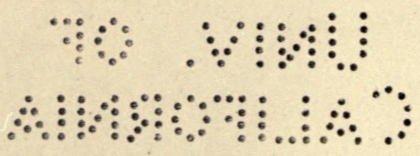

Printed by R. \& R. CLARK, Edinburgh. 


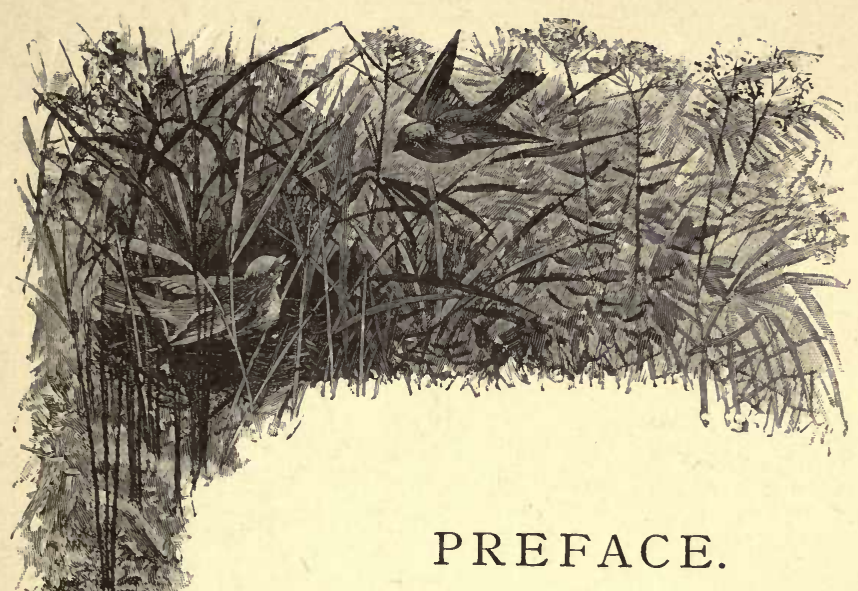

The favour with which these Sketches have been already received by the public has suggested the expediency of republishing them in the more portable and convenient form of an octavo.

All have been written from the Author's personal observation, during many years, of the birds in their natural haunts.

The various scenes of Bird Life so faithfully depicted in the engravings by Mr. Charles Whymper, have all foundation in fact, and will be found to illustrate incidents narrated in the text. 


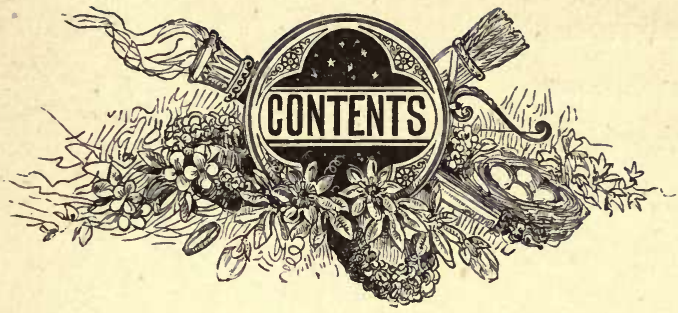

PAGE

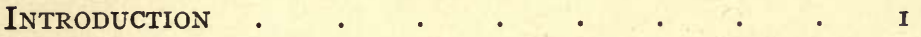

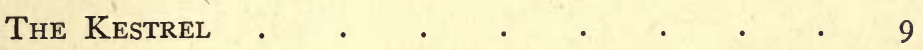

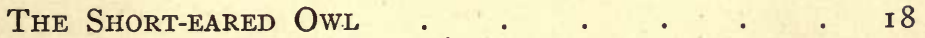

The Thrush . $\quad$. $\quad$. $\quad . \quad . \quad . \quad 25$

The Blackbird . . . . . . . . 32

The Fieldfare . $\quad$. $\quad$. $\quad$ - . $\quad$ - 39

The RoBIN . . . . . . . . . 48

The Nightingale . $\quad . \quad . \quad . \quad 56$

The BlackCAP . . . . . . . . . 64

The Garden Warbler . . . . . . 70

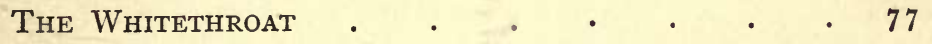

The Great Titmouse $\quad$. $\quad . \quad$. $\quad . \quad . \quad$. 83

The Blue Titmouse . . . . . . . . . 9 I

The Marsh Titmouse $\quad$ - . . . . . . 99

The Coal Titmouse . . . . . . . I06

The Crested Titmouse . . . . . . . II 2

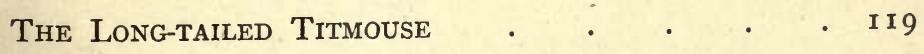

The Golden-CRESTed Wren . . . . . I 26 
The Siskin

The Brambling.

. 133

The Chaffinch

The Grempinch

r 46

The Greenfinch

- $5^{2}$

The Bullfinch .

I 59

The House Sparrow.

65

The Tree Sparrow

. $\quad 173$

The JaY

The Cuckoo

I 80

The Hoopoe

I 86

The Golden Plover.

I 96

The Peewit, or Lapwing

. 203

The Woodcock .

- $2 \mathrm{I} 3$

The Ruff and Reeve

The Curlew

The Heron

220

The Teal.

The Herring Gull.

INDEX 


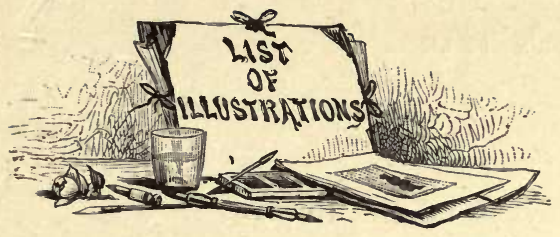

The Dead Teal

PAGE

StaRling Singing

Kestrel and Field-Mouse.

Frontispiece

Kestrel

SHORT-EARED OWL

THRUSH

25

Fieldfare Shooting . . . . . . . 39

RoBIN .

YOUNG ROBIN . . . . . . . . 54

Nightingale $\quad . \quad$. $\quad . \quad$. 59

YOUNG GARDEN WARBLER . . . . . 70

Young of Great Titmouse . . . . . . 83

Great Titmouse. . . . . . . . 86

Blue Titmice • . . . . . . . 92

Marsh Titmouse $\quad . \quad$. $\quad . \quad$. 99

Young Crested Titmouse . . . . . . . i I 2

Long-Tailed Titmouse . . . . . . . . I I9

Siskin . . . . . . . . . . I 33

Male and Female Brambling . . . . . I39 
GREENFINCH

Young Tree Sparrow

THE KEEPER'S TREE

\section{Cuckoo}

HOOPOE

. 182

Golden Plovers in the Snow

Golden Plover .

Peewits

WOODCOCK CARRYING ITS YOUNG .

RUFF AND REEvE

Curlew

Heron following a Setter TEAL .

Herring Gull.

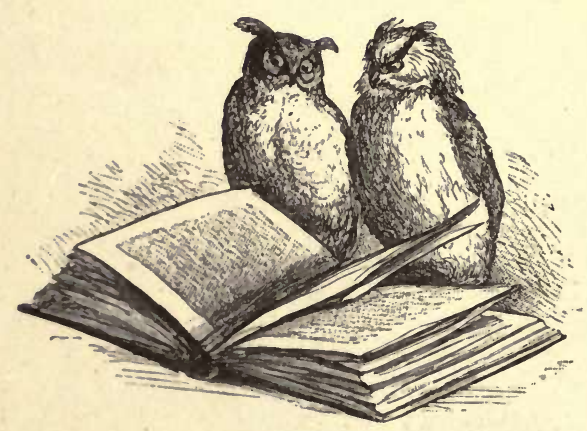




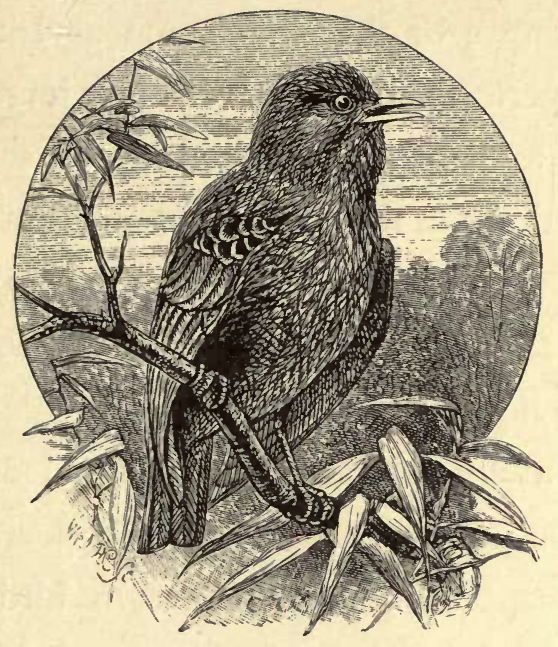

INTRODUCTION.

No matter what the time of year, or place, in which we take a country ramble, some feathered favourite, we may be sure, will greet us with welcome note, or arrest our attention by some peculiarity of habit. In the early spring, as we wander through the larch plantations just coming into leaf, the songs of the Blackcap and the Garden Warbler reach the ear before we can see the authors of the 
notes ; and, behind the ambush of the nearest tree, we have not long to wait before we are enabled to catch a glimpse of the tiny summer visitors which. annually perform their marvellous journeys from the south to pass the summer in our sea-girt isle.

Lower down in the brake, where the tangled briars have caught and held the wind-strewn leaves of the past year, forming a pleasant couch for the outlying rabbit, the liquid notes of the Nightingale are heard, now mournfully prolonged, anon hurriedly brought to a close at our approach, until, as curiosity prompts a closer inspection, the dull-brown bird quits its ambush, and flying low for a few yards is again lost to view amongst the dense underwood. From the top of a larch tree the Thrush pours forth its varied melody, making the woods resound, and the challenge is taken up by a rival in the next plantation. The startled Blackbird, as we quit the copse, flies hurriedly down the ditch with noisy vociferation, and pausing for a moment upon a gatepost, with many a flirt of the tail, dashes wildly into cover again and disappears.

In the hedgerows, as we pass along and mark the budding whitethorn, the restless, garrulous 
Whitethroat comes suddenly into view, and, poised for an instant upon a topmost spray, stands out against the sky, a very picture for soft colouring and graceful outline. Near the farmstead on a bough overhanging the rickyard sits the Greenfinch, giving forth its monotonous though not unpleasant call-note, occasionally dropping down amongst the Sparrows to share a meal with them. Hard by a pair of Robins have decided upon a nest in the woodstack, where for the last two years they have successfully reared their young. From the leafy branches of an elm is heard the spring song of the Chaffinch, whose conspicuous colours and active habits do not suffer him to remain long unrecognised.

Anon the scene changes. The summer has passed away, and with it many of those feathered visitors whose presence for so many months enlivened our groves and garden. Chill October has come, and we are standing, gun in hand, by the cover side watching the falling leaves, and listening for the whirr of wings which betokens the rising of a Pheasant. But the beaters are a long way off yet; we can scarcely hear the sound 
of their sticks; and there is little to break the stillness save the sighing of the wind, and the occasional cracking of a twig as a hare attempts * to steal by.

The earliest intimation of the approach of the beaters is usually given by the advance of numerous small birds, which, disturbed by the unwonted "tapping" and strange voices, hurry to the front, and unconsciously exhibit themselves at close quarters to the motionless sportsman. Conspicuous amongst these at all times are the Tits, which are essentially woodland birds, and are resident with us throughout the year. When from scarcity of food and reduced temperature the summer birds have all fled, the Tits still seem able to get their living, and are as active and joyous amidst the leafless woods in October, as when well-nigh concealed by the thick foliage of spring.

Very social in their habits are the Tits, and it is no uncommon thing to see two or three different species in company. Conspicuous by its size and black and yellow plumage, the Great Titmouse is sure to attract the attention even of the least observant; nor is it at all shy in its habits. Its 
whereabouts is soon made known by its loud call, which varies according to the season of the year, and at times is not unlike the noise produced by sharpening a saw. Of its habits we shall have more to say anon.

Scarcely less beautiful in colour is the little Blue Tit, whose delicate plumage of ultramarine distinguishes it readily from all others of its kind. The Coal Titmouse, with its black head and white nape, is less demonstrative and vociferous than either of the two just mentioned; but like them it loves company, and may often be seen with them hunting for insects on the same bough. The most unassuming of all the family is the little Marsh Tit, whose sombre garb contrasts strongly with the brighter plumage of its congeners. In general coloration it is not unlike the Coal Titmouse, but may be readily distinguished by the absence of the white spot which is so conspicuous on the nape of the latter species.

Amongst the various glimpses of bird-life to be obtained in the woods, there are few prettier sights than a family party of Long-tailed Tits, when, unconscious of man's presence, they approach within a 
few yards in their apparently endless diversion of "follow-my-leader." One after another they come trooping along to the number of ten or a dozen, their long tails, variegated with white, prettily streaming in the wind, while their call-notes sound in the still woods like the tinkling of tiny silver bells. How these delicate little creatures contrive to find subsistence, and withstand thè cold, during an English winter, is marvellous. They are resident with us throughout the year, or at least are only partially migratory; that is to say, they move gradually southwards at the approach of winter, but do not all quit the country at that season, as do the so-called summer migrants. And yet one would scarcely imagine that the Long-tailed Titmouse is better qualified to withstand the rigours of winter than the Whitethroat or the Willow Wren.

Another hardy little bird, of which we shall obtain a glimpse presently, is the Goldcrest. It is not exactly a winter visitant, for its tiny nest is to be found in various parts of the country every summer; but it is more frequently seen in winter perhaps than at any other season, partly because the absence of leaf admits of its being more readily observed then, 
and partly because, being migratory, small flocks attract attention where one or two solitary pairs might escape notice.

If we stroll through the beech woods in winter, and it has been a good year for "mast," we shall be almost certain to see the Brambling, or Mountain Finch, a handsome little bird, not unlike a Chaffinch in its movements and general appearance at a distance, but distinguishable by the white patch at the root of the tail, which is very conspicuous when the bird is flying. It is particularly fond of the beech-mast, and where this is plentiful sometimes assembles in large flocks to devour it. The expectation of finding these in their proper season, and the search for them in the most likely haunts, constitute one of the many pleasures to be derived from a woodland ramble. Not that the woods have no other attractions for those who have eyes and care to use them; for who has not experienced the pleasure of discovering a new insect, shell, or wild flower? Who has not gazed admiringly for the first time on a rare fern or remarkable fungus? But it is the birds which give life to the woods, which charm us with their varied plumage, and help to 
break the solemn silence that in their absence would reign around.

Nor is it in the woods only that their presence. charms us. The wild moorland, the lonely fen, the tidal harbour, and the sea-girt shore, have each and all their feathered occupants as different in their habits as they are in their flight and in their notes. They provide us with endless opportunities for amusement as well as instruction. For what more instructive than to observe the curious adaptation of structure to habits which so many birds present, and to note the various ways in which their food is obtained and life sustained in the "struggle for existence." We may examine the nature of their food, and satisfy ourselves by personal observation of their utility, or otherwise, to man as a cultivator of the soil; we may study their architecture with advantage, and derive pleasure from a comparison and analysis of their various songs and notes. In fine, from whatever point of view we choose to take up the study of birds, we shall find the subject practically inexhaustible. The more we observe the more we find to learn, and the more we become impressed with the wisdom of the Creator as displayed in the creation. 


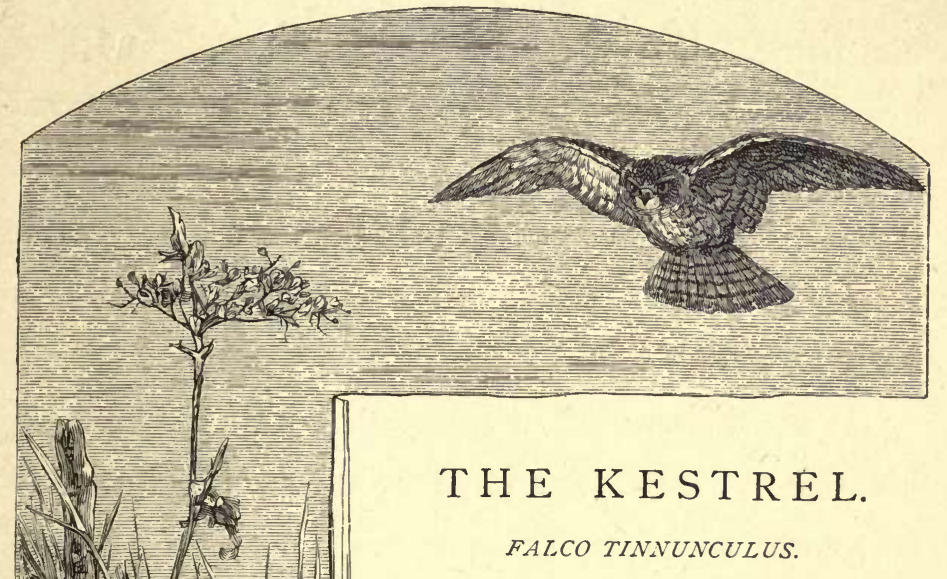

WHen falconry was at its zenith in England, and men of every

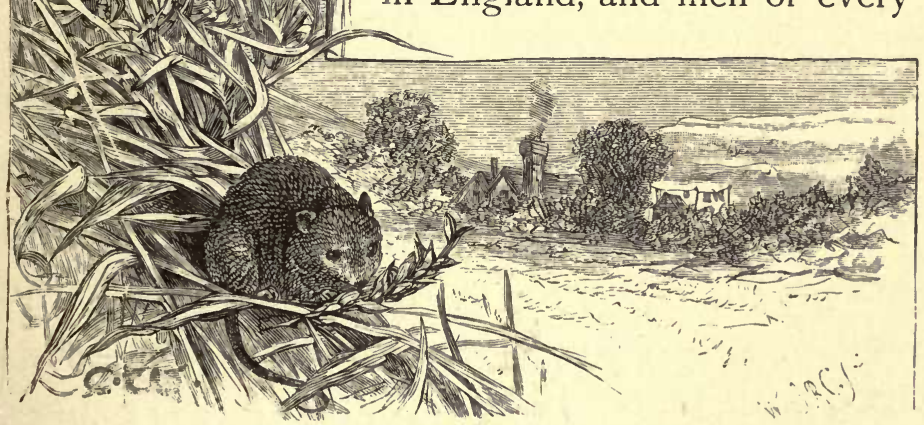

rank, from king to peasant, had each a particular species of hawk according to his rank, the commonest of all was assigned to the peasant or serving man-coistrel-as he was called, perhaps 
from the Latin coterellus. From this circumstance it is probable that our modern Kestrel derived his name. We find the word variously spelled by different authors. Shakespeare has coystril ("Twelfth Night," act i. sc. 3), and coistrel ("Pericles," act iv. sc. 6). Blome, in his Gentleman's Recreation, I686, writes it castrell; while as early as I6I4 we find it as kesterel. ${ }^{1}$

What a change has taken place since the lastmentioned date with regard to hawks in England! Formerly the Kestrel was as much protected by law as the Pheasant is nowadays. In Domesday Book a hawk's " eyrie," or nest (aira accipitris), is returned amongst the most valuable articles of property. In the "Carta de Foresta," which King John was compelled to sign, privilege was given to every free man to keep eyries of hawks, falcons, and herons, in his woods. Edward III., who was wonderfully fond of hawking, passed some very stringent laws for the preservation of hawks. One of these statutes, passed in the thirty-seventh year of his reign, made it a felony to steal a hawk, and not only had the offender to pay the value of the bird by way

${ }^{1}$ A Fervel for Gentrie. London, 16r4. 


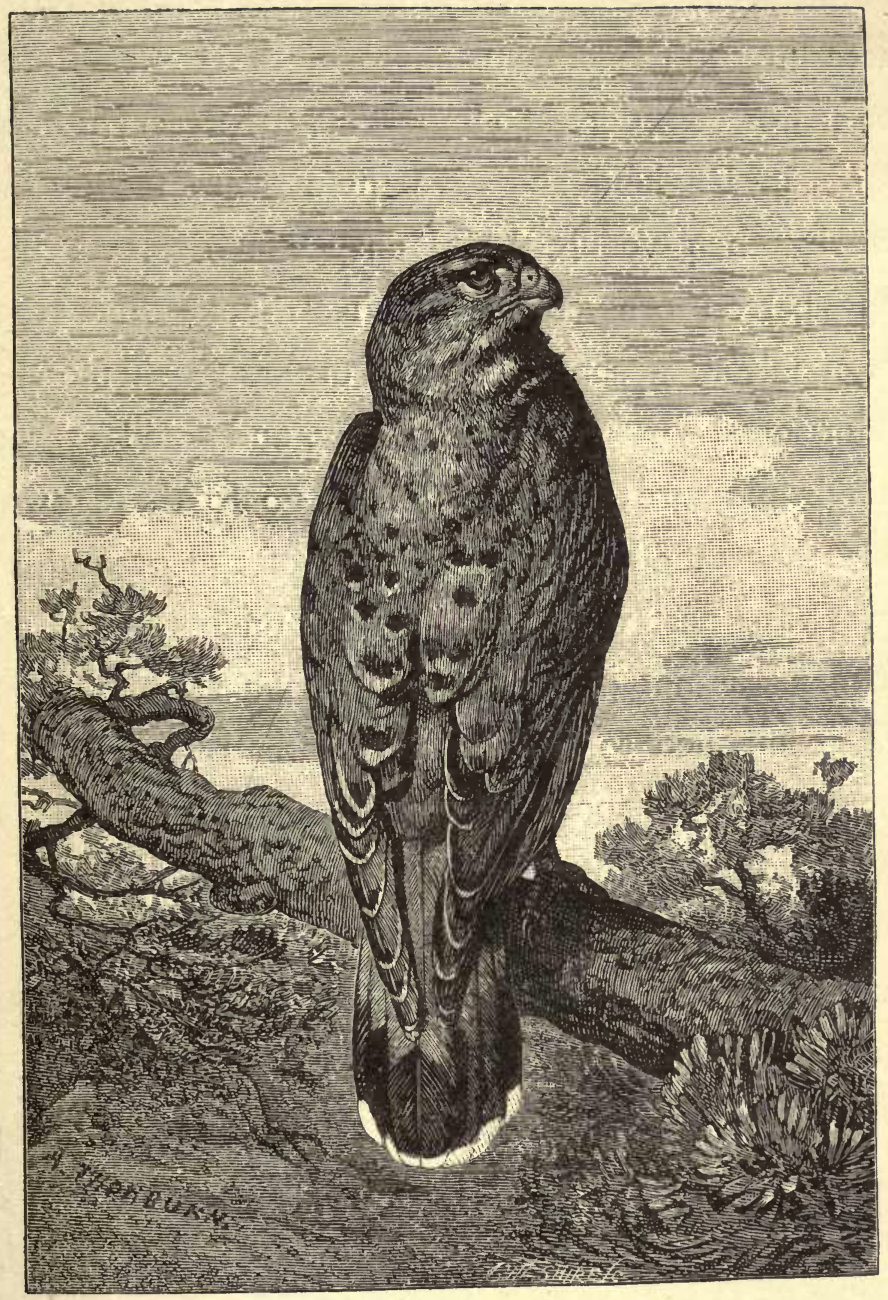

KESTREL. 
of fine, but he suffered imprisonment for a term, according to the circumstances of the case. Later on it was considered so important to preserve these birds in England and give them every facility for rearing their young, that Henry VII. decreed that any person convicted of taking the nest or eggs of a falcon, goshawk, lanner, or swan, should be imprisoned for a year and a day, and fined at the king's pleasure; half the fine to go to the Crown, and the other half to the owner of the ground on which the nest was taken. Even on his own land a man was not permitted to infringe this law, but was compelled to import from abroad what hawks he required for sport. When, however, the musket was introduced into England, and people learnt the art of shooting birds on the wing, the practice of hawking declined, and with it the necessity for the stringent laws just mentioned. Accordingly Elizabeth modified, and in a great measure repealed, these statutes, which more recent legislation has entirely swept away. When we compare the Kestrel of old, strictly preserved, reared, petted, and tamed, with the bird of the present day, which is persecuted on all sides, shot and trapped as "vermin," and either 
nailed against a barn, or miserably stuffed by a village barber, we cannot but regret the change which has taken place and the want of wisdom which has caused it.

There are few prettier sights in nature than the manœuvres of a Kestrel on the wing. We never see its wonderful, almost motionless hovering without thinking of the Ettrick Shepherd, who sang of the Merlin :

"And the Merlin hung in the middle air,

With its little wings outspread, As if let down from the heavens there

By a viewless silken thread."

From this peculiarity in its flight, as well as from its brown colour and more pointed wings, the Kestrel may be distinguished on the wing from the rounder-winged gray and Sparrow-hawk. We have often been surprised at the ignorance displayed by keepers on the subject of hawks. Many of them not only do not know a Kestrel from a Sparrowhawk, but they actually admit that, although they have shot hundreds, they have never proved by dissection that their surmises with regard to its food were well founded. 
Venturing to remonstrate once with a keeper who had just shot a Kestrel, and would persist in calling it a "Sparrer-'awk," he said, "Lor' bless you, sir, I've shot scores on 'em. I know he (pointing to the bird) as well as I know this here dawg, and there ain't a greater varmint out. I'll be bound he's had some o' my young birds." We held a postmortem, and instead of a young pheasant, we found he had been dining off a short-tailed field-mouse, with grasshoppers for second course, and the keeper was obliged to admit that he could not grudge him that fare. We begged hard for the poor Kestrel, but it is difficult to overcome a prejudice, and keepers have always a ready excuse, though oftentimes a poor one, for what they do.

A friend in Sussex once found a Nightjar strung up with a lot of stoats and jays in his keeper's "museum." He immediately reproved the man for killing it. The keeper declared it was "a specie of 'awk;" but his master pointing to the bill and feet, clearly showed him that it was no such thing, and concluded by saying that for the future he wished such birds preserved. One would have thought that this would have silenced the man. Determined, 
however, to find an excuse, he said, scratching his head, "Well, sir, it's a narsty floppin' thing!"

But to return to the Kestrel. We have often been asked how it is that Kestrels appear to be so much more numerous in autumn than at any other time of year. There are many ways of accounting for this. Generally speaking, the observers are sportsmen, who cross the country more frequently in the fall of the year, and therefore notice the birds oftener. Then, again, by the time that young Partridges are ready to fly, Kestrels are strong on the wing, and for every pair seen in spring, were it not for traps and guns, we may expect to find six or seven birds in autumn, for this species usually lays five eggs. But perhaps the best reason is that the Kestrel is migratory in its habits. The old birds move northward in spring, and return southward in autumn, when their numbers are reinforced by the young which have been hatched in the meantime; so that we see not only those which have spent the summer in our own neighbourhood, but numbers which have come from a distance, and which are passing onwards, hunting for food by the way. 
It is worthy of remark that at the season when Kestrels are most numerous, the hay is stacked and the corn carried. Consequently, the long-tailed field-mouse (Mus sylvaticus) and the common meadow-mouse (Arvicola agrestis) are deprived of the friendly cover which has sheltered them throughout the summer, and are more easily espied by the Kestrels, who destroy them in numbers, and thus help to save our crops for the coming year.

In this good work they are joined by the Owls, particularly the Barn Owl (Strix flammea); and if there were no other reason for preserving these birds, this alone, one would think, should suffice.

The adult male Kestrel is characterised by his slaty-blue head and tail, and more intensely rufous back. The female is more sombre in appearance and more spotted, and never assumes the slaty-blue colour above referred to. They pair early in the year, and generally take possession of an old crow's nest, which they repair and sometimes re-line.

Instances, however, are on record of Kestrels nesting in hollow trees after the fashion of Owls. In the summer of 1876 a pair nested in the hollow of an old pollard at Bromley, Kent. The nest was 
not more than ten feet from the ground, and contained six eggs, four of which were taken, and the remaining two in due course hatched. Mr. J. H. Gurney jun. saw two Kestrels' nests in Surrey during the summer of $188 \mathrm{I}$, both of which were in holes of trees. One was about two feet down in an elm, the other about a foot down in an ash.

The eggs, usually five in number, vary from a light brick-red or sandy colour to a dark chestnut. This colour is distributed over the surface in small spots or blotches, sometimes so thickly as to obscure the originally white ground colour of the egg. We have occasionally seen eggs of this species blotched with chestnut at the larger end only, the remainder being pure white, and resembling in this respect eggs of the Sparrow-hawk. They had not, however, that bluish or greenish cast on the inside of the shell which is always apparent on holding an egg of the Sparrow-hawk up to the light. Kestrels may frequently be observed in the breeding season flying about cliffs facing the sea, on the ledges of which they nest like Peregrines. 


\section{THE SHORT-EARED OWL.}

OTUS BRACHYOTUS.

AlL sportsmen should be naturalists; their rambles across country in search of fur and feather give them opportunities for observation which fall to the lot of few besides themselves; while, by virtue of their "license to kill," they are led to explore sundry out-of-the-way holes and corners, which under other circumstances would be passed by. In this way they unavoidably become acquainted with many birds and animals which are not included in the list of "game," but which, nevertheless, by the beauty of their plumage, or by their graceful movements, contribute greatly to the pleasure of a day's shooting.

What sportsman does not remember the occasion of his first acquaintance with the Short-eared Owl ? It was early in October, the weather still fine, but 
just beginning to get a little cold. In the cover through which we passed, the leaves had already changed colour, and the squirrels in their passage aloft sent down a thick shower to strew the ground, over which in turn the rabbits rustled as they scampered away at our approach. Anon we heard the Green Woodpecker with his loud laughing cry, and stayed so long to watch his vigorous blows upon the old beech, that we had almost forgotten that our object in leaving home was "shooting." It was just about the time for the Woodcocks to arrive, and we were anxious to meet "the first cock of the season," and give him a warm reception. Passing out of the cover and crossing a stream, we found ourselves upon an open waste covered with two species of heath and the spongy sphagnum. A more promising spot could not be found. The Woodcocks, if arrived, would be sure to leave the cover in the evening to feed along the stream, and would doubtless remain out all night. Partridges would surely be lower down among the dry heather, and very possibly we might find a Jack Snipe or two, for we have known the last-named to arrive as early as the $2 \mathrm{~d}$ of October. Inserting a couple of 


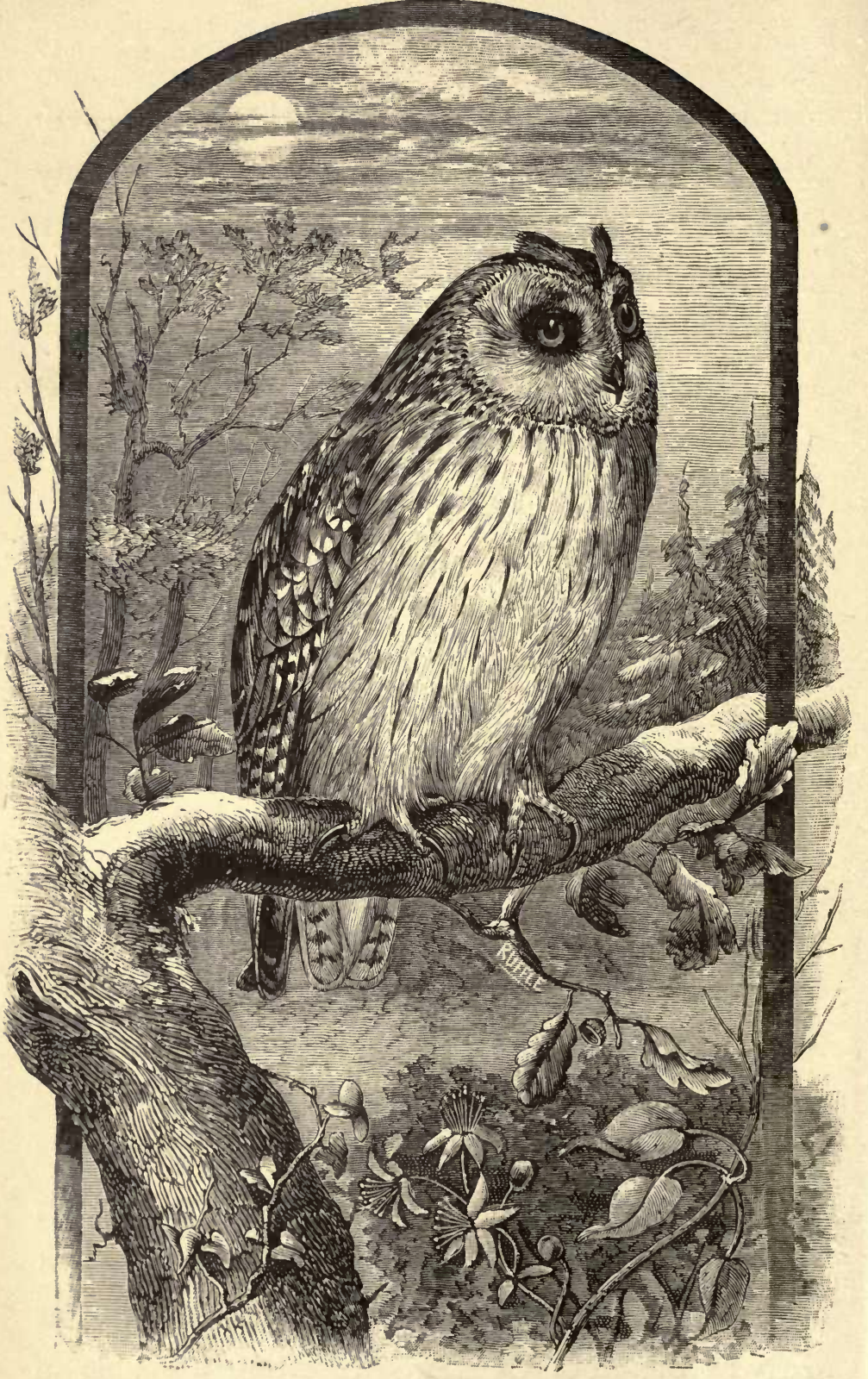

THE SHORT.EARED OWL. 
cartridges, we walked quietly on, when suddenly the dog stood, and before we could reach him, a brown, long-winged bird rose out of the heather and was sailing away. "It's one of these ere owls," exclaimed the keeper, with his usual disregard for species, and immediately brought it down. What a pity! It was a Short-eared Owl, sure enough, and as we stretched out its beautiful barred wings, smoothed its soft plumage, and gazed into its large golden eyes, we felt pained to think that in another moment its life would be gone. The keeper said it was a destructive bird, but he was not prepared with any evidence to support his statement. To judge from the habits of other owls with which we are better acquainted, we should say that small birds, field mice, and beetles constitute its principal food.

In the South of England, and in Ireland, the Short-eared Owl is known only as a winter visitant, and from usually arriving about the same time as the Woodcock, is often spoken of as the Woodcock Owl. In the North of England and in Scotland this bird frequently remains throughout the year, and makes its nest upon the ground 
amongst heather, or in a marsh amongst sedge and rushes.

Mr. A. G. More, who has been at great pains to ascertain the distribution of birds in Great Britain during the nesting season, ${ }^{1}$ says that this owl breeds in Suffolk, Norfolk, ${ }^{2}$ and Cambridge; formerly also in Huntingdon (Mr. F. Bond). The nest has been once or twice taken near Scarborough (Mr. A. S. Bell); in Durham and Northumberland (Mr. Hancock and Rev. H. B. Tristram); Sir William Jardine also mentions the moorland ranges of Westmoreland and Cumberland as probable breeding-places. In Scotland the Short-eared Owl nests regularly in Dumfries (Sir W. Jardine); on Ailsa (Mr. R. Gray); in the counties of Selkirk and Roxburgh occasionally (Mr. J. F. Whitecross); in Stirling (Mr. J. Murray); Clackmannan (Dr. P. Brotherson); in Perth (Mr. A. Pullar); in Ross, Sutherland, Caithness, the Hebrides, and Orkneys.

1 See The Ibis for 1865 , p. 15.

${ }^{2}$ With regard to Norfolk, Mr. Stevenson says: "In the spring these birds again proceed northwards towards the end of March, having, I believe, entirely ceased to breed in Norfolk, where, especially in :the once fenny districts of the south-western parts of the county, they were commonly met with during the breeding season."-Birds of Norfolk, 1866, vol. i. p. 50. 
The eggs are usually five or six in number, white, smaller in size than those of the Barn Owl, and smoother in texture.

Unlike its congeners, the Short-eared Owl evinces no partiality for woods, but affects the open country, roosting upon the ground by day, under shelter of dry grass, sedge, or heath, and hunting for its food as soon as the sun has disappeared. We have often thought, however, when watching the flight of one of these birds when disturbed in the daytime, that its bolder and more hawk-like flight, and the fact of its living out in the open country, indicated habits less nocturnal than those of other Owls. Its sight is wonderfully keen, and if once disturbed and not shot, it is almost impossible to approach within range of it a second time. It has been stated on the authority of Capt. Portlock, in the Proceedings of the Royal Irish Academy (vol. i. p. 52), that in a rabbit warren at Magilligan, county of Londonderry, where the Short-eared Owl is a regular visitant in autumn, birds of this species have been seen at the entrance to the burrows, within which they retired when disturbed: more than one was shot on emerging from a hole, and one was 
taken in a trap placed at the entrance of a burrow when making its exit thence. ${ }^{1}$ Whether they entered the holes for concealment, or for the purpose of, carrying off young rabbits, the observer was not able to determine. There can be no doubt that the Short-eared Owl would take young rabbits where the opportunity occurred; but as it is seldom found in England except between the months of September and April, it cannot commit that havoc amongst young game birds of which, in common with other Owls, it has been so frequently accused.

1 Thomson's Natural History of Ireland (Birds), vol. i. p. 9ז. 


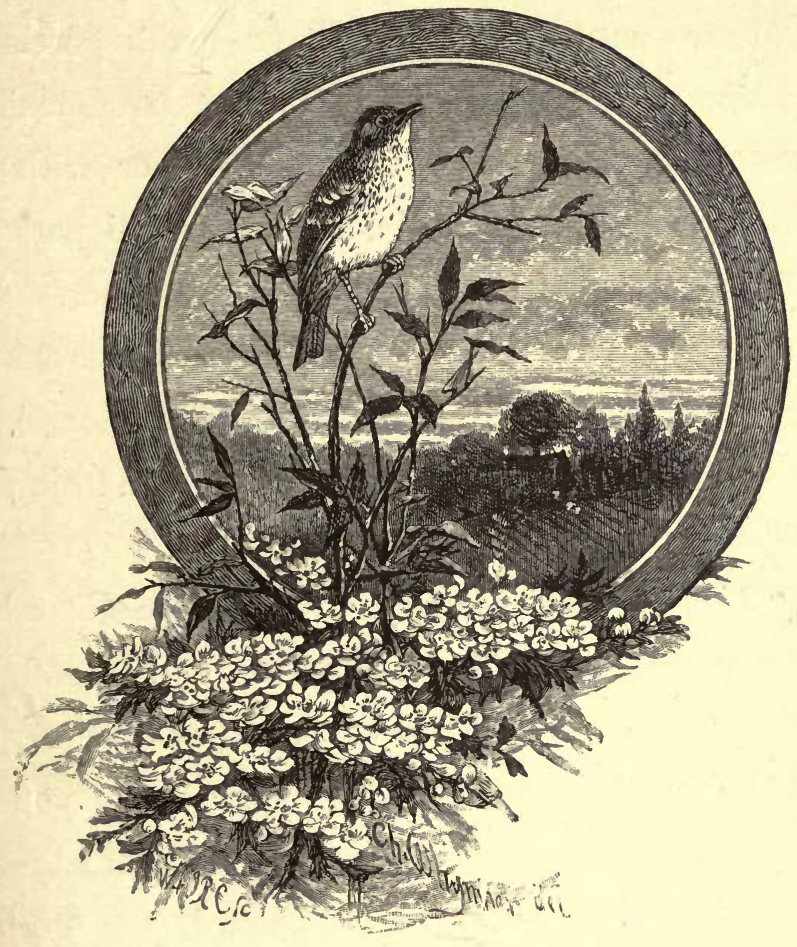

THE THRUSH.

TURDUS MUSICUS.

LoNG before the trees have put forth their spring foliage the loud clear notes of the Thrush may be heard from some lofty spray, awakening the echoes of the woods, and all the more remarkable 
from the comparative silence of the feathered choir at this early period of the year.

Many naturalists who have paid particular attention to the song of the Thrush have insisted upon its taking equal rank as a songster with the more favoured Nightingale, and untutored ears not unfrequently mistake the one for the other. Certainly the notes of this bird, although not so varied, nor so liquid, so to say, as those of Philomel, are yet of a clear rich tone, and have something indescribably sweet about them.

"Listen," says Macgillivray, "to the clear loud notes of that speckled warbler, that in the softened sunshine pours forth his wild melodies on the gladdened ear. Listen and think how should you describe the strain so as to impress its characters on the mind of one who never heard it. Perhaps you might say that it consists of a succession of notes greatly diversified, repeated at short intervals with variations, and protracted for a long time; that it is loud, clear, and mellow, generally sprightly, but at times tender and melting. Listen again, and say what does it resemble?- 
" Dear, dear, dear

Is the rocky glen;

Far away, far away, far away

The haunts of men.

Here shall we dwell in love,

With the Lark and the Dove,

Cuckoo and Corn-rail,

Feast on the banded snail,

Worm and gilded fly :

Drink of the crystal rill

Winding adown the hill,

Never to dry.

With glee, with glee, with glee,

Cheer up, cheer up, cheer up, here,

Nothing to harm us, then sing merrily,

Sing to the lov'd ones whose nest is near :

Qui, qui, qui, kweeu, quip,

Tiurru, tiurru, chipiwi.

Too-tee, too-tee, chiu choo,

Chirri, chirri, chooee,

Quiu, qui, qui."

So far as words can express notes, this is certainly a wonderful imitation of the song which may be heard throughout the greater part of the year. It commences with the first mild weather, and continues until the bird begins to moult, after which it is resumed again during the autumn.

To very few indeed can the strain be unfamiliar, for with the exception of Shetland, where it may be 
said to be unknown, the Thrush is generally distributed as a resident species throughout the British Islands.

In summer it prefers the woods and hillsides, the bushy banks of streams, and sheltered places at some distance from human habitations, although in cultivated districts it often nests in the orchards, gardens, and hedges. In winter the individuals which made the woods and glens their summer residence approach the houses, and feed in the gardens and fields, or betake themselves to the sea-shore, where they find subsistence by breaking shells and other shell-fish. ${ }^{1}$ Our resident Thrushes in autumn receive considerable additions to their numbers by migratory flocks from the north, as every sportsman must have observed when walking the turnip fields in September.

In a paper "On the Migratory Habits of the Song Thrush," printed in The Ibis for I860, Professor Newton has expressed the opinion that this bird throughout the greater part of its geographical range is "essentially migratory." Referring to observations made by himself and his brother in

1 Macgillivray, British Birds, vol. ii. p. I33. 
West Norfolk, he says: "Year after year we have noticed that, as summer draws to a close, the birds of this species (at that season very abundant) associate more or less in small companies. As autumn advances, their numbers often undergo a very visible increase until about the middle of October, when a decided diminution begins to take place. Sometimes large, but more generally small, flocks are seen passing at a considerable height overhead, and the frequenters of the brakes and turnip fields grow scarcer. By the end of November hardly an example ordinarily appears. It is true that sometimes, even in severe weather, an individual or so may be found here and there, leading a solitary life in some sheltered hedge-bottom or thick plantation which may afford conditions of existence more favourable than are elsewhere to be met with; but this is quite an exceptional occurrence. Towards the end of January or beginning of February their return commences. They reappear at first slowly and singly; but as spring advances in considerable abundance and without interruption, until, in the height of the breeding season, they by far out-number their more stay-at-home cousins, the Blackbirds." 
The food of the Thrush varies according to season. Worms, of course, form a staple article of diet; and we take it that the original, and now proverbial, "early bird" was unquestionably a Thrush, although no "early ornithologist," it would seem, has taken the trouble to settle the point. On snails it preys largely, the favourite species sought for being the thin-shelled Helix hortensis and nemoralis, and in default of these the stouter $H$. aspersa and arbustorum. It sometimes happens that a Thrush, after breaking or chipping a shell, is frightened away before he can extract the snail, which contrives to crawl away and conceal itself. In such cases the snail has power to repair the damage it has sustained, and a new shell forms where the old one has been destroyed. This is effected by a secretion of the mantle composed chiefly of carbonate of lime, with a small proportion of animal matter. Few observant persons can have failed to remark these mended snail-shells in the course of a walk, although they may not at once have surmised the cause of the accident and the mode of repair. The bird breaks the shells by raising them in its bill and knocking them repeatedly against a stone. Large 
heaps of the shells thus broken may be seen by garden walls, and in pastures on the edges of thickets. Macgillivray states that in the Hebrides, where it frequents the shores in winter, it treats in the same manner Turbo littoreus and Trochus conuloides, and fragments of these shells may often be found under shelter of some stone or slab, to which the bird flies with its prey.

In addition to the food above mentioned, Thrushes are partial to fruit, seeds and berries of various kinds; berries, in fact, constituting a considerable portion of their diet during hard weather, when the ground does not admit of their procuring insect food.

In the case of so familiar a bird, the nest and eggs are doubtless too well known to need description. 


\section{THE BLACKBIRD.}

TURDUS MERULA.

To those who do not happen to possess a fruitgarden, the presence of a Blackbird on the lawn and amongst the shrubs gives unqualified satisfaction. But owners of strawberry-beds think otherwise; and it is as difficult to persuade a gardener to let Blackbirds alone as it is to convince a keeper that the Kestrel and the Barn Owl do much more good than harm. Not that we mean to assert that Blackbirds do not care for strawberries, for we have too often had ocular proof to the contrary ; but we would remind the owners of fruitgardens referred to that there are other ways of saving their fruit from sable pilferers besides shooting them. Indeed a moment's reflection should convince the gardener that the sudden distribution of an ounce and a half of No. 6 shot amongst a lot 
of strawberry plants, or through a cherry tree, would cause more damage in one second than a Blackbird could effect in an afternoon. But we fear these gentry, as a rule, are not given to reflection, and are too prone to act upon a sudden impulse. It would be well if they could be persuaded to take the advice of that Scotch poet who wrote :-

"Scare, if ye will, his timid wing away,

But, O, let not the leaden viewless shower, Volleyed from flashing tube, arrest his flight, And fill his tuneful, gasping bill with blood,"

-that "orange-tawny bill" of which Shakespeare has taken note; the "golden bill" of Drayton's "woosel." In some parts of the country the Blackbird is still called "Ouzel" (evidently borrowed from the French Oisel), although this name is more commonly applied to the Ring Ouzel, Turdus torquatus.

In many respects what has been said of the Thrush applies equally well to the Blackbird-that is, as regards haunts, food, and habits; even the habit of flocking in autumn, when a partial migration takes place. On the Northumberland coast, according to Selby, vast flocks of Blackbirds make 
their appearance from more northern counties. They remain but a few days to recruit, and then resume their flight in a south-westerly direction. In Norfolk Mr. Stevenson has remarked that in autumn a migratory movement takes place with Blackbirds as well as Thrushes, and we have frequently observed the same thing in West Sussex.

In Ireland, says Mr. Blake-Knox (Zoologist, r867, p. 684), "miles of hedges may be traversed in September and October, and not one seen; but in November, when the haws are ripe, every hedge and garden is full of them, old and young. Nowhere can we go countryways but we hear their cheery cries, and I know persons who have at this season shot several dozens in a day for making pies."

From these observations made in different parts of the country, it is probable that the Blackbird is to a certain extent migratory throughout the British Islands; but although our home-bred birds may, and undoubtedly do, receive considerable accessions to their ranks during the autumn, numbers of which pass on southward, it is evident that a great many remain to spend the winter with us.

As an instance of how unsafe it is to generalise 
from observations made in a single district, we may quote a sentence from Macgillivray, who says of this bird:- "Even in severe weather in winter Blackbirds are not gregarious; and on no occasion have I seen more than three or four together, and that only for a few minutes." No doubt this was perfectly true of the locality or district in Scotland where this observation was made; but, as shown by the remarks of other naturalists above quoted, it by no means admits of general application.

On one occasion when partridge shooting early in September, in West Sussex, we were so astonished at the extraordinary number of Blackbirds which continued to rise from a field of turnips that after a bit we commenced to try and count them, and estimated that there were at least seventeen to an acre! From an examination of the stalks and under sides of the turnip-leaves, we concluded that the chief attraction for the Blackbirds there was the quantity of small meadow slugs, Limax agrestis, which abounded.

The Blackbird, like the Thrush, is very fond of the banded snails, Helix hortensis and nemoralis, and gets at them in the same way-namely, by 
knocking the shells against a stone. It takes a variety of other food, however, in addition. Macgillivray says: "Having opened five individuals, I found in the stomach of one a great quantity of seeds and husks of Graminea, including wheat and oats; in that of another, coleopterous insects; in that of a third, coleoptera and seeds of various kinds; in that of the fourth, mollusca and seeds of various kinds; in that of the fifth, seeds, mollusca, and a few grains of gravel. Earthworms, larvæ, berries, and seeds of various kinds, I have also observed in the stomachs of various individuals which I have opened."

When searching for worms upon a lawn, the attitudes which this bird assumes are very varied and graceful. The worm when discovered and drawn forth is never swallowed whole, unless a very small one, but is invariably pecked into fragments and swallowed piecemeal. In hard weather it often eats the berries of the hawthorn, which it swallows whole, and betakes itself to the rickyards, where it picks up seeds, chiefly on the ground.

The flight of the Blackbird over an open space is steady, without undulations; but along the hedges 
is wavering and fitful, and the bird suddenly darts into the place which it selects, and instantly settles. During the breeding season, as remarked by Macgillivray, its flight is peculiar; for then the female, especially, moves through the air as if by starts, giving a single flap of wing followed by a considerable interval, and then continuing its course.

In regard to its nesting, little need here be said, the bird being too well known to render any description of nest and eggs requisite. The assiduity with which both parents feed their young has been proved by the published observations of Mr. Weir, who, on watching a pair of Blackbirds for an entire day, ascertained that between 2.30 A.M. and 9 P.M. the male fed the young forty-four times and the female fed them sixty-nine times.

We may mention one curious fact with regard to the nesting perhaps not generally known-namely, that the Blackbird will occasionally pair with the Thrush. Two or three such instances have been known to occur. One is mentioned by Macgillivray (vol. ii. p. 92); another is recorded in the Magazine of Natural History (vol. vii. p. 599). In the latter 
case hybrids were produced from such a union in two successive years.

Pied and even white Blackbirds are occasionally met with; and on two occasions, in different localities, we have seen a pure albino specimen of this bird. This abnormal coloration is doubtless dependent, in a great measure, if not entirely, to the condition of health in which the individual thus affected happens to be; and it has been observed that the variation is not always permanent, for a pied bird in the course of a fresh moult frequently reassumes its normal colouring. 


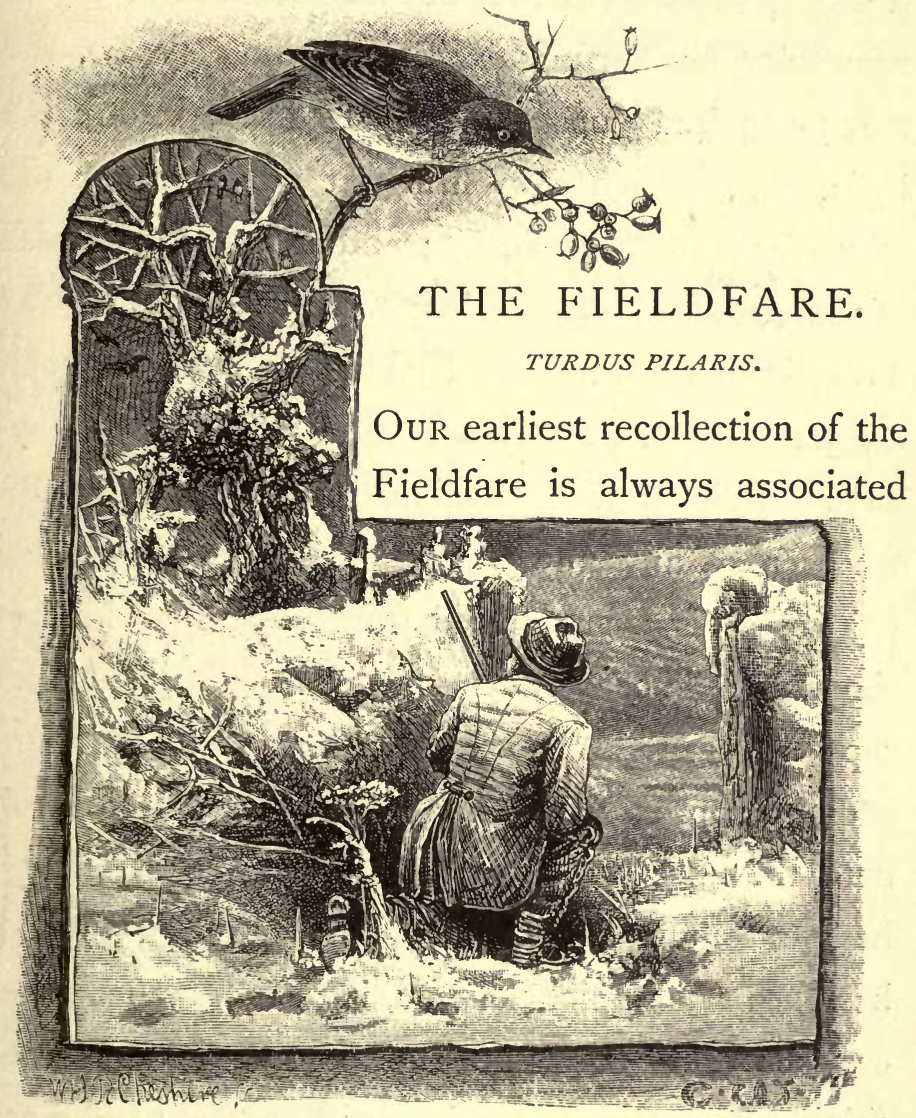

with the time when, first entrusted with a gun, we crept stealthily over the crisp snow at Christmas- 
time, and, under cover of a straggling hedge, took a "pot shot" at every "Felt" we could get near.

In this kind of shooting- " hedge-popping," call it what you will-there is at one period of our lives something wonderfully exciting. The charm of the newly-acquired gun; our intense desire to make a bag; our diffidence in firing at anything on the wing, for fear of missing it ; and the attractive size of the Fieldfare and Redwing, which "sit up well," and offer a good mark, all combine to render such an amusement, at such an age, particularly enjoyable. Indeed, we are almost inclined to doubt whether, at any after-period of life, so much real enjoyment is ever derived from any other kind of shooting. Those who have not tried it must not suppose that the sport is tame,-that the Fieldfare is easily approached, and sits quietly upon his perch until the shot brings him down. No such thing; he is uncommonly wary and suspicious, and after he has once caught sight of you, it is by no means an easy matter to get within shot of him. We used to think at one time that it could scarcely be more difficult to stalk a deer than to stalk a "Felt ;" and many a time have we crawled until our back ached, 
and followed a noisy flock from tree to tree, and from hedgerow to hedgerow, until we had wellnigh despaired of a shot. But when perchance a straggler remained behind, and his chattering note betrayed his whereabouts, we had our triumph and our reward; for we took a steady aim at him from behind a tree, and he came toppling down amid a shower of twigs and leaves.

When walking home in the twilight with a pocket full of such "game," we had leisure to speculate upon the extraordinary distance which the Fieldfare must travel to reach this country, and upon the causes which could lead to such a wonderful journey.

With us the bird is but a winter visitant, arriving in October and departing in April. Its summer haunts are in Sweden, Norway, Lapland, Poland, Prussia, Russia, and Siberia, ${ }^{1}$ where, unlike our familiar resident Thrushes, it is gregarious, and breeds in colonies.

Mr. Hewitson, writing of its habits in Norway,

${ }^{1}$ The Fieldfare, it appears, is not found in Iceland, although the Redwing is a regular migrant there. Prof. A. Newton, in BaringGould's Iceland; its Scenes and Sagas, Append. pp. 408 and 42I. 
says :" "The nests, often two hundred or more within a small space, were at various heights from the ground, from four feet to thirty or forty feet or upwards ; they were for the most part placed against the trunk of the spruce fir; some were, however, at a considerable distance from it, upon the upper surface, and towards the smaller end of the thicker branches; they resembled most nearly those of the Ring Ouzel ; the outside is composed of sticks, and coarse grass and weeds, gathered wet, matted with a small quantity of clay, and lined with a thick bed of fine dry grass."

The eggs, usually five or six in number, are "very similar to those of the Blackbird, and even more so to those of the Ring Ouzel."

Mr. Hewitson states that the Fieldfare is the most abundant bird in Norway; ${ }^{2}$ and the late $\mathrm{Mr}$. Wheelwright, better known, perhaps, by his nom de plume "The Old Bushman," has remarked that in Lapland, next to the Brambling (Fringilla montifringilla), it is the commonest bird in the forest.

1 Eggs of British Birds, i. p. 58.

2 See also Mr. Norman's "Nat. Hist. Notes in Norway," Zoologist, 1864, p. 8865 . 
Strange to say, in the latter country it appears to depart somewhat from its usual habit in nesting, for Mr. Wheelwright says : "They did not breed here in colonies; for although the nests are seldom far apart, we never found two in the same tree." 1

Some few instances are on record of the Fieldfare having remained to breed in Great Britain; but such instances are very rare, and must be looked upon as purely accidental. The counties in which nests are reported to have been found are Sutherland (St. John), Yorkshire (Y Yarrell), Kent (Yarrell), Surrey (Blyth), and Hants (Bree).

In Orkney and Shetland the Fieldfare is a regular winter visitant, and in the former island it has occasionally been known to stay during the whole year, although never found nesting there, ${ }^{2}$

As a rule the Fieldfare arrives in England during the third week of October, and generally later than the Redwing. Instances are recorded of Fieldfares having been seen in August and September; but in most cases it was found, on inquiry, that the observers had mistaken a flock of Mistletoe

1 A Spring and Summer in Lapland, p. 282.

${ }^{2}$ Baikie and Heddle, Hist. Nat. Orcadensis, I848, p. 34. 
Thrushes for the species under consideration, and doubtless this mistake has been oftentimes committed. We lately received a letter from a friend near London, informing us that a flock of Rock Thrushes (Petrocincla saxatilis) had been seen in his neighbourhood by two gentlemen of his acquaintance, one of whom was stated to be "well up in English birds and very observant." Such an interesting and at the same time startling piece of news was enough to put any ornithologist on the alert, and, notwithstanding our impression that the Rock Thrush is not gregarious, and is so extremely rare in England that only one instance of its occurrence here is recorded, we determined from curiosity to ascertain if possible what species had been mistaken for it. Accordingly, armed with our friend's letter, and furnished with the names and addresses of the observers, we called upon them in turn with a skin of the Rock Thrush in our pocket. From the descriptions which we then received of the appearance, actions, flight, and note of the birds which had been seen, there could be no sort of doubt but that the species was that of our old friend the Fieldfare, and the production of the skin of the Rock Thrush 
proved conclusively to the observers that they had been mistaken. Now, had we rested content with the assurance that a gentleman "well up in English birds" had seen the Rock Thrush, or a flock of Rock Thrushes, at such and such a place, and had we on the strength of this assurance published the fact in one or other of the natural history journals, it is difficult to say what amount of mischief might not have resulted from supplying such data for future ornithologists to found conclusions on. Those who interest themselves in collecting and publishing accounts of rare birds, cannot be too careful in first ascertaining that the evidence upon which their statements are founded is incontestable.

But to return to the Fieldfare: few birds seem to attract so much attention at the season of their arrival in this country. During the month of November we see every year numberless short paragraphs in the Field, the Zoologist, and other natural history journals, in which the "first appearance" of this species in various localities is duly chronicled and commented on. For six months in the year the Fieldfare is generally dispersed, and 
tolerably common in most parts of the country. Towards the end of April it disappears, retiring northward to its summer haunts. ${ }^{1}$

During its stay with us it frequents the open country, feeding on the small meadow slug (Limax agrestis), of which it seems particularly fond, varying its diet with worms and beetles. As the weather becomes colder, and the ground harder, it resorts to the hedgerows to devour the fruits of the dogrose and whitethorn, commonly known as "heps and haws," and in such situations, traces of its visits are always to be found in the bright red droppings which are noticeable on the ground hard by. The berries of the ivy and rowan-tree (Pyrus aucuparia), are also eagerly devoured, and in the absence or scarcity of such food, Fieldfares have been observed to attack turnips, digging at the exposed portion of the roots, and chipping off small pieces, which they swallowed with avidity. Several birds which were shot while thus engaged, were found to have the stomach completely filled with such chips. It is probably not often that the Fieldfare is driven to

1 We once shot one out of a flock on the 4 th May, but consider this a late date at which to find the bird here. 
such extremities, and compelled to steal turnips like a hungry vagabond. The practice no doubt is a mischievous one, as the farmers will tell us ; for the water lodging in the holes which are pecked by the birds, the roots are rotted, and the crop is seriously impoverished,

We can make allowances, however, for such damage, when we consider what our own feelings would be under such hungry circumstances. 


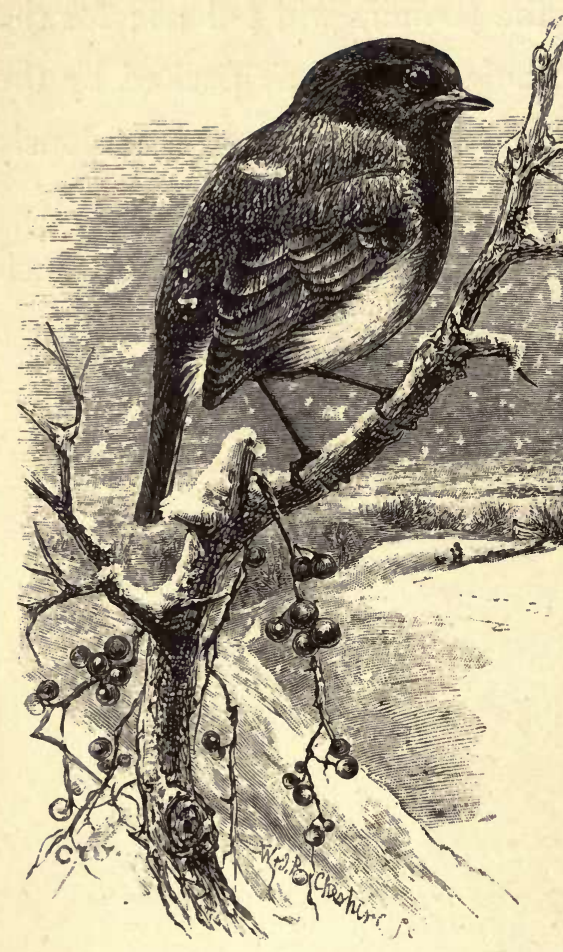

\section{THE ROBIN.}

ERITHACUS RUBECULA.

LATE in autumn, when the leaves are strewn, and hedges have begun to look bare, the Robin comes prominently into view. We have hardly noticed him all the summer, for he has kept out of sight while engaged in nesting operations; and his not over-loud notes have been almost drowned by the daily chorus of more favoured songsters. Most of 
these are now silent; many have left our shores for warmer winter-quarters. The Thrush still holds his own; the Blackbird, Chaffinch, and Wren warble at intervals-by fits and starts, as it were. But the Lark seldom sings so late in the year, and the monotonous notes of the Common Bunting and the Yellowhammer are heard no more. The Nightingale has fled; so also have the Blackcap, Tree Pipit, Whitethroat, and Garden Warbler. We miss the continuous trill of the Grasshopper Warbler, and the noisy, babbling, rapid notes of the Sedgebirds. The feathered choir, indeed, is deprived of its leading vocalists, and only the second-rate artistes remain behind to attract the notice which was denied them in the presence of more accomplished rivals.

It is at this period of the year that the song of the Robin strikes us more particularly than at any other season, although it must be admitted that, from charitable motives, this familiar little bird claims a large share of our attention at Christmas.

Those who have listened attentively to the song of the Robin at this season of the year will be prepared to admit that there is something plaintive, 
something of sadness in the strain. It seems to tell us that the beauty of the year is gone; that flowers have faded, and leaves have dropped; while the singer mourns for Philomel, who has deserted the grove. The effect produced upon the mind has been happily expressed by Cowper, in his "Winter's Walk at Noon":-

"No noise is here, or none that hinders thought ;

The Redbreast warbles still, but is content

With slender notes and more than half suppress'd ;

Pleased with his solitude, and flitting light

From spray to spray where'er he rests, he shakes

From many a twig the pendant drops of ice,

That tinkle in the wither'd leaves below.

Stillness accompanied with sounds so soft

Charms more than silence."

The familiar habits of this bird have in most countries obtained for it familiar names. Thus, about Bornholm it is called "Tommi Liden ;" in Norway, "Peter Rosinad;" in Germany, "Thomas Geirdner;" and with us, "Robin Redbreast." Indeed, the fearlessness which it displays, and the confidence which it exhibits in man, have rendered it everywhere a general favourite, and have secured for it a protection accorded to few other birds.

Numerous are the anecdotes which have been 
related of Robins, and numerous the descriptions of curious nesting-places recorded. ${ }^{1}$ Many such will doubtless occur to every reader of these lines.

An old name for the Redbreast is "Ruddock," the meaning of which is illustrated in the word "ruddy," and the bird is still known by this name in some parts of England. Spenser writes of "the ruddock warbling soft" (Epithalamium, i. 82), and Shakespeare has thus named it in one of his most beautiful passages :-

"With fairest flowers,

Whilst summer lasts, and I live here, Fidele, I'll sweeten thy sad grave: thou shalt not lack The flower that's like thy face, pale primrose ; nor The azur'd harebell, like thy veins; no, nor The leaf of eglantine, whom not to slander, Outsweeten'd not thy breath : the ruddock would With charitable bill-O bill sore shaming Those rich-left heirs that let their fathers lie Without a monument !-bring thee all this;

Yea, and furr'd moss besides, when flowers are none, To winter-ground thy corse."

Cymbeline, Act iv., sc. 2.

Bishop Percy asks: "Is this an allusion to the Babes in the Wood, or was the notion of the Redbreast covering dead bodies general before the

${ }^{1}$ See Bishop Stanley's Familiar History of Birds, p. 223. 
writing of that ballad ?" Mr. Knight says : "There is no doubt that it was an old popular belief, and the notion has been found in an earlier book of natural history."

John Webster, writing in 1638 , says :-

"Call for the Robin Redbreast and the Wren,

Since o'er shady groves they hover,

And with leaves and flowers do cover

The friendless bodies of unburied men."

Izaak Walton, too, in his Compleat Angler, 1653 , speaks of "the honest robin that loves mankind both alive and dead." Possibly Shakespeare intended only to refer to the ancient and beautiful custom of strewing the grave with flowers.

The Robin and the Wren have for centuries, from some unexplained cause, been always associated together, as in the lines above quoted. In many parts of England the country people regard them as male and female of one species, and support their assertion with an old couplet-

"The Robin Redbreast and the Wren Are God Almighty's cock and hen."

This fanciful association is probably only the result of imperfect observation of the structure and habits 
of the two birds. They affect similar haunts, and often select similar situations for their nests. They are loudest in song when other birds have ceased, and both seem to place themselves directly under the protection of man, there being hardly a woodstack or a rickyard in the country that cannot produce its pair of Robins and its pair of Wrens. This is especially the case in winter, when a sudden advent of cold, and especially a fall of snow, drives them towards the homesteads for shelter and greater certainty of food.

The food of the Robin consists chiefly of insects, and especially of spiders, which are sought for under dead leaves, amongst moss on the ground, or in the crevices of trees and old walls. It also takes worms, drawing them forth after the manner of the Thrush, and beating them on the ground before swallowing them. The only fruit we have seen it touch is the raspberry, but other observers have noted its partiality for red currants, and it is very fond of the berries of the Nightshade (Solanum dulcamara.) In winter, as every one knows, when its natural food fails, it will readily take scraps of all kinds that are thrown to it. 
It is an early breeder, and, considering its size, makes rather a large nest. This is composed of moss, leaves, and grass, lined with horse-hair or cowhair and a few feathers, and is generally placed on or near the ground upon some hedge-bank, or against an ivy-covered wall. The eggs, usually five or six in

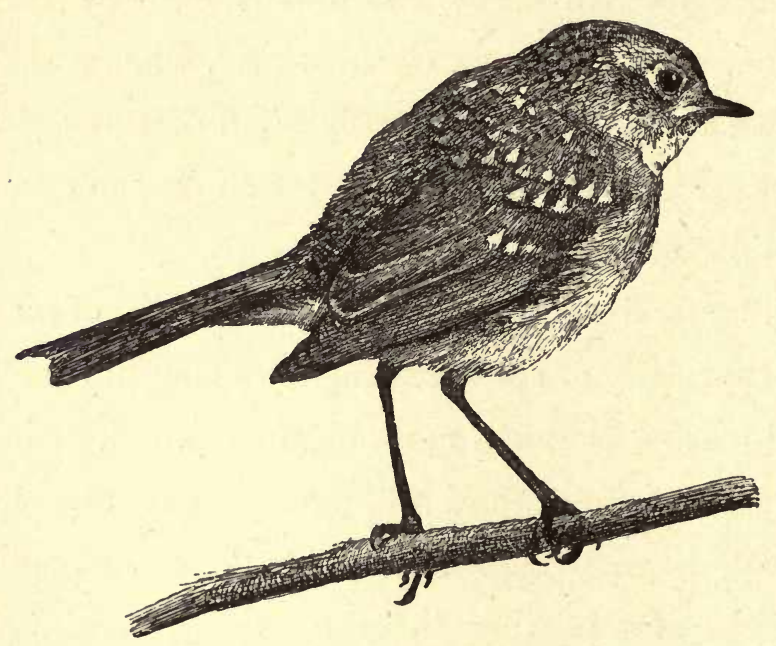

YOUNG ROBIN.

number, are white, irregularly marked towards the larger end with rust-coloured spots and blotches. The young in their first plumage are spotted, as shown in the accompanying vignette. During the breeding season cock Robins are very pugnacious, not only driving away all intruders from the nest, 
but sometimes engaging in prolonged and mortal conflict with their own species. Although more tolerant of cold than most birds of its size, the Redbreast often succumbs during heavy snow, and there must be few who have not gazed admiringly, and yet regretfully, on the lifeless form of a dead Robin, picked up on the snow, perhaps, or brought in by a cat!

Was it not Rogers who wrote this pretty epitaph on a Robin Redbreast?-

" Tread lightly here, for here, 'tis said,

When piping winds are hush'd around,

A small note wakes from underground, Where now his tiny bones are laid;

No more in lone and leafless groves, With ruffled wings and faded breast,

His friendless, homeless spirit roves;-

Gone to the world where birds are blest,

Where never cat glides o'er the green,

Or schoolboy's giant form is seen,

But love and gay and smiling spring

Inspire their little souls to sing." 


\section{THE NIGHTINGALE.}

PHILOMELA LUSCINIA.

Amongst all the birds of song the Nightingale by common consent takes precedence. Few species have attracted greater attention in the countries where it is known, and poets and naturalists have been alike eloquent in its praise.

It is popularly, but erroneously, believed that the Nightingale warbles only at eve, perhaps because amidst the general chorus by day its song is less remarked. But that it sings constantly by day is a fact of which we have had repeated proof. Nor is it by any means the only bird which is heard at night. We have frequently listened to the Thrush, Sky Lark, Wood Lark, Sedge Warbler, Grasshopper Warbler, long after sunset, and have heard the Cuckoo and the Landrail just before midnight.

It is curious how few of those who profess a love for song-birds have a sufficiently good ear to 
distinguish a song unless they can see the author of it. Hence they often listen in the early spring to the notes of the Thrush, and express their conviction that they have heard the Nightingale long before the usual time of its arrival in this country.

Many poets have perpetuated the odd belief that the mournful notes of the Nightingale are caused by the bird leaning against a thorn to sing! Shakespeare, for example, in his Passionate Pilgrim, says-

" Everything did banish moan, Save the Nightingale alone; She, poor bird, as all forlorn, Lean'd her breast up-till a thorn; And there sung the dolefull'st ditty That to hear it was great pity."

These lines, by the way, although generally attributed to Shakespeare, and included in most editions of his poems, were written, it is said, by Richard Barnefield in I598, and published by him in a work entitled Poems in Divers Humours. ${ }^{1}$ Shakespeare's Lucrece, however, invoking Philomel, says-

"And whiles against a thorn thou bear'st thy part To keep thy sharp woes waking."

${ }^{1}$ See Ellis's Specimens of the Early English Poets, vol. ii. p. 356. 
Fletcher speaks of-

" The bird forlorn,

That singeth with her breast against a thorn."

And Pomfret, writing towards the close of the seventeenth century, says-

"The first music of the grove we owe To mourning Philomel's harmonious woe; And while her grief in charming notes express'd, A thorny bramble pricks her tender breast."

The origin of such an odd notion it is not easy to ascertain; but probably Sir Thomas Browne was not far from the truth when he pointed to the fact that the Nightingale frequents thorny copses, and builds her nest amongst brambles on the ground. He inquires "whether it be any more than that she placeth some prickles on the outside of her nest, or roosteth in thorny, prickly places, where serpents may least approach her ?"1

In an article upon this subject published in The Zoologist for 1862 (p. 8029), the Rev. A. C. Smith, Vicar of Calne, Wilts, has narrated the discovery on two occasions of a strong thorn projecting upwards in the centre of a Nightingale's nest. It cannot

I Sir Thomas Browne's Works, Wilkin's ed., vol ii. p. 537. 


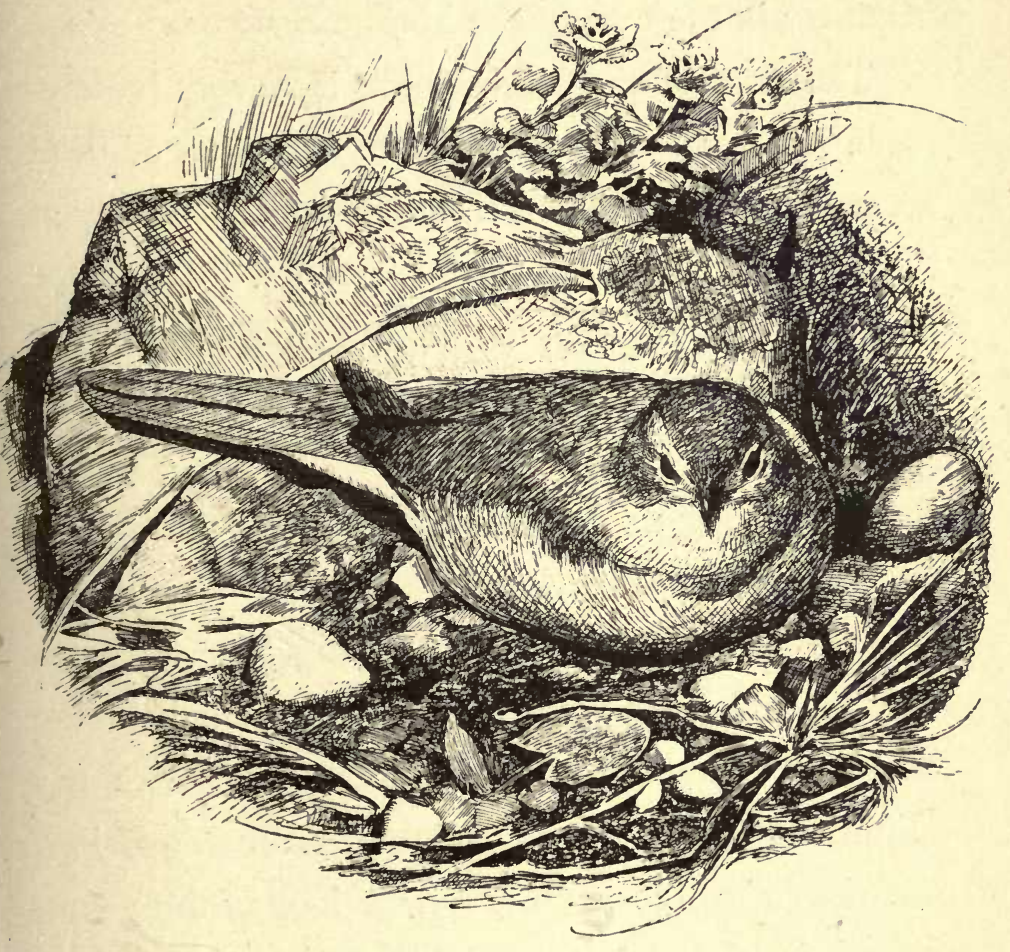

THE NIGHTINGAIE. 
be doubted, however, that this was the result of accident rather than design; and Hewitson, in his Eggs of British Birds, has adduced two similar instances in the case of the Hedge Sparrow.

The nest of the Nightingale is a very looselymade structure, composed for the most part of dead leaves, and placed upon a hedge-bank, generally at the root of some stout shrub or thorn. The eggs, usually five in number, are, like the bird itself, of a plain olive-brown colour.

The young Nightingales are spotted like young Robins, having the feathers of the upper portions of the plumage tipped with buff colour.

In some respects the Nightingale assimilates very much in habits to the Robin ; and advantage has been taken of this, in localities where the Nightingale is unknown, to introduce its eggs into the nests of Robins, with a view to having the young reared in the neighbourhood, and so induced to return to it. But although, as regards hatching and rearing, the plan was successful, the birds did not return to the place of their birth.

For some inexplicable reason, a limit appears to be set to the migration of the Nightingale, which 
has no parallel in the case of other migrants. The boundary line, over which it seldom, if ever, flies, excludes it from Cornwall, West Devon, part of Somerset, Gloucester, and Hereford ; the whole of Wales (à fortiori from Ireland), part of Shropshire, the whole of Cheshire, Westmoreland, Cumberland, Durham, and Northumberland. It is true that it has been reported to have been heard and seen in Wales, Cumberland, and even in Midlothian; but even if they could be relied on in every case, which is doubtful, these instances can only be regarded as exceptional. In those counties only to the east of the line indicated can the bird be considered a regular summer visitant. Blyth expressed the opinion that the Nightingale migrates almost due north and south, deviating but a very little indeed either to the right or left. In a note to his edition of White's Selborne, p. I41, he says- "There are none in Brittany, nor in the Channel Islands, and the most westward of them probably cross the Channel at Cape la Hogue, arriving on the coast of Dorsetshire, and thence apparently proceeding northwards rather than proceeding towards the west; so that they are only known as accidental 
stragglers a little beyond the third degree of western longitude." He was mistaken, however, in supposing that the Nightingale is unknown in Brittany. Mr. H. V. Wilson informs us that when travelling one night in the month of May from Nantes to Chateaubriant, on nearing Chateaubriant the conveyance was stopped at the foot of a steep hill for all to walk up. There was a forest on each side of the road; it was a dark, still night, and both sides of the road amongst the trees seemed to be alive with Nightingales singing their loudest. ${ }^{1}$

The Nightingale arrives in England generally about the second week in April, the cock birds invariably preceding the hens by several days. On the arrival of the latter, the former soon pair and assist in building, during which time, and while the hens are sitting, they are in full song. When the young are hatched the male birds leave off singing, and busy themselves in bringing food to the nest.

The song usually ceases before the end of the first week in June. Occasionally, however, we have heard a Nightingale sing on throughout June, but accounted for this by supposing that the nest

${ }_{1}^{1}$ The Zoologist, 1877, p. 259. 
had been robbed, and that the cock was singing while the hen hatched a second brood.

As autumn approaches the Nightingale moves southwards towards the Mediterranean, and spends the winter months in North Africa, Egypt, Asia Minor, Nubia, and Abyssinia. So far as at present ascertained, it has not been met with further eastwards than Kasbin, in Persia, as remarked by Professor Newton, who, in his edition of Yarrell's British Birds, has given some interesting details of its geographical distribution. 


\section{THE BLACKCAP.}

SYLVIA ATRICAPILLA.

Every lover of birds, on hearing for the first time the exquisite song of this bird, must have experienced a curiosity to discover the author of it. Arriving in this country about the middle of April, it is in full song about the end of the month, pouring forth strains which are only equalled by those of the Nightingale and Garden Warbler.

Though its colours are plain and uniform, the black crown of the male (which is brown in the female) and a brisk, lively expression give it an attractive appearance, although, from its shy disposition, it is oftener heard than seen. It loves the retirement of the woods, and the concealment afforded by thick and tangled undergrowth in unfrequented copses.

In the neighbourhood of the metropolis it is 
well known to the birdcatchers, and is a frequent visitor to the large market-gardens of Kent, Surrey, and Middlesex, where, candour compels us to say, its chief attraction is fruit. Upon this the parent birds live to a great extent; and, after bringing up their young upon various kinds of insects which infest fruit-trees, thereby making some amends for their depredations, they introduce their progeny at length to the more palatable pulp upon which they themselves fare so sumptuously. They are particularly fond of red currants, which they swallow whole, and with much apparent satisfaction. Raspberries they are unable to swallow, except piecemeal, and their bills may often be seen stained with the juice of this fruit.

Perhaps no better place could be selected for studying the actions of the Blackcap than amongst the raspberry bushes, for so intent is the bird on pilfering the fruit that it then admits of a much nearer approach than at any other period of its stay with us. If pursued it flits from bush to bush, but seldom takes a long flight, and, although extremely lively and agile, it seeks to hide itself from observation, and is in all respects a solitary bird, more than 
two adult individuals being seldom or never seen together.

Its song is continued from the time of its arrival until the end of June, and has been well described by Sweet in his British Warblers. He says"The song of the Blackcap is very loud and agreeable, and it has a great variety of notes; it is also a real mocking-bird, and will catch the notes of any bird that it chances to hear sing. I have heard it imitate the Nightingale so exactly that it has deceived me; also the Blackbird, Thrush, and the Greater Pettychaps [the Garden Warbler], all of which it imitates so much in its voice that it is almost impossible to detect it, except when it runs from one into the other, or shows itself in the open part of a tree."

As a cage-bird it is most lively and interesting, and sings as unceasingly as in its natural state. Nor is it difficult to manage. It may be fed upon bruised hemp-seed and bread as its ordinary fare, but it is impossible to keep it in health for any length of time without giving it a regular supply of small worms, insects, caterpillars, and grubs of various kinds. In summer it should also have 
cherries, raspberries, and currants, and in winter a piece of over-ripe apple or pear, or some roasted apple. With this treatment it will be both cheerful and contented, singing nearly the whole year, except, of course, at the period of moulting, when all birds lose their song.

The nest, although very slight in structure, is firmly and compactly put together, and much resembles that of the Garden Warbler. It is usually placed in the fork of some shrub or bush at no great height from the ground, and is composed of dry goose-grass and a little moss, lined with fine fibrous roots and a little horse-hair.

The eggs, usually five in number, are white clouded with pale brown, and sparsely spotted towards the larger end with black dots. They closely resemble the eggs of the Garden Warbler, but differ in being smaller, and as a rule of a warmer tint; the pink or reddish-brown colour, with which the eggs of the Blackcap are often suffused, is not found in those of its congener.

Both sexes take their turn at incubation, relieving one another to feed; but the male will often 
feed his partner on the nest, and then sit and sing to her. They are very jealous of any approach to, or interference with, their nest, and will desert it on the slightest provocation.

In discovering their insect-prey they exhibit much adroitness and activity, searching every branch and crevice with great minuteness and rapidity, and threading the interstices of the thickest underwood with the greatest ease and celerity.

However much observers may be deceived by song, there is no mistaking either sex of the Blackcap as soon as the bird comes in view. The black crown of the male and the brown cap of the female suffice to distinguish the species amongst every other of our summer migratory birds. There is something very peculiar, too, about the half-hopping, halfcreeping motions of these warblers, which distinguishes them at once from other small birds frequenting the same haunts.

The males invariably arrive some days before the females; but both sexes seem to leave this country much about the same time-that is, early in September.

Many instances, however, are on record of 
Blackcaps having remained with us throughout the winter; and this has been noticed as particularly the case in Ireland. It is rather singular that Yarrell, in referring to the sister isle, says that the Blackcap "has been taken once at least in the North of Ireland," as if he were of opinion that its occurrence there was doubtful, or at least extremely rare. Thompson, in his excellent Natural History of Ireland, vol. i. p. 183, notices the Blackcap as a regular summer visitant there; but he adds that it must be considered very local.

In Scotland it is considered rare, being confined chiefly to the south; but since the observations were published from which these remarks are drawn, considerable changes seem to have taken place in the local distribution of many species of birds. This is notably the case with the Blackcap and Garden Warbler, both of which have followed cultivation, and are now found commonly in localities where five-and-twenty years ago they were either unknown or stated to be extremely rare. 


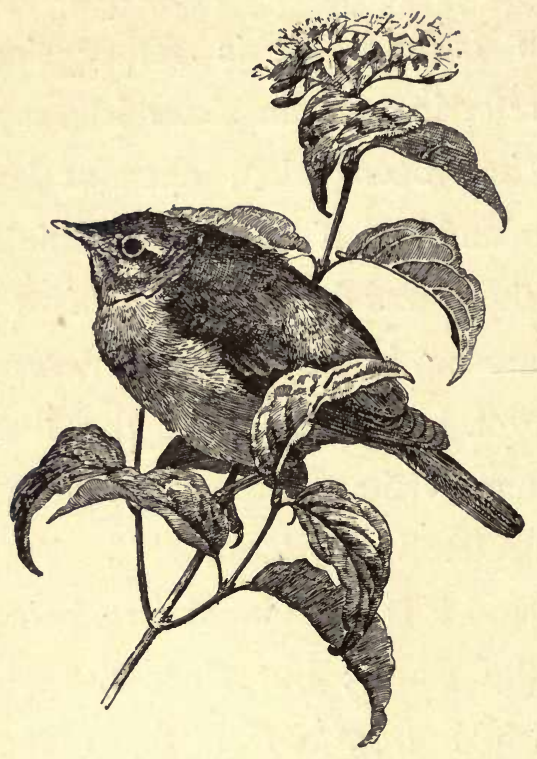

YOUNG GARDEN WARBLER.

\section{THE GARDEN WARBLER.}

SYLVIA HORTENSIS.

UNDER the most favourable circumstances of wind and weather this pretty summer visitant seldom makes its appearance in England before the end of April, being a late comer in comparison with many of our summer birds.

In outward appearance both sexes are alike; 
but it has been ascertained by careful observers, who have dissected specimens, that the males always arrive in this country before the females. The same has been observed of the Nightingale, Blackcap, and some other species.

To some of the older authors, as Willughby, Pennant, and Montagu, this bird was known as the Greater Pettychaps, while they bestowed the name of Lesser Pettychaps-presumably from its resemblance in miniature - to the Chiffchaff. The Pettychaps of Gilbert White, however, referred to in his fifty-seventh Letter to Daines Barrington, is evidently, from his description of its appearance and habits, not the Garden Warbler, but the Lesser Whitethroat.

Throughout England the Garden Warbler is generally distributed, but seems to be commoner in the south and south-east; towards the west it is much rarer. Mr. A. G. More, in his essay on the "Distribution of Birds in Great Britain during the Nesting Season" (Ibis, I865, p. 25), refers to it as scarce in Cornwall and Pembrokeshire, and absent from Wales. The late Mr. Rodd, however, in his recently-published Birds of Cornwall, includes 
it as a summer visitant to the eastern portion of that county, and observes that it breeds annually in the woods at Trebartha, Northhill. He only once met with it at Penzance, but it has several times been observed at Scilly with other migratory warblers in autumn. Dr. Bullmore, also, in his Cornish Fauna, p. I7, confirms Mr. Rodd's statement that it is a summer visitant to East Cornwall.

Its alleged absence from Wales is remarkable, if true, for it has been met with in various parts of Ireland, as, for example, in the counties of Dublin, Wicklow, Fermanagh, Tipperary, and Cork. We are inclined to think that this bird will be found to be a regular summer visitant to suitable localities throughout Wales, and that the reason of its not having been yet observed there is that the number of resident naturalists there is so small in comparison with other parts of Great Britain that it has escaped notice.

The limit of the Garden Warbler's range northwards in the British Islands has not been satisfactorily ascertained. That it is found in many parts of the South of Scotland we know from the observa- 
tions of Macgillivray and Sir William Jardine; but we have yet to learn whether it penetrates to the Highlands, or visits the Hebrides. According to Selby it is found throughout the greater part of Scotland; but Mr. Robert Gray is disposed to think that it is not commonly distributed. It is, as he says, very difficult to judge of the comparative numbers of so shy a bird, as it is even less frequently noticed, save by the patient observer, than some other species of greater rarity. "In the sheltered and wooded districts of the midland and southern counties," he adds, "it is one of the most attractive songsters, tuning its loud and gleeful pipe on the top of some fruit tree an hour or two after daybreak, and again about dusk. These love-notes, however, are not of long continuance, for the bird becomes silent after the young are hatched, unless a second brood is reared, when the same wild, yet mellow, Blackbirdlike song is again for a short time heard." Mr. Sinclair has observed the Garden Warbler at Inverkip, in Renfrewshire, where the richly-wooded preserves afford it a constant shelter during its summer sojourn.

In Shetland, according to the late Dr. Saxby, 
it is a rare autumn visitor, usually occurring in September. By exercising great caution he has sometimes approached within a few feet of the bird, and watched it picking the green Aphides from the sycamore leaves. In Orkney it seems to have been not hitherto observed.

In habits the Garden Warbler closely resembles other members of the genus Sylvia. Shy and restless, it differs from the Blackcap in its inferior powers of song, and from the Whitethroats in being less garrulous. It is nevertheless a good songster, and will sometimes sit in the midst of a thick bush in the evening, like a Nightingale, and maintain a continued warble, for several minutes without a pause. Its song is somewhat irregular, both in tune and time, but it is wonderfully mellow for so small a bird. It sometimes commences its song like a Blackbird, but always ends with its own. In some of its actions it resembles the Willow Wren, for it seems constantly in motion, hopping from bough to bough in search of insects, and singing at intervals. It is very partial to fruit of all kinds, but at the same time destroys vast numbers of caterpillars, spiders, and Aphides. It will dart into the air and 
catch insects after the manner of a Flycatcher, often taking its stand upon a dahlia stake, or some other "coign of 'vantage," watching for its prey, darting aloft with inconceivable rapidity, with its bill upwards, catching the fly with a loud snap of the bill, and immediately returning to its station, again and again to renew the same process with similar success.

The nest, which is almost invariably made of the goose-grass, Galium aparine, mixed with a little moss, and lined with very fine fibres and horse-hair, is as slight a structure as that of the Blackcap, to which it bears a considerable resemblance. It is generally built in a low bush or thick brake, sometimes even on the ground amongst nettles and weeds, and occasionally in a forked branch four or five feet from the ground, being fastened to the branch with cocoons, spiders' webs, or some such substance. The eggs are four or five in number, of a rusty white colour, spotted, or rather blotched, with darker brown, chiefly towards the larger end, and closely resemble those of the Blackcap, from which they are not easily distinguished.

The young birds quit the nest rather early, 
especially on the approach of an intruder, and so suddenly and simultaneously will the whole brood tumble out and conceal themselves, that it is very difficult to discover them, for they will squat down and lie perfectly quiet amongst the weeds and long grass, just like young Partridges, until the intruder has left the spot.

The sexes differ very slightly in appearance, but the young of the year have a more yellowish hue than their parents. Blyth, who had good opportunity for observing the habits of this bird, thought that both male and female take their turn on the nest. 


\section{THE WHITETHROAT.}

SYLVIA CINEREA.

Country lads call this bird the "Nettle-creeper," from its frequenting overgrown ditches and hedgebanks where nettles are plentiful, amongst the stems of which it builds its nest. "Whitethroat" and "Peggy Whitethroat" are equally familiar names, the former of which often bears the prefix "Common" to distinguish it from the so-called "Lesser Whitethroat" Sylvia curruca (Linnæus), a rarer, or at least a more local, species.

Both are summer visitants to the British Islands; and, although one is called "Greater" and the other "Lesser," there is really very little difference between them in point of size. Hence one reason, probably, why they are so frequently confounded. The respective measurements of the two species are as follows :- 
Total length. Wing. Tarsus.

Greater Whitethroat $\quad 5.5$ in. $\quad 2.9$ in. 0.8 in.

Lesser Whitethroat . $\quad 5^{\circ} 2 \mathrm{in.} \quad 2^{\cdot} 5 \mathrm{in.} \quad 0^{\circ} \mathrm{im}$.

Independently, however, of its slightly smaller size, the Lesser Whitethroat may be distinguished by its black ear-coverts, and by the absence of the pale rufous edgings to the secondaries, which are so conspicuous in the commoner species. The legs also are slate-coloured instead of yellowish brown.

The subject of the present notice comes to us about the third week in April, when no one can walk along a country lane without being reminded at every fifty yards of the presence of this demonstrative little bird. With crest-feathers erect and half-extended wings it bustles in and out, gesticulating loudly, and seems to live in a perpetual state of excitement. It sings a good deal on the wing, sometimes returning to the branch it has just left, after the manner of a Tree Pipit, sometimes realighting elsewhere. The song, which is commenced on arrival, generally ceases early in the month of July.

Its habits, and the "grotesquely earnest appearance," as Thompson calls it, which the erected 
crest-feathers and distended throat impart when singing, make this bird one of the most noticeable of the migratory warblers. It seems to prefer the tallest and thickest hedgerows where there are plenty of brambles and briars, and ditches which are clothed with weeds and nettles. It does not keep, however, to the fields and lanes, but visits gardens and orchards in company with its young to pilfer currants, raspberries, and other fruit, when ripe. It is especially fond of the green Aphis, and the caterpillars to be found on the currant bushes are favourite morsels with this bird: hence we should not forget that if it takes a few currants it is also the means of saving a good many.

On the arrival of the hen birds-which takes place ten or twelve days after the appearance of the other sex - the males, which had before skulked about amongst the hedgerows and low brushwood, may be seen perched on the topmost sprays, giving rapid utterance to their garrulous song, and occasionally rising into the air with a curious jerky flight while pouring forth an accompaniment of equally jerky notes.

Though inferior to the rich and varied strains of 
the Blackcap and Garden Warbler, the song of the Whitethroat is very pleasing in its way, and by no means monotonous. It may be heard from morning till night, and even during the heat of the day, when most birds are silent.

Having selected a site for its nest, the Whitethroat displays the most wonderful energy and activity in collecting materials for it, and the rapidity with which it constructs it is surprising. It is generally placed near the ground, amongst nettles, long grass, or tall weeds, and is constructed of dry grass-stems and horse-hair, often so slightly interwoven that the eggs may be seen through the sides of the nest. It is, nevertheless, tolerably firm, and must be pretty strong to bear the weight of the young when hatched, and the parent birds as they alight to feed them.

Occasionally the nest may be found in a bramble, and even in a hedgerow; and Mr. M. S. Rickards, in The Zoologist for 1875 , has recorded his discovery of a Whitethroat's nest at the extreme top of a whitethorn bush, fully twelve feet from the ground, -a most unusual height, the nest being rarely, if ever, placed out of reach. 
The eggs, usually five in number, are minutely speckled all over with ash-brown or ash-green, and spotted at the larger end with gray. Two broods are commonly reared in a season. The young birds have a light-coloured space between the bill and the eye; the irides are yellowish brown, and the outer tail-feathers tinged with rufous.

We have watched an old Whitethroat bringing food to its young, and have been surprised to see in how short a space of time it contrived to find food and return to the nest. In ridding the hedges of the swarms of caterpillars which infest them in spring, the Whitethroat certainly does good service, and in this respect makes some amends for the currants and raspberries which it takes later in the summer.

It is generally distributed throughout the British Islands; and in Ireland, where the Lesser Whitethroat is unknown, it is as common as in England.

The Lesser Whitethroat is much more local, being rare in Scotland, as well as in the West of England and in Wales, although this reported scarcity, as we have hinted in regard to some other species, may be owing not to the absence of 
the bird, but to the paucity of competent observers in the districts referred to.

Notwithstanding its delicate form and apparently feeble flight, its ability to travel long distances without resting is proved by its having been seen to alight on vessels in the Mediterranean, even when upwards of sixty miles from land.

In haunts, habits, and mode of nesting, the two species of Whitethroats are very similar, so that what has been said of one will apply almost equally well to the other. Both arrive also about the same time, namely, the third week in April; and by the end of August, when the young are strong enough to shift for themselves, they depart again southward.

Thus year by year do these tiny warblers, with others of their kind, make their way to our shores to pass the summer with us, gladdening us with their songs, and contributing, after their own fashion, to our good. By what curious instinct impelled, and by what means they contrive to find their way, are problems which ornithologists have yet to solve. 


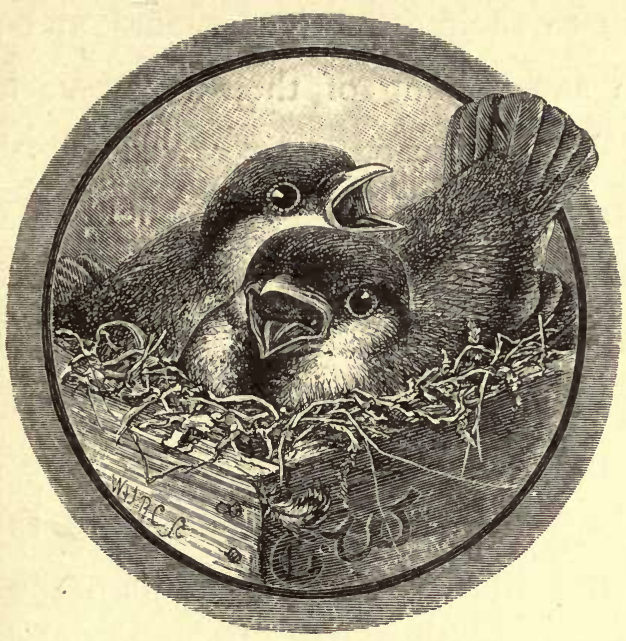

YOUNG TITMICE.

\section{THE GREAT TITMOUSE.}

PARUS MAJOR.

Admirably adapted in structure for the life they have to lead, the Tits may be regarded as amongst the most noteworthy of the smaller woodland birds. Their hard and somewhat conical bills indicate their seed-eating propensity, although, as we shall see later, they prey largely at certain seasons upon insects; while their strong feet and curved claws 
enable them to hold on in any position while searching for their food, whatever it may be.

Owing to their attractive colours and sociable habits, to say nothing of their noisy vociferation, they can hardly escape notice even by the least observant. Nor need we go far afield to discover one or more of the family. At certain seasons of the year, especially, they may be found in close proximity to our dwellings; and two of the species, at least, are regular visitors to our London gardens during the winter months. These are the Great Tit and the Blue Tit; and although the smokebegrimed trees of the metropolis sadly sully the pale yellows and delicate blues of their soft plumage, they appear as lively and careless when surrounded by bricks and mortar as when flitting from tree to tree in the fresh larch woods.

All the species of Parus are resident with us throughout the year, although they are not all equally common, or to be met with in the same localities. One at least, the Crested Titmouse, is singularly restricted in its distribution, as we shall presently see; while another, the Marsh Titmouse, must be regarded as somewhat local in its haunts. 
The cause of this partial distribution is not easy to determine, although it is probably to be explained by the presence or absence of certain food which is more or less necessary for the bird's existence.

To see the Great Titmouse at his best we should look out for him in spring, when he has assumed his nuptial plumage, and when his bright colours are seen to great advantage amongst the young leaves. $\mathrm{He}$ is then busy looking for a nesting-place, which is generally a hole in a tree, or a crevice in some old wall. A quantity of moss is carried in with strips of soft bark, and sometimes fills up a considerable portion of the cavity. Next comes a layer of cow-hair (in one particular park we have found deer-hair used for the purpose), and this is pressed down so as to form a soft yet firm platform, upon which the eggs are laid amongst a few feathers.

When quite fresh the eggs, usually six or seven in number, are of a delicate pink colour, owing to the transparency of the white shell allowing the yolk to be faintly seen through, while the larger end is profusely spotted with red. This delicate appearance passes off as soon as the eggs are incubated, as 


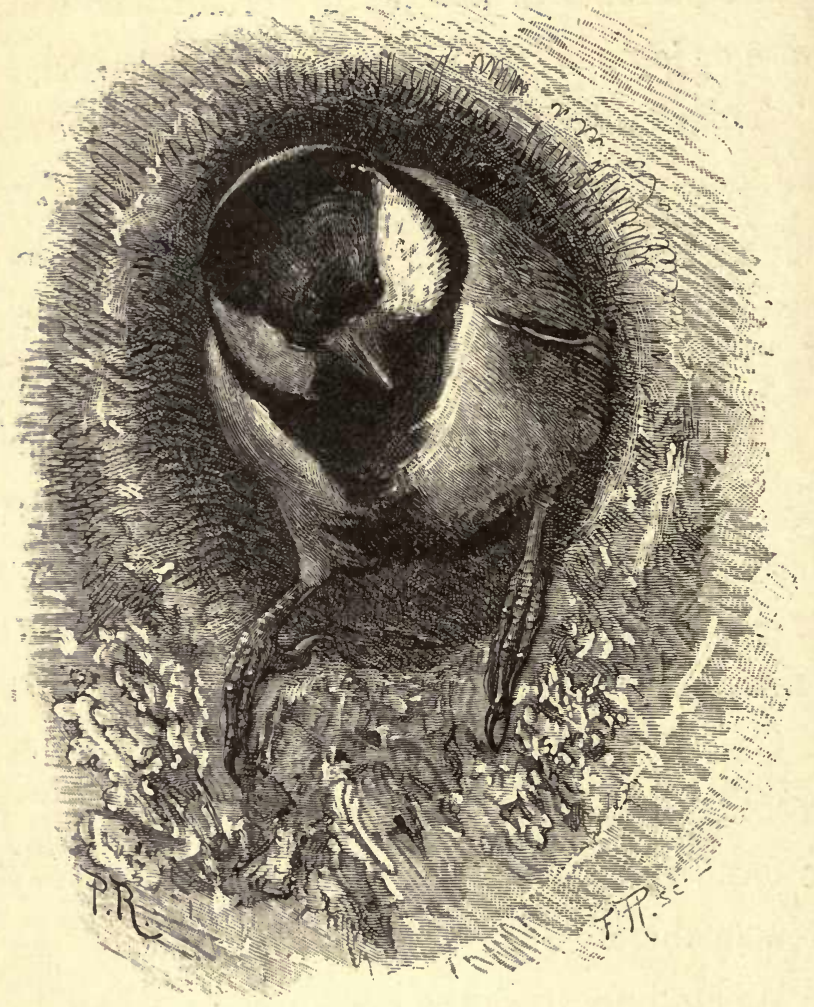

GREAT TITMOUSE. 
it does also when they are blown. It is often difficult to distinguish them from eggs of the Nuthatch, which they closely resemble both in size and colour. Indeed the birds themselves have considerable affinity, as shown by their structure, and particularly by the form of the bill.

Macgillivray has pointed out that in certain respects the Tits are allied to the Jays, not only in structure, but also in some of their habits. The Great Titmouse, being the largest of the genus, exhibits this relationship in a more remarkable degree than the others.

It is in a manner omnivorous, for, not content with seeds, insects, and larvæ, it eats the flesh of birds or small mammals; and, according to many respectable writers, sometimes attacks small or young birds, and splits their skull with its bill, picking out and devouring the brains. Seeds of cereal plants and others it breaks by repeated strokes of the bill. We have often watched a Great Tit extracting the kernel of the beech-mast, while it steadied it by holding it under one or both feet. We have also observed this bird alight upon a ripening walnut, and with repeated strokes detach 
it from the stalk, but never saw it profit by its success in following the nut to the ground and endeavouring to extract the kernel, which in the soft condition of a new walnut would not seem difficult. But possibly the bird's aim was to get at some lurking insect in the softer portion of the stalk at the point of its attachment with the pod of the walnut, and hence the fall of the latter to the ground would be the result of accident rather than design.

That it is partial to nuts, however, has been proved by more than one observer, and its ability to crack the shell of a sound hazel-nut was frequently witnessed by a correspondent of the Irish naturalist, Thompson. "These birds," says Mr. Poole, "seem to derive a considerable proportion of their autumn subsistence from the kernels of hazelnuts. They may be heard at that season in every direction, in a wood, hammering the nuts on the branches of the trees to break them."

In further illustration of the omnivorous habits of this bird may be mentioned its partiality for bees. "At Beverley," says Mr. Boyes (Zoologist, i876, p. 4873 ), " these birds have long been known to fre- 
quent the bee-hives to get the bees: it is during the winter and early spring that they do so. I am not quite certain that they take the hive-bees, though they are always accused of so doing. I fancy the dead bees, which are so often at the mouths of the hives at this season of the year, first attract them; and when they have got all they can reach I have known them to peck a large hole into an old straw hive to try to get more. Perhaps this disturbance at the entrance of a hive brings some of the halftorpid bees out to see what is the matter, and Parus major likely enough improves the occasion by devouring them. This Tit seems more insectivorous than Parus caruleus, which does not, so far as I have seen after many years' observation, indulge in this habit."

The ordinary note of the Great Tit is a loud "cheep," followed by a harsh chatter. In spring and early summer this changes to a curious see-saw note, not unlike the sound produced by sharpening a saw with a file. These notes are very loud for so small a bird, and may be heard a considerable distance.

The Great Tit occasionally imitates the notes of other birds; and a correspondent of Macgillivray 
(Mr. Hepburn) has well described its powers in this respect, and the misleading effect upon the ears of those unacquainted with this peculiarity. "I pursued one of these birds," he says, "in April, through a narrow plantation. The first note I heard was that of 'chur-r-r,' then 'chir-r-r;' it then imitated very exactly the twink of the Chaffinch, the alarm notes of the Robin and Wren, and the doleful ditty of the Yellow Bunting; next it produced a note of its own, which it repeated incessantly as it sported amongst the boughs of an old ash; then it seemed to forget this note, and emitted another, which also was soon forgotten; and, again, as if tired of its own compositions, it essayed those of its more musical brethren." "This Titmouse," he adds, "was a great nuisance to me when I began to study Ornithology, often leading me astray by his silly productions, which I thought were the notes of some bird new to me."

We doubt not that many have been similarly deceived; and this only shows the importance, indeed the necessity, of personal observation by those who would make themselves thoroughly well acquainted with the Natural History of birds. 


\section{THE BLUE TITMOUSE.}

PARUS CAERULEUS.

BIRDS which eat seeds are generally marked birds with agriculturists. If they are seen upon the ground in gardens, it is at once asserted that they are in quest of newly-sown seeds; and should they twitter about amongst the sprays in spring, they are, of course, accused of nipping off the buds and destroying the beauty of summer and the wealth of autumn. In both these situations the Tits may be observed at times, and although they come to preserve rather than to destroy, this is not generally known or admitted; they are branded as seedeating, bud-picking birds, and, as such, their fate is sealed.

Justice to the birds, and also to those who unwisely persecute them, thus demands that they should be called by the name of that food to which 


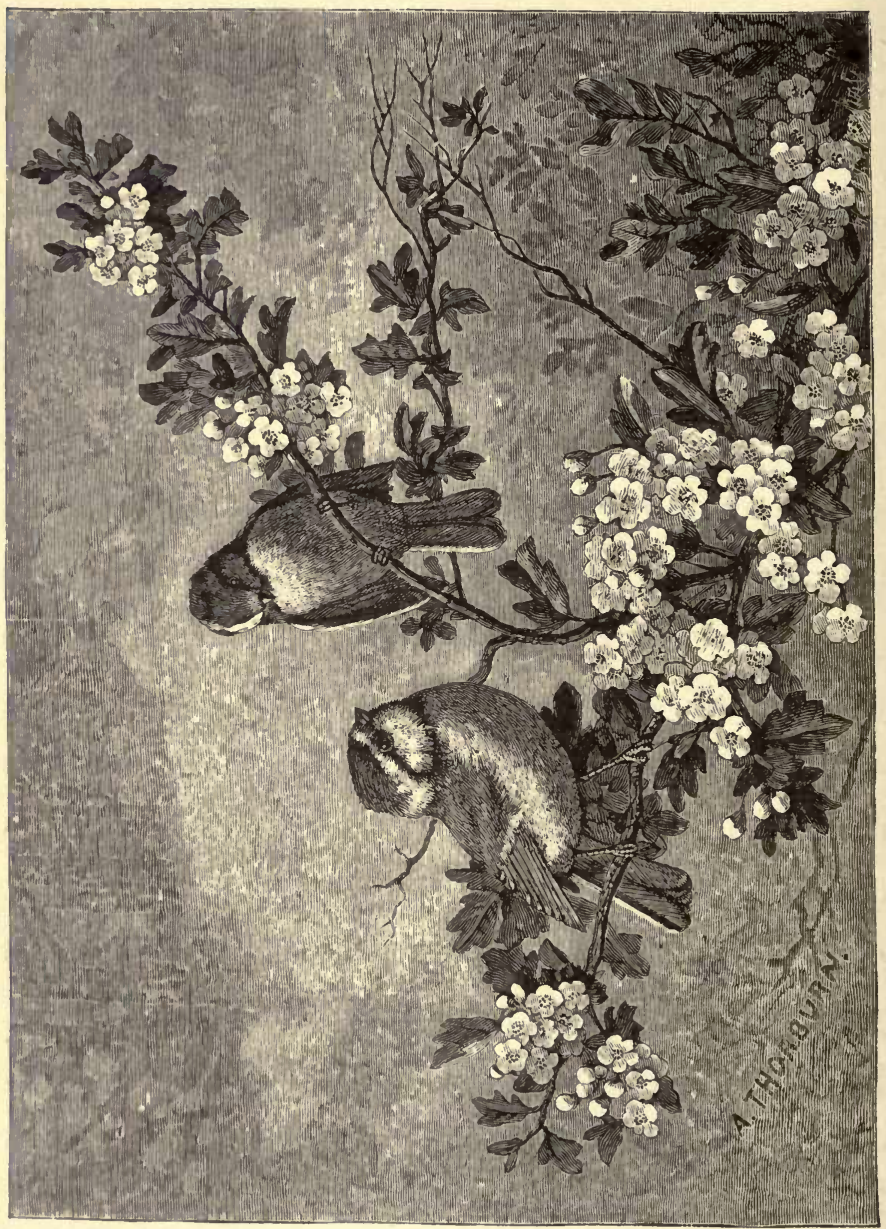

S⿺辶 
they are most partial, or in search of which they are not only more assiduous and successful, but employed more in the proper season than many of the so-called insectivorous species, and especially more than any of the Warblers. These last-named quit the country at the close of the summer, leaving the insects to deposit their eggs, and before they return, these eggs have been hatched and the mischief has been done. The Tits, on the other hand, watch the buds, more particularly the fruitbuds, from the time of their formation in the autumn until they begin to expand in the spring; and the number of eggs and larvæ of the Tortrices and other insects which they pick up, would, if left alone, be quite sufficient to ruin the crops and disfigure the trees.

"The larvæ of these lurking moths not only do mischief themselves, but are also the cause of mischief being done by others. The injury which they do to the young buds, in the very cores of which they batten, gradually brings on that languid action in the tree in consequence of which the influence of the sun, which in healthy plants would bring out a rich and luxuriant foliage, induces a saccharine 
condition of the sap which fosters the congregating caterpillars, so that they appear upon the trees in swarms, secure during the day in their silken tents, but eating voraciously at night, till not a particle of green is left; so that if the tree does not perish, it remains actionless for the year. Nor is the mischief confined to the leaves; for without their action the sap does not change into a healthy cambium fit for producing the new layers of wood and bark, which when a tree ceases to produce, its decay has begun. The whole active surface of the tree thus becomes saccharine, and is infested with swarms of insects of different kinds down to the very roots; and in the course of the summer the bole and branches become full of canker; half the top dies, branch after branch, and the miserable remnant of the once fruitful and ornamental tree becomes equally unproductive and unsightly. When a tree is thus attacked, its recovery is always doubtful and generally hopeless. Wood and bark that have stood more than one winter are much less fit for vegetable action, even though they have received no direct injury, than when they have stood only one. But in a tree which has been injured as above described the 
continuity of even the stiffened vessels is broken, and the new production, even if the tree lives, is wasted in unsightly gnarls and knobs, which afford further shelter and protection to insects, and form lodgments for water which stagnates and rots the wood. Heading down and grafting is generally only loss of time and labour; and the diseased remains inoculate other trees." ${ }^{1}$

Such would be the natural course with most trees, and with all the finer fruit trees, especially if the buds were not cleared by birds; and amongst these birds the garden-frequenting Tits are as notable in their way as are Rooks amongst the larger birds which clear the fields of insects. As a destroyer of insects of all kinds the Blue Titmouse stands pre-eminent amongst its fellows, and hunts with unwearied perseverance. It peeps into the nail-holes of our walls, which, though closed by the cobwebs, will not secrete the spider within; it draws out the chrysalis of the cabbage-butterfly from the chinks in the barn; it takes the maggots from the oak-galls, and, according to Mr. Bond, feeds its young very much with the small larvæ of the goose-

1. Mudie, Feathered Tribes of the British Islands, vol. i. p. 347. 
berry-moth, while it also preys on the grubs of wood-boring beetles, including Scolytus destructor, the worst foe of the elm.

Mr. Weir, who has contributed so many interesting notes to Macgillivray's work on British Birds, communicated the fact that he once watched the actions of a pair of Blue Tits for, an entire day during the time that they were engaged in rearing their young. He took the trouble to count the number of times they brought food to the nest, and found that they laboured incessantly for seventeen hours out of the twenty-four, during which time they fed their young 475 times, sometimes bringing a single caterpillar, at other times two or three small ones. After such testimony as this, we may well deplore, with Knapp, the short-sightedness of the churchwardens of his parish which prompted them to pass an item of payment in their accounts "for seventeen dozen of tom-tits' heads." In summer, he admits, it will certainly regale itself on our garden pease, and shells a pod of "marrowfats" with great dexterity; but this, he believes, is the extent of its criminality. "Yet," says he, "for this venial indulgence do we proscribe it, rank it 
with vermin, and set a price upon its head, giving fourpence for the dozen, probably the ancient payment when the groat was a coin." 1

The Blue Tit is very fond of picking a bone, and has even been seen to descend on the pieces of beef and mutton exposed at the door of a butcher's shop. It may readily be attracted by a bit of suet, and if this be fastened to a piece of string and allowed to hang from the end of a switch stuck slantingly into the ground, it will clear it all away by degrees, and in so doing will go through acrobatic feats as wonderful as they are amusing.

It is a fearless and friendly little bird, and in selecting a nesting-place will often come not only close to the house and occupy a hole in a tree, or wall, within sight of our windows, but will even enter an outhouse, and build its nest in such odd situations as a gardener's tool-basket, a disused watering-can, or the pocket of an old coat. Only last summer we saw a nest of this bird which had been made for the second time in an old hot-water can, which, being found to leak, had been discarded and hung up on a nail in an outhouse. The neck

1 The Fournal of a Naturalist, p. 16r. 
of this can was so small that it only just admitted the bird, and it was impossible to withdraw the nest except by pulling it to pieces. Many instances have been recorded of Blue Tits nesting in a pump, which they could only enter through the spout.

The character and materials of the nest, and the size and colour of the eggs are very similar to what we have already described in the case of two of its congeners; the chief difference in its nidification being that, like the Long-tailed Tit, it generally uses a quantity of feathers. If undisturbed one year in its nesting-place, it will return the following, and even succeeding years to the same spot; thus manifesting a confidence in the protection of man which it would be heartless to destroy. 


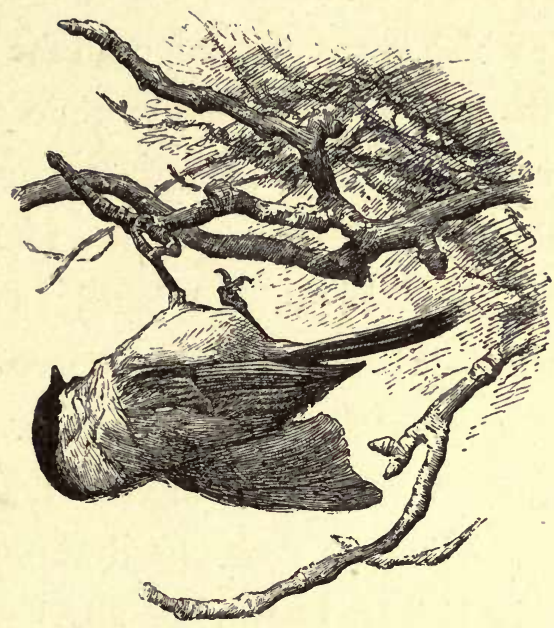

THE MARSH TITMOUSE.

PARUS PALUSTRIS.

ON the moss-grown stump of a decayed forest tree, or creeping about the half-submerged roots of some willow by the river side, we may often see the Marsh Titmouse, whose colours, though far less bright than those of its congeners, are nevertheless attractive from the quiet contrast which they present -black and gray being the prevailing hues. 
In size and general appearance it closely resembles the Coal Titmouse, but may be readily distinguished from it by the absence of the white spot on the nape which is so conspicuous in the latter bird.

In its distribution it is much more local than the other species of Parus, and is not commoner (as its name would seem to imply) in the fenlands than elsewhere. There is perhaps hardly a county in England where it has not been observed, although it is nowhere reported to be numerous. In Scotland it is much rarer, although believed to be gradually extending its range northwards; while in Ireland it is hardly known at all, having been observed on rare occasions in three counties only.

In regard to its habits and food, the Marsh Titmouse appears to be less omnivorous than the last named, deriving sustenance chiefly, though not exclusively, from insects, in its search for which it is very assiduous. In the autumn and winter months, however, when insect-life is scarce, it has been observed to live upon small seeds. It is resident with us throughout the year, and does not appear to shift its quarters much, although Messrs. Gurney and Fisher have remarked the abundance 
of the species in Norfolk, apparently occasioned by migratory arrivals, whose departure was again noticed in the following March.

Its ordinary cry, says Macgillivray, is a shrill "cheep," but it also emits a variety of chattering notes, and in spring has a kind of song, which may be expressed by the syllables chicka, chicka, chee. Towards the end of that season the little flocks disperse, separate from the individuals of the other species with which they have associated in winter, and betake themselves to the dense woods, or the marshy wooded borders of streams and pools, the chief attraction to which seems to be the decayed willows, of which the crevices afford an abundant supply of insect food.

The nest is usually placed in the hole of a tree, which the bird sometimes enlarges for this purpose. Montagu observed a Marsh Tit excavating the decayed part of a willow, carrying the chips in its bill to some distance, always working downwards, and making the bottom for the reception of the nest larger than the entrance.

The materials of which the nest is composed vary according to circumstances, but generally con- 
sist of moss, wool, and hair, some thistle-down or willow-down being occasionally added.

The eggs are characteristic of the genus Parus, being small and white, sparsely spotted with red, chiefly at the larger end. Being liable to variation, and closely resembling those of the Coal Tit and Blue Tit, they become indistinguishable in a large series, although a practised eye will doubtless discriminate them with little hesitation. The eggs of the Coal Tit are generally smaller and the markings more minute than those of the Marsh Tit. The only way to procure authentic specimens of the eggs of any of the Paridae is to find the nest, and identify the owners of it by watching their entrance and exit.

Although by far the most usual site for the nest of the Marsh Tit is a hole in some tree, this is not invariably the locality selected ; for the nest is sometimes found near the ground on a willow-stump, and instances have been noted of its being built on the stump of an oak or an elm tree. In the cases referred to the site was well concealed by moss, herbage, and underwood.

Some difference of opinion has been expressed by naturalists with regard to the excavating powers 
of the Tits, the general impression being that they merely enlarge holes where the rottenness of the wood admits of their removing particles, and that they do not actually make the holes. Upon this point, however, a good observer, the late Mr. J. D. Salmon, wrote as follows :- "I am perfectly satisfied that the Marsh Tit does occasionally excavate a situation for its nest, having in several instances found it in a decayed willow-tree, which, from the fresh appearance of the cavity, must have been done by the bird. In all the cases that have come under my observation the wood has been in that stage denominated 'touchwood.' I have never found the nest of this species on the ground, but always at an elevation of a few feet, and in a decayed tree. I cannot help suspecting that the nests of the Marsh and Coal Tits are often taken for each other."

Doubtless this is so; but we can state from personal experience that a favourite site for a nest with both these birds is a moss-grown hollow stump near the ground, in which situation we have repeatedly found it. On one occasion we discovered the nest of a Marsh Tit in a crevice in the ground, which had apparently been previously occupied by 
bees; and Mr. Gurney has known the nest of the bird to be placed in a rat's hole, burrowed down into a closely-mown lawn. It is thus evident that there is some diversity in the site selected by this species for nidification.

Though commonly met with in such situations as we have described, the Marsh Tit may also be observed at times in fir plantations, gardens, and orchards, where in autumn it feeds on various seeds. Mr. Stevenson has remarked that it is particularly partial to the seeds of the snowberry shrub, Symphoria racemosa. He writes:- "Before I had discovered the actual depredators I had often observed that the berries on these shrubs in my garden disappeared very rapidly, and, moreover, that the berries themselves were strewed about under the neighbouring trees. I was quite at a loss to account for this until one morning I observed a Marsh Titmouse flying across the grass-plot with a white ball almost as big as his head on the point of his bill. He looked so oddly at the moment, I could scarcely at first sight determine either the bird or its burthen, but as soon as he alighted on an opposite tree he gave a little wrench with his beak, and dropping the 
husk at the same time, flew off direct to the snowberry bush. The whole thing was now explained, and as I watched, another Titmouse joined the first, and these continued as long as I had time to wait, carrying off the berries on the ends of their bills to the same tree opposite, where they opened and dropped the husks, then back again for more. On picking up these husks afterwards, I found each of them split open down the side and minus the two little kidney-shaped seeds that grow in either half of the white fruit." ${ }^{1}$

No one who has attentively observed the actions of the different species of Titmouse can have failed to remark how varied are their attitudes, how rapid, yet sure, is their mode of progression. They are essentially formed for climbing, their strong feet and curved claws enabling them to take a firm hold in any position and on almost any surface. A characteristic attitude is that of hanging head downwards, as depicted in the accompanying vignette, and it may be readily conceived how small a chance of escape there is for any lurking insect when sought for by an active little bird like this, to whom no crack or crevice is inaccessible.

1 The Birds of Norfolk, vol. i. p. 147. 


\section{THE COAL TITMOUSE.}

PARUS ATER.

So many and so varied are the incidents of Bird life, that, even in such closely-allied species as those of the genus Parus, we may detect differences of habit as notewrorthy as are the variations to be observed in structure and coloration.

The external characters by which the present species may be distinguished from its near ally, the Marsh Titmouse, have been already briefly referred to. In addition to the white spot on the nape, which is not possessed by the Marsh Tit, there is in the Coal Tit a narrow white bar across the wing, which is absent in the other species.

Messrs. Sharpe and Dresser have expressed the opinion that the Coal Tit of Great Britain is distinct from the Parus ater of Continental Europe, and have proposed to name our familiar little bird Parus 
britannicus; but, having carefully read their description and examined the specimens on which their remarks were founded, we are compelled to say that we regard the differences indicated by them as too slight to warrant a specific separation. In our humble opinion it amounts to nothing more than an individual variation. And here we may be permitted to express our regret at the growing practice which (unfortunately, we think, for science) is sanctioned by many leading ornithologists of seizing upon minute and unimportant variations of colour upon which to found and name new species. In such forms as Parus britannicus, Parus persicus, Acredula irbii, Gecinus sharpii, Erythacus hyrcanus, and a host of others, we fail to see anything more than a slight variation of colour, which may be well accounted for by the differences of soil, food, and climate, to which these various forms are naturally subjected. We must not, however, be understood to imply that these slight variations of colour should be disregarded or ignored; on the contrary, their detection is rather to be commended, inasmuch as they may help, when made known, to fix approximately the origin, or country, of any particular 
specimen of a given species; but to accord to these varieties the rank of species, and to give them new names, is a practice for which, we venture to think, future inquirers will not be grateful.

As to the so-called Parus britannicus we fully endorse the opinion of Professor Newton, as expressed in the first volume of his edition of Yarrell's British Birds. At page 492 he observes:- "In the editor's eyes the difference does not amount to a specific distinction as it does in those of his industrious friends, for he finds that examples of this bird, killed during the breeding season in one of the oldest Scottish pine forests, though more resembling English than foreign specimens, are yet intermediate between them, - $\mathbf{a}$ fact which seems to show that specific differentiation has not been entirely established. $\mathrm{He}$ is therefore compelled to refuse recognition to the Parus britannicus, described by Messrs. Sharpe and Dresser (Ann. and Mag. Nat. Hist., ser. 4, viii. p. 437), and since figured in their beautiful work (parts xi. and xii.), while congratulating them on their acumen in having indicated what one school of naturalists would certainly call an 'incipient species ;' and in 
forming this resolve he has been largely helped by the kindness of those gentlemen, which has enabled him to study and compare the typical specimens with a considerable series of others, containing also three examples from the collection of $\mathrm{Mr}$. J. $\mathrm{H}$. Gurney junior, which, though obtained in Norfolk, do not differ from Continental specimens, and may be of foreign parentage; thus showing that the true Parus ater, in the eyes of those who would separate Parus britannicus from it, has occurred in England, and is possibly an occasional straggler to this country."

On the supposition that our Coal Titmouse is distinct from the true Parus ater, there is as yet no evidence of the former occurring elsewhere than in the British Islands; but if we regard it as merely a local race, then the species will be found to be very widely spread.

Like all its congeners, it is resident with us throughout the year, and is believed by some observers to be more common in England now than formerly. It has already been remarked that the Marsh Titmouse is a rare bird in Ireland. This is not so with the Coal Titmouse, which is generally distributed throughout the British Islands. It is a 
familiar little bird, visiting our gardens, and coming close to the windows to take spiders, or pick up scraps thrown to it, without any show of fear.

The nature of its food has been so accurately described by Professor Newton, in his condensed account of the observations of various naturalists, that we cannot do better than quote it :-

"Insects," he says, "form its chief food for the greater part of the year, and Macgillivray thought it lived entirely upon them; but various berries and seeds are also eaten by them, some of them, it is said, being carried off and hidden for future use. Thompson found fragments of stone in its stomach, a fact pointing to what, on other evidence, is pretty well established, namely, that this bird is more vegetarian in its diet than either of the species of Titmouse already described. Though most generally engaged among the branches of trees, it often comes to the ground in search of the pupæ and larvæ which are concealed in the grass as well as the seeds, especially those of the fir, which have dropped from above. Macgillivray was informed by $\mathrm{Mr}$. Hepburn that it delights in examining a ditch which has just been cleaned out, and that he had seen 
it pull small earthworms to pieces and devour them."

Like other members of the genus Parus, the Coal Titmouse usually builds in a hole of some decayed stump on or near the ground, sometimes on the ground itself; very rarely it has, been detected making its nest externally on the bough of a tree. One such instance has been recorded in The Zoologist for 1864 (p. 7444) by our friend Mr. Bond, who found a nest of this bird on the branch of a fir tree, close to the bole. He describes it as very like that of a Long-tailed Titmouse, but much rounder.

When built in a hole the materials and construction of the nest are very similar to those of other Tits, already described, as also are the eggs in colour, although an experienced eye may detect characteristic differences in the size and distribution of the markings. Certain it is, however, that the eggs of the Coal Tit so closely resemble those of the Marsh Tit that we should place no value on specimens of either, unless the parent bird had been seen and identified by a competent observer. 


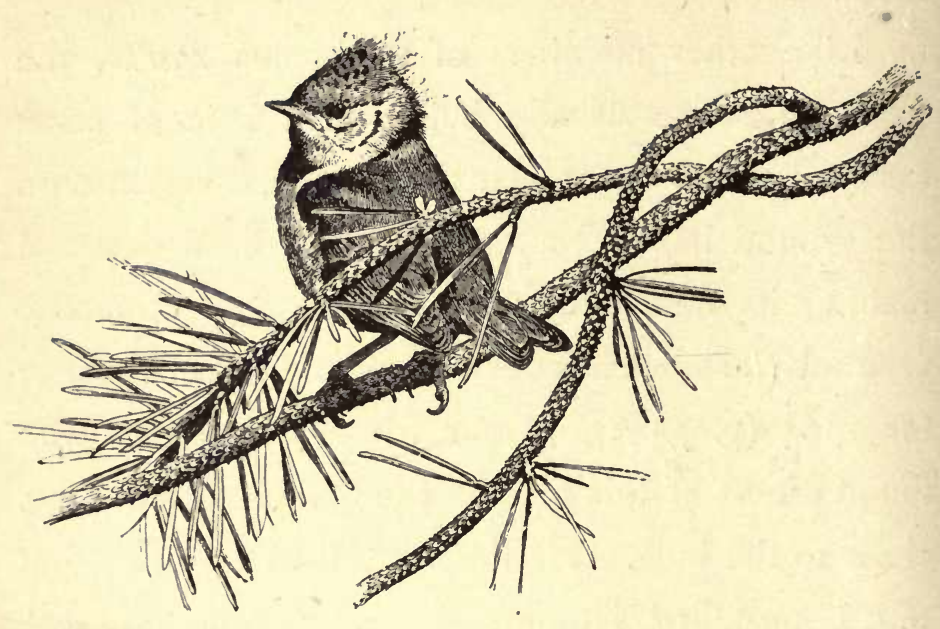

YOUNG CRESTED TITMOUSE.

\section{THE CRESTED TITMOUSE.}

\section{PARUS CRISTATUS.}

Common as this little bird is in Norway, Sweden, and Finland, and by no means scarce in parts of Scotland, where it is a permanent resident in some of the oldest forests, it must certainly be regarded as the rarest of the Tit family in England. This curious circumstance is not to be accounted for on the supposition that the bird is essentially a northern 
non-migratory species which rarely travels southward, for the observations of several good ornithologists have established the fact that it is not uncommon in the cork woods of Southern Spain, where it breeds. "The Crested Titmouse," says Colonel Irby, ${ }^{1}$ "is resident and common in the cork wood of Almoraima [near Gibraltar], in all the neighbouring pine woods, and in the valleys and on the hillsides at the back of Algeciraz up to near Tarifa, wherever the cork tree grows. It nests about the Ioth of May in the hollow stumps of boughs of the cork and pine trees, the eggs being about five in number, much spotted, and resembling strongly those of the Creeper, Certhia familiaris."

Being thus common to the North and South of Europe, it is difficult to account for its extreme rarity in our own intermediate country. Possibly the explanation may lie in the fact that, although pine woods exist in many parts of England, they are, comparatively speaking, of modern growth, and there is a notable absence of those older pine forests which overspread many parts of Scotland, and in which possibly the bird discovers some particular

1 Ornithology of the Straits of Gibraltar, p. Ior. 
insect-food which is not to be procured in the newer timber. The older and decaying wood, also, must naturally furnish more convenient nesting-places than could be easily obtained elsewhere. But whatever the cause of this scarcity may be, ornithologists are well aware that in England the Crested Titmouse is one of the rarest of our small birds.

In Ormsby's Sketches of Durham it is stated that this bird had been met with on Sunderland Moor, but from a note in Mr. Hancock's Catalogue of the Birds of Northumberland and Durham, p. 76, it would seem that this is a mistake. A second was killed at Gosforth, Cumberland (Zoologist, I 854, p. 4I67). Lewin's statement respecting its occurrence in Yorkshire (British Birds, vol. v. p. 46) has been confirmed by Mr. Martin Simpson of Whitby, who, in April I872, recorded in The Zoologist his recent acquisition of a specimen which was shot in a ravine six miles from Whitby. Mr. N. F. Hele, in his interesting Notes about Aldeburgh, Suffolk, includes this species in his list of birds as having been once obtained in the neighbourhood. Twenty years ago, two examples of the Crested Tit were procured (with an interval of two 
or three years) so near London as Kingsbury, and Blackheath, as recorded in The Birds of Middlesex, pp. 56, 57 ; while still farther to the south the bird is reported to have been met with in Stanpit Marsh, near Christchurch (Wise's New Forest, p. 3 I4), and in the Isle of Wight. ${ }^{1}$ Such are the brief records of its appearance in England.

It is clear, then, that those who would observe the habits of this little bird, within the limits of the British Islands, must seek it in the pine forests of Scotland. Moray, Ross, Inverness, Perth, Elgin, and Banff, are the counties in which it has been most frequently observed, breeding chiefly in the three first named.

"In some seasons," says Mr. Robert Gray, "this bird is much more plentiful than in others, but it is doubtful if the increase in any particular year can be attributed to a natural extension of its distribution; it probably arises from the arrival of migratory flights from other countries."

Sir William Jardine was informed by Lieut. Chauner that he had several times seen the bird

${ }^{1}$ Rev. C. N. Bury, Zoologist, 1844 and 1845 ; and A. G. More, in Venables' Guide to the Isle of Wight, p. 429.

${ }^{2}$ Birds of the West of Scotland, p. 104. 
brought fresh into Glasgow, killed in a plantation of fir not far distant. Mr. Robert Gray, however, has been unable to trace it in any part of Lanarkshire during the last twenty years.

The late Dr. H. L. Saxby, whose useful work, The Birds of Shetland, should be on every naturalist's book-shelf, has thus pleasantly described, in The Zoologist for 1872, the occasion of his first meeting with the Crested Tit among some Scotch firs at Craiglockhart, near Edinburgh.

"Their presence," he says, "was betrayed by their peculiar and incessantly repeated notes; but, even after the discovery had been made, it was no easy matter to keep the birds in view, owing to their continual restlessness, in which respect, as well as in the amusing variety of their motions, they bore a striking resemblance to the more familiar Blue Titmouse. They kept pretty near together, and, for the first twenty minutes or so after my arrival, they appeared to be making but a cursory examination of the trees, constantly flitting from branch to branch, and seemingly obtaining but little in the way of food. At length, without any apparent cause, they all flew off to a small clump of Scotch 
firs standing alone at a more sheltered part of the hillside. Whether they had received a signal from one of their number who had been sent out to explore, or whether they preferred the comparative shelter of their new position, it is impossible to say; but at any rate it was evident that they had now found an abundant supply of food, for not only did they confine themselves to one single tree, but they also appeared to be directing their attention almost exclusively to the extremities of the smaller branches, to which they might frequently be seen hanging back downwards, at the same time making vigorous use of their bills. In this manner they were still continuing to employ themselves when I left the spot about half an hour later, after having repeatedly, but in vain, endeavoured to ascertain the nature of their food, by examining such of the small branches as could be obtained. Although I broke these from the same tree, by means of a long stick, the birds were so little alarmed as merely to fly to the opposite side of the tree (which, however, was one of considerable spread), and there remain curiously eyeing me until the interruption ceased. Several hundred yards from this spot I saw two more birds 
of the same species in a thick hedge. One of them suddenly flew out of the hedge and made several snaps at a few midges which were enjoying a passing gleam of evening sunshine in a sheltered corner close by."

In a remnant of what was once a vast forest of Scotch firs, Wolley, in the spring of 1850 , found the Crested Tit pretty common; and the following year nests were sent him from the place where he had observed the birds. Mr. Hancock also found some nests the same year, placed in holes of old stumps of trees from three to six feet above the ground, and composed of rabbit's or hare's down, a little moss, and a few feathers.

The eggs, which, in Scotland, are usually laid about the end of April or beginning of May, and do not exceed five in number, are described by Professor Newton as white, blotched, spotted and speckled with light red, the markings being bigger and more collected at the larger end than in the eggs of most of its congeners. 


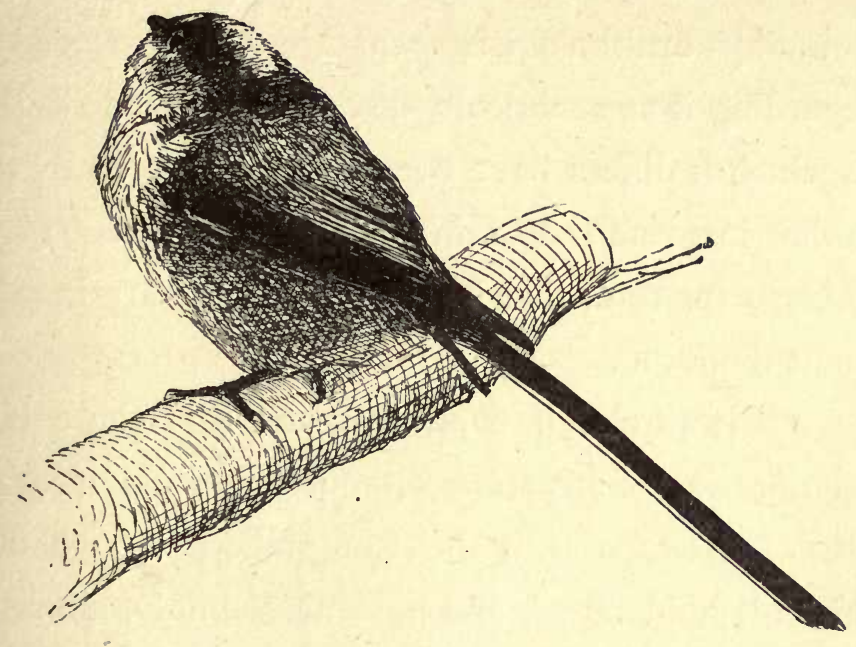

THE LONG-TAILED TITMOUSE. ACREDULA CAUDATA.

Elegant in form and attractive also in colour, the Long-tailed Titmouse arrests attention by the singularity of its appearance and of its actions. Its remarkably soft fluffy plumage, when disarranged by the wind, causes the body to resemble a tiny animated puff-ball, while its long tail seems wholly disproportionate to the length of its body.

In many respects this little bird differs structur- 
ally from its allies of the genus Parus (as long ago pointed out by the German naturalist Koch); and nowadays ornithologists seem pretty well agreed in regarding it as generically distinct. The particulars in which it differs have been so well detailed by the author just referred to, in his Säugethiere und Vögel Baierns (p. 199), that it wili be unnecessary here to point them out.

As it rarely, if ever, happens that there is a modification of structure without some modification also of habit, so with the Long-tailed Tit we find this rule holds good, and note accordingly, amongst other things, how very differently its nest is constructed as compared with the nest of a typical Parus. Instead of being a loosely-made cradle, concealed from view in some hole or crevice, it is a most carefully-made and beautiful structure, symmetrical in shape, and placed externally in the slender fork of some tree at some height from the ground, amid the denser foliage of a fir branch, or in the centre of a thick thorn.

Those who have enjoyed the pleasures of bird'snesting (and who has not-in schoolboy days, at least, if not in after-life) will recollect with what 
admiration they viewed for the first time at close quarters the wonderful nest of "the Bottle-tit." Here is an exact description of one, taken down on the spot by an excellent naturalist, no other than the observant Macgillivray:-

"Of very regular oval form, seven inches in length, and four inches and a quarter in breadth in the middle. It is composed of moss, kept together by means of the flaxen fibres of plants, some wool, and delicate filmy shreds, interwoven chiefly in a transverse direction, and has nearly the whole of its outer surface stuck over with small gray lichens, which are not agglutinated, but kept attached by filaments. The aperture, which is round, is an inch and a quarter in diameter, and an inch and a half from the summit or dome. The outer shell thus formed, although well felted and interwoven, is only a quarter of an inch thick. Its inner surface is stuck over with large feathers; and the whole internal cavity is not only lined, but filled, with the same materials. They are pretty closely compacted at the bottom and along the sides, and when shaken suffice to fill a hat of moderate dimensions." The feathers in the nest described were counted, and, 
extraordinary as it may appear, were found to number no less than 2379. They belonged chiefly to the Pheasant, Wood Pigeon, Rook, and Partridge; but there were also feathers of the breast of the Missel Thrush, of the Yellow Bunting, and several other birds.

Mr. Weir, who once had an opportunity of seeing a pair of these birds commence their nest in an old ash tree, and watched them until they had finished it, found that its construction occupied twelve days. Both male and female laboured at it in turns; and, "to give the materials the requisite solidity, they pressed them down with their breasts and the shoulders of their wings." .

Selby, in his Illustrations of British Ornithology, states (vol. i. p. 242) that "a small hole is left on two opposite sides of the nest, not only for ingress and egress, but also to prevent the bird, during incubation, from being incommoded by its long tail, which then projects through one of the orifices." If this statement was based on personal observation, the nest described must either have been an abnormal one, or a second hole may have been accidentally made in taking it from the branch to which it was 
attached. At all events, the existence of two holes is quite unusual, and opposed to the experience of many observant naturalists.

The Long-tailed Tit lays a large number of eggs for its size, as many as sixteen young birds, nearly fledged, having been found in one nest. How so large a family can live in so small a house is a marvel. It has been suggested that, in the case of so large a number of eggs being deposited, more than one hen bird may have resorted to the same nest; but this is hardly likely, for not only do the rightful owners keep a strict guard over their property, but are very bold and even pugnacious, attacking birds much larger than themselves, should they approach the nest, and driving them away.

In general appearance the eggs of this little bird resemble those of other Tits already described, but are smaller, and the small pink spots at the larger end are usually very much paler.

Like other members of the family, the Longtailed Titmouse resides with us throughout the year, and in the autumn it is no uncommon thing to see little family parties of a dozen or more hunting through the woods or along the hedgerows in com- 
pany, keeping up a shrill twit-twit, and following one after another in a long line, as if perpetually engaged in a game of "follow-my-leader."

The notes of this bird are very different from those of any of the genus Parus, being soft and weak, and audible only at a short distance. Their sound, however, as Professor Newton has remarked, suffices to assemble and keep together the flock; and in spring the cock bird has a pleasing, though feeble and short, song.

The food of the Long-tailed Titmouse is composed chiefly, if not entirely, of insects; and an examination of the stomachs of several specimens procured in winter revealed the fact that at that season they prey largely on minute Coleoptera. During the cold weather they have been observed to crowd together for warmth; and, considering the delicate appearance of these tiny birds, it is surprising how many contrive to withstand the severity of an English winter. It might naturally be supposed that by the end of winter all these small birds, which are chiefly, if not entirely, supported by insect food, would find some difficulty in providing for their wants, having consumed by their numbers and 
exertions nearly all that store of provision which had been provided in the summer and deposited in safety; but, says Knapp, in his Journal of a Naturalist, "I have found the stomach of this small Titmouse, even in February, quite filled with parts of coleopterous creatures, which by their activity and perseverance they had been enabled to procure beneath the mosses on the branches, and from the chinks in the bark of trees where they had retired in autumn."

Such plenty being procurable after the supply of so many months renders it apparent that there is no actual deficiency of food at any period of the year. The small slugs and some few insects doubtless perish from the severity of winter; but the larger portion of them are so constituted as to derive no injury from the inclemency of that season, but afford, during many months, provender to other creatures, multitudes yet remaining to continue their respective races and animate the air when the warm days of spring waken them to active life. 


\section{THE GOLDEN-CRESTED WREN.}

REGULUS CRISTATUS.

Delicate in form and as delicate in colour, the Golden-crested Wren is the most diminutive of British Birds, and one of the most generally distributed. Unlike many of the Sylviida, it is as plentiful in Scotland as in the South of England ; and, strange to say, seems almost as well able to stand the cold of winter as the heat of summer.

Although resident with us throughout the year, it receives a considerable accession to its numbers in autumn, when a regular immigration from the north and north-west takes place, hundreds crossing the North Sea in October and December.

Selby once witnessed an extraordinary arrival of Golden-crested Wrens on the Northumberland coast, which he subsequently ascertained was observed along the whole line of coast from beyond Berwick 
to Whitby. They were seen to arrive by hundreds on the beach, so fatigued and overcome by an unfavourable change of wind, by the length of their journey, or both combined, as to drop the moment they reached land, incapable of further exertion.

Mr. Cordeaux, in his Birds of the Humber District, states that on the coasts of Yorkshire and Lincolnshire the autumnal migration of the Goldcrest is as well ascertained as that of the Woodcock, and from its usually arriving just before that species, it is known as the "Woodcock-pilot," while the North Sea fishermen have told him that it often alights on their smacks, and in foggy weather perishes by hundreds. On the Norfolk coast, according to Mr. Stevenson, much the same thing has been observed.

Mr. E. T. Booth says- "I have never myself met with this species while crossing the North Sea during the autumnal migration, but several fishermen (who know the bird well) have assured me that scores have occasionally settled on their boats to rest; one man in particular stating that they would roost all night in any shelter they could find, some creeping into the blocks, where, he remarked, they 
would remain 'weeping all night,' and in the morning would fly down and pick about on the corks and other portions of the nets that were out of water. As I discovered they were known to the men by the name of 'Herring Spink,' I was particular in inquiring whether they referred to the Chaffinch, but I found they were well acquainted with that bird also. During the autumn of 1863 I found, early one morning, a fir plantation on the coast of East Lothian almost covered with these birds; there must have been scores on every tree for several acres. How such a gathering can be accounted for I am at a loss to judge, unless they had just crossed the sea from the North of Europe. I visited the same place the next day provided with a supply of dust shot, with a view to discover if any Fire-crests were among their number, but the flock had entirely disappeared."

On the east coast of Scotland Mr. Robert Gray saw a very large flock arrive one day in autumn. They took possession of a cabbage plot, and looked more like a swarm of bees than a crowd of birds. On every plant there were half a dozen or more perched, some busied in looking for insects, others 
bathing in the rain-water which had collected in the broad leaves. He walked through the plot, and, with a butterfly-net, caught ten or twelve specimens. Some of these lived in confinement for a fortnight, and were supplied regularly with insects. They became tame almost immediately, and frequently perching on his hand when held out to them, and were most interesting pets; but a single night's frost killed them all.

This sensitiveness to frost when in captivity is curious, for in a state of freedom they seem well able to withstand cold. This must, in some measure, be due to their great activity and constant motion, which doubtless enables them to a great extent to counteract the effects of seasons, and support the rigours of an English winter.

On this point the following evidence is furnished by the Hon. and Rev. W. Herbert, who says-"I once caught half a dozen Goldcrests at the beginning of winter, and they lived extremely well upon egg and meat, being exceedingly tame. At roosting time there was always a whimsical conflict amongst them for the inside places, as being the warmest, which ended, of course, by the weakest going to the 
wall. The scene began with a low whistling call amongst them to roost, and the two birds on the extreme right and left flew on the backs of those in the centre, and squeezed themselves into the middle. A fresh couple from the flanks immediately renewed the attack upon the centre, and the conflict continued until the light began to fail them. A severe frost in February killed all but one of them in one night, though in a furnished drawing-room. The survivor was preserved in a little cage by burying it every night under the sofa-cushions; but one sharp morning, having been taken from under them before the room was sufficiently warmed by the fire, though perfectly well when removed, it was dead in ten minutes."

Although in ordinary winters the Goldcrest may be able to keep itself warm by constant motion, yet in severe seasons numbers perish; and it has often happened that half a dozen or more have been picked up dead, and huddled together for the sake of warmth in outhouses, old nests, and holes of trees.

In spring there is a corresponding return journey of these birds northward. In April, according to Mr. Robert Gray, large flights suddenly appear on 
the east coast of Scotland, and actually swarm in some parts of Haddingtonshire.

It is a pleasant sight in winter to watch a flock of these tiny little birds sporting amongst the trees and enlivening the whole wood with their oftrepeated and plaintive chirp. In summer they mostly conceal themselves amongst the gloomy shade of the larch and. fir, amidst the branches of which the nest, most beautifully constructed, is artfully concealed. It is usually suspended from the under side of a branch at its extremity, being supported by two or three of the laterally diverging and pendent twigs which are interwoven with the materials of the nest. The materials employed are soft mosses felted together with spiders' webs, and lined with soft feathers. The eggs, from six to ten in number and of the size of peas, are usually of a dirty white, suffused with pale rust-colour towards the larger end, but occasionally are quite white. Selby found that they weigh from nine to ten grains each.

The song of the Goldcrest is soft and sweet, but uttered in so low a tone as to be scarcely audible at a little distance. It is heard very early in the year, generally commencing about the beginning 
or middle of February, but sometimes so soon as the end of January, especially if the weather be fine. In its habits this little bird greatly resembles the Tits, and often associates with them. Like them, it may be seen holding on to twigs head downwards while searching for its minute insect prey, and its dexterity in clinging to the trunks of trees is very remarkable. It has but little fear of man, and will often permit a very near approach. A writer in the first volume of the Magazine of Natural History affirms that it may be easily taken by striking sharply with a stone or stick the branch upon which it is sitting. The timid little bird, it is said, immediately drops to the ground, and generally dead.

To see its irregular and apparently weak flight in passing through the air on a stormy day, it would never be supposed that so tiny a creature would attempt to cross the sea, or could succeed in doing so if it tried. But that it travels to and from the Continent in spring and autumn is a fact which has been well ascertained by many competent observers, as the evidence above quoted will show. 


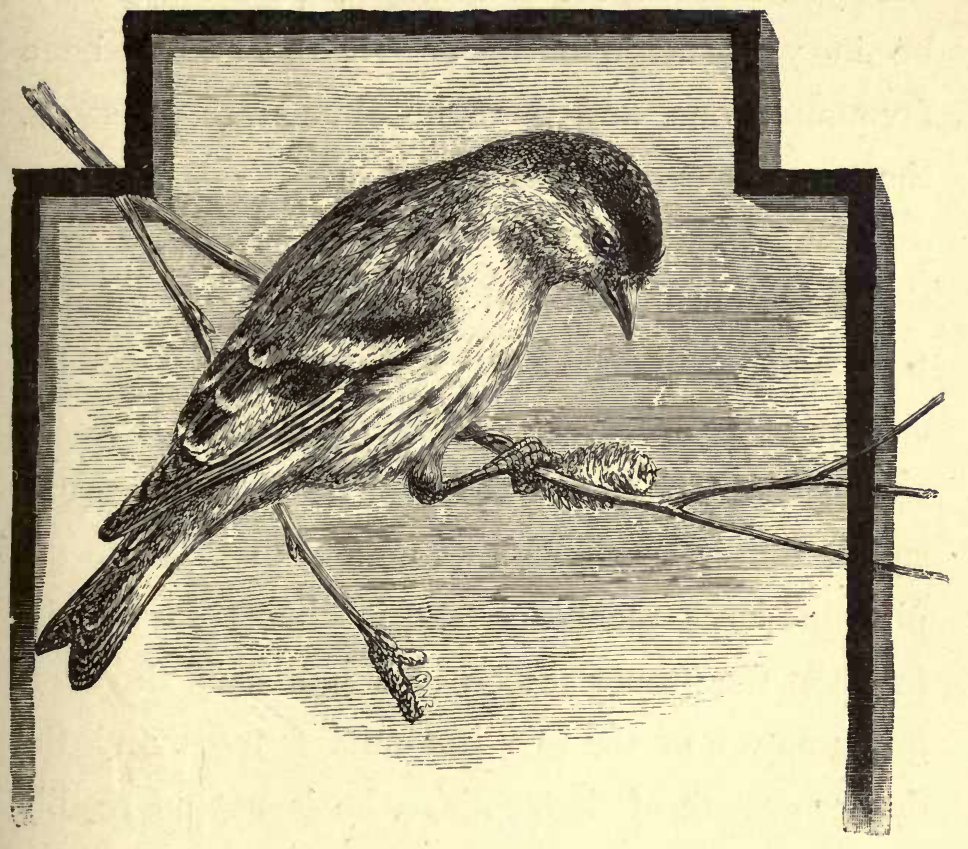

\section{T HE S I S K I N.}

FRINGILLA SPINUS.

When November comes, like the pioneeer of winter, to cut down the leaves, and scatter the seeds of the forest trees, then is the time to look for the Siskin. Follow the winding stream till the last homestead has been left far behind, and creep stealthily to the nearest alder or birch. The seeds of these two 
trees form the favourite food of the Siskin, and it is here you may expect to find him, if he happens to be in your neighbourhood. If the season be a favourable one, and there be abundance of seeds, the greater your chance of success.

The Siskin comes to us as a winter visitor from the north, but the date of his arrival is very uncertain, apparently depending as much upon a sudden change of temperature, as upon an abundance or scarcity of his favourite food. The elm and maple supply him in turn with a change of diet, and in the pine and larch plantations he is almost sure to be found at the proper season, although from the evergreen nature of the two last-named trees, and the denser growth of their foliage, he is not so readily seen there.

Our own acquaintance with the Siskin was made where the alder and elm best flourish and the larch and pine are scarce. It is therefore upon an aldertree that we introduce the bird to our readers.

In size no larger than a Linnet, but with shorter wings and tail, the male bird may be at once distinguished by his black cap and chin, his greenishyellow breast and rump, spotted flanks, and black 
and yellow wings. The tail is forked, and with a brownish-black tip. The female, more sombre in appearance, yet sufficiently like her mate to be recognised, is of a general greenish-gray above, suffused with longitudinal streaks of brownish-black, and the dark streaks, which are conspicuous on the flanks of the male, extend further in the female, to the sides and the whole of the breast. She has no black on the head or chin, but shows the greenish-yellow rump which characterises the other sex. We have remarked that in young males the black colour is confined to the head, and does not appear on the chin until they are fully mature.

The variety of attitudes which the Siskin assumes in his busy search for seeds is very striking, and reminds us a good deal of the Tit family. We have often seen the Siskin and the Marsh Tit on the same branch vying with each other in their acrobatic feats, and have been struck with the similarity of their movements; now clinging to a catkin which sways with the weight; now hanging head downwards, the more easily to extract a seed or lurking insect; anon, swinging by one foot upon 
a bending spray preparatory to a new flight, or descending jerkily to some tall reed or thistle-head only to return to the favourite tree. A prettier sight than a little flock of Siskins thus engaged can scarcely be imagined, and while the eye is pleased with their ever-varying attitudes, the ear is charmed with their incessant merry notes; for they are by no means silent at their work. A pleasing twitter, uttered, as it were, half aloud, serves as much to keep the flock together as to express the high spirits of the individuals which compose it.

A great friend of the Siskin is the Lesser Redpoll, and the two species are frequently to be seen in company, but we must confine our attention for the present to the former bird. Although as a general rule remaining with us only from November to April, there are many instances on record of the Siskin having remained to nest in England, and we are satisfied that in some parts of Scotland this bird breeds regularly every year. Mr. A. G. More, who has been at considerable pains to ascertain the distribution of birds in Great Britain during the nesting season, says of the Siskin ${ }^{1}$ - "The nest has 
been found in Lancashire (Yarrell); near Walton Hall (Waterton); in Durham (Hancock and Rev. H. B. Tristram); and in Westmoreland (Bolton quoted by Montagu). In the South of Scotland, the Siskin breeds occasionally in Dalswinton Woods, Dumfriesshire (Gibson); in Kirkcudbright (Yarrell); within two miles of Glasgow ( $R$. Gray); in Perthshire perhaps regularly; in Argyleshire; and, though not numerous as a species, may be considered to nest regularly in most of the northern counties of Scotland." In Ireland the Siskin has only been noticed as an occasional winter visitant. ${ }^{1}$

The nest and eggs resemble those of the Goldfinch upon a smaller scale, and some authors, taking into consideration the structural similarity of these two birds, have separated them from the true Fringillida and placed them in a genus by themselves under the generic name Carduelis.

Meyer has found the nest of the Siskin so near London as Coombe Wood, Wimbledon Common; and as the eggs taken were afterwards hatched under a Canary, there was no doubt about the identity of the species.

1 Thompson's Nat. Hist. of Ireland, vol. i. p. 264. 
In the third volume of his Illustrations of British Birds and their Eggs (p. 97), the above-named author gives an interesting account of two other nests of the Siskin which he found,-the one at St. Anne's Hill, Chertsey, and the other " in a wild straggling hedge in the open plain bordering the Thames, at no great distance." In both cases the parent bird was distinctly seen upon the nest.

To this account, and to some remarks by that excellent observer Charles St. John (which may be found in his Natural History and Sport in Moray, p. I IO), we refer such of our readers as seek further information than is here given.

To those who know the Siskin only as a cagebird, we say, study him in his proper haunts; steal quietly to the alder, pine, or birch tree; watch his merry antics, and listen to his sprightly song; and we venture to say that the pleasure to be thus derived will far outweigh any that can arise from the contemplation of a solitary captive. 


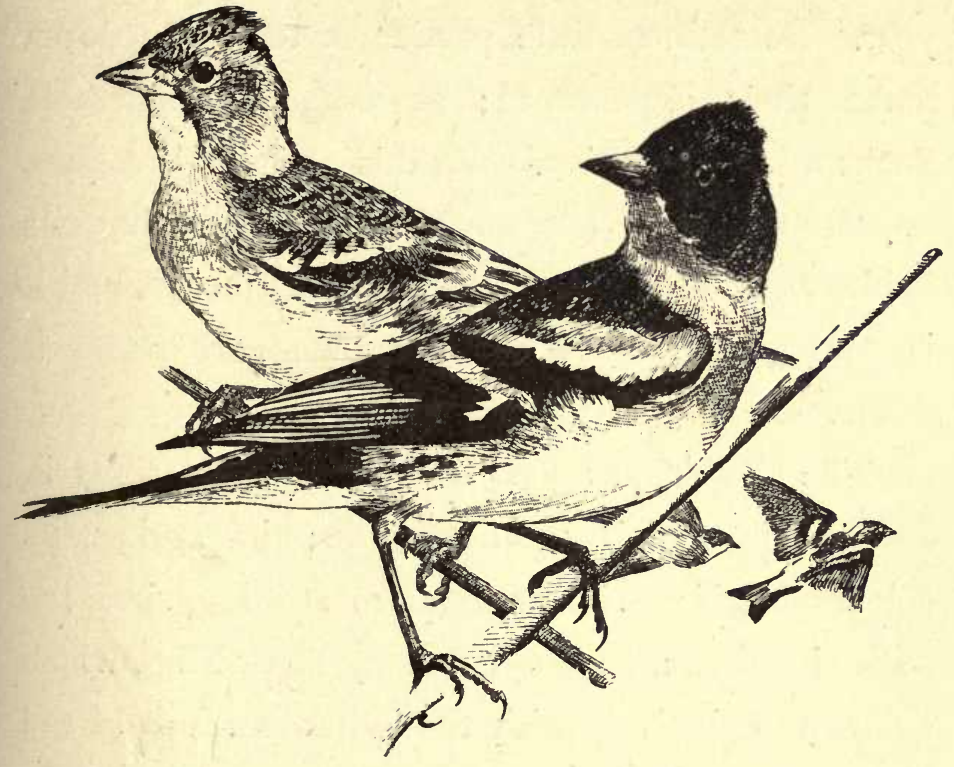

\title{
THE BRAMBLING.
}

\author{
FRINGILLA MONTIFRINGILLA.
}

Compared with other native Finches the Brambling, or Mountain Finch, cannot be regarded as a common bird. This is owing partly to the circumstance that it is not resident with us, and partly to the fact that during its migration it is very irregular as regards the date of its appearance, the localities visited, and 
the numerical strength of the passing flocks. It does not invariably visit the same localities every year. Sometimes little parties of ten or a dozen make their appearance; at others considerable flocks attract attention. On this account the same opportunities are not afforded for observing its habits as occur in the case of other Finches, and it is consequently not so well known perhaps as it deserves.

The handsome appearance which it presents in autumn is sufficiently noticeable; in spring its colours are, if possible, still more striking, since the cock bird then assumes a velvety black head, which contrasts effectively with the other portions of the plumage.

As regards the irregularity of its appearance, Professor Newton considers that it is in some degree due to the effects of climate in the mother country of the species; but it is also strongly influenced by the abundance or scarcity of food in the several parts of these islands, and with us there is hardly any season or place that produces a plentiful crop of beech-mast in which Bramblings will not make their appearance in corresponding numbers, though, 
as regards England, it must be remembered that they seem to be always comparatively rare in the midland, and still more so in the western counties.

Some idea of the numbers in which this bird is sometimes met with in winter may be gathered from what has been reported from Cornwall and Stirlingshire.

In a note from Mr. Mewburn, of St. German's, printed in Fox's Synopsis of the Newcastle Museum (p. 253), the writer, referring to a specimen of the Brambling which he had obtained and forwarded to this Museum, says:- "I selected it from among thirty or more killed at the same shot as being the finest in plumage, for they varied much. The gardeners informed me that they were then scarce to what they had been during the severe frost, when they amounted to many thousands in a flock, and quite covered the beech trees, upon the mast of which they fed, and which was that year more than usually abundant."

In January 1867 an extraordinary number of these birds was seen in Stirlingshire by Mr. Harvie Brown, as recorded in Gray's Birds of the West of Scotland. In the observer's own words, "The 
flock took the form of a column, which must have been at least a quarter of a mile in length by some fifteen yards in breadth, and presented a most singular appearance when viewed at a little distance. Every slight alteration in the direction of the flight of the birds in the van was copied by all the members of the flock behind, thus giving to the column the appearance of a great winged serpent as it twisted and undulated onward. They were flying at no great height from the ground."

"Like other strictly migratory species," says Mr. Gray, "the Brambling arrives during the night, particularly on the east coast, and is often observed, shortly after daylight, flitting among the rocks or the sea-shore, evidently in a somewhat exhausted plight after its long flight; at such times it may be almost taken with the hand. It appears at first to betake itself to the higher grounds, but after a time, especially on the approach of snow, it descends to low-lying farms, where it becomes a familiar tenant of the stackyard, mixing with Chaffinches and Yellowhammers."

In Ireland the Brambling is a frequent, if not a 
regular, winter visitant, and sometimes appears in large flocks. The Rev. George Robinson, of Tandragee, informed Thompson that one 25th March he saw a flock of some thousands, unmixed, so far as he observed, with any other species, in a beech wood at Elm Park, County Armagh, where they remained about a week.

In the neighbourhood of London we have often seen the Brambling in autumn along the banks of Kingsbury Reservoir, where they appeared to be attracted by the seeds of the bur marigold (Bidens tripartita), the knot-grass (Polygonum aviculare), and the water-pepper (Polygonum hydropiper), which last-named is very common there, and is much liked by small birds. Such numbers of these resort to the banks of this reservoir in autumn, that we have frequently seen half a dozen London birdcatchers busily employed there with their nets all day long in the month of October. The birds generally caught are Larks, Greenfinches, Chaffinches, Goldfinches, Linnets, and Redpolls, and, occasionally, Twites, Bramblings, and Tree Sparrows.

One of the most difficult birds to catch, when in small parties, is the Brambling; for this bird is so 
shy, that it will cross and recross the nets without alighting. If it flies low enough, therefore, it is generally caught on the wing by pulling the nets as it flies across. Its flight and general appearance, at a distance, is not unlike that of the Chaffinch, but it may be always distinguished from that species by the white colour of the upper tail-coverts, which at all seasons of the year is conspicuous. We were informed by the late Mr. Blyth that he had seen a living wild-caught hybrid between the Chaffinch and Brambling, in the possession of $\mathrm{Mr}$. Hugh Hanley, of the ist Life Guards.

The Brambling does not stay here late in the spring like some others of our northern visitors - the Fieldfare and Redwing, for instance. As soon as the winter is fairly over, it takes its departure, and few are seen with us after the last days of March. On one occasion, however, we procured one near Edgeware as late as I8th April. It was a male bird, and had nearly completed its nuptial plumage. It is possible that a few pairs may annually remain to breed here and there in suitable localities, but instances of its nesting in the British Islands (except in aviaries) are so rare that we can only call to mind 
a single well-authenticated case of the kind. This has been recorded by Mr. E. T. Booth in The Zoologist for 1877 (p. 60), and in the Catalogue of Birds in his Museum. He says :- "In the summer of 1866 , while fishing on the River Lyon, in Perthshire, I had occasion to climb a beech tree to release the line which had become entangled in the branches, and while so engaged a female Brambling was disturbed from her nest, containing three eggs, which was placed close to the stem of the tree. As I was anxious to procure the young, I left her, and, on again visiting the spot in about a fortnight, the nest was empty, and, judging by its appearance, I should be of opinion that the young birds had been dragged out by a cat."

So competent an observer as Mr. Booth is not likely to have mistaken a Chaffinch for a Brambling, and the fact of the hen bird having been seen on the nest affords sufficient evidence that the Brambling does at least occasionally remain to rear its young in the British Islands. 


\section{THE CHAFFINCH.}

FRINGILLA CEELEBS.

VERY striking in its actions, plumage, and song is the sprightly Chaffinch, whose vigorous if somewhat monotonous notes-poured forth, it may be, from the top of some apple-tree at no great distance from the house-seem meant as a challenge to the whole feathered choir. The Chaffinch, in point of fact, is one of the most ornamental song-birds to be found in the vicinity of man's dwelling; whether it is also one of the most useful is not so certain. Being a Finch, a hard-billed bird, with muscular gizzard, it is by nature constituted to live upon seeds and grain, and, during the winter months at least, these form its chief subsistence.

In very cold weather it may often be seen flocking, with Sparrows, Greenfinches, and Linnets, to the stackyards in search of scattered grain, and even 
turning over the horse-droppings in the roadways on the chance of picking up any undigested oats that it may discover. When the snow is on the ground, and food of all kinds becomes difficult to procure, it approaches close to the house, and is glad to pick up any crumbs and scraps that may be thrown to it. As spring approaches, and the trees come into leaf, a change takes place in the diet of the Chaffinch, and from this time until the end of summer it destroys a great number of insects, chiefly spiders, aphides, and caterpillars. In particular it feeds its young a good deal on the green caterpillars which destroy the leaves of the gooseberry. In this, amongst other respects, it may be said to be a great benefactor; for in no way are caterpillars so effectually got rid of as by encouraging certain small birds, their natural enemies. Whether the service thus rendered is sufficient compensation for the amount of grain and seed picked up at other times of the year admits of some doubt. Sir William Jardine, in his Naturalists Library, has examined the question with much fairness, and to his account (British Birds, vol. ii. p. 302) the reader may be referred, as well as to the accurate 
remarks of the author of the Journal of a Naturalist on the same subject.

"Why did Linnæus apply the specific name colebs, or bachelor, to this bird ?" is a question which will probably occur to many who may be familiar with its appearance and song, but who may not have paid much attention to its habits. The reason for this name lies in the observed fact that in Sweden the hens left the country in winter, while the cocks remained behind-bachelors for the time being. This separation of the sexes in winter has been remarked by many observers in England, amongst others by Gilbert White of Selborne; but it would appear that the rule does not admit of general application, several good ornithologists having reported their inability to detect any marked separation of the sexes, although they observed that towards the end of autumn or beginning of winter Chaffinches move in flocks, and appear more numerous at that time than during any other period of the year. There can be little doubt that at the season referred to a great number of these birds come across the North Sea, and, arriving upon the east coast of England, gradually spread over the 
country and work their way southward. On different occasions, when crossing from London to Ostend, Flushing, and Rotterdam, we have seen Chaffinches travelling on all these routes, occasionally alighting on our vessel to rest within a few yards of us, and passing on again.

Most small birds travel at night, as proved by the numbers which are picked up at the lighthouses and lightships, after dashing against the lights. From the comparatively small number of Chaffinches which thus come to an untimely end, we may infer that this bird prefers to travel by day or at early dawn. Its flight, though undulating, is tolerably rapid, and, except in hazy weather, it would experience no difficulty whatever in crossing the North Sea or the English Channel.

When fairly settled down for the summer, the actions of a pair of Chaffinches are most amusing, especially should the observer be fortunate enough to watch the operation of nest-building. Few birds make a more beautiful nest than the Chaffinch,- -so symmetrical, so compact, and so ornamental is it. The materials usually employed are wool, moss, and lichen; but the proportions in which these are 
used vary according to circumstances, and are sometimes replaced by materials which, from their colour or appearance at a distance, serve more effectually to conceal the nest from view. Thus at Whitehouse, near Belfast, as recorded by Thompson, the Chaffinches which built in the neighbourhood of two cotton-mills always made use of cotton in the construction of their nests. The mills were a quarter of a mile distant from each other, and all the nests of these birds erected in the intervening plantations, as well as in the immediate vicinity of the mills, exhibited the foreign product, not only as lining, but exteriorly. One would have supposed that its conspicuous colour would have betrayed the presence of the nests, and thus disturb the theory that birds select materials for their nests which assimilate in colour to the objects by which they are surrounded; but it appeared on inquiry that in the locality in question the use of the cotton tended rather to aid concealment, as the roadside hedges and neighbouring trees were always dotted with tufts of it. The nest is always an open, cupshaped structure, generally placed upon the branch of a tree close to the stem, sometimes with the stem 
passing partly through it, or in the centre of some hedgerow thorn, in either case being usually adorned on the outside with irregular fragments of lichen such as may be found growing on the nearest branches, rendering its detection by no means easy. As a rule, nests of the Chaffinch present but little variation in their general appearance, although now and again an odd one is met with. Thompson mentions one which was built against the stem of a pine tree, and rested on one of the branches to which it was bound with a piece of fine whipcord. This was taken once round the branch, and both the ends were firmly interwoven in the material of the nest.

The eggs, generally five in number, are of a pale greenish blue, suffused with purplish brown, and marked chiefly towards the larger end with spots and specks of dark crimson, often approaching to black. Considerable variation, however, is observable in the colour of the eggs. We have taken some which were of an almost uniform pale blue.

The young, in their nesting plumage, take after their mother in appearance, though their colours are more subdued in tone. 


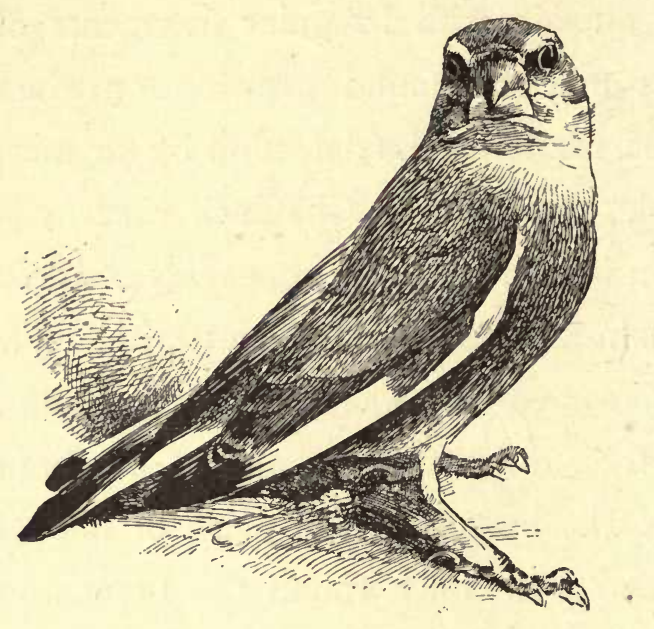

\section{THE GREENFINCH.}

COCCOTHRAUSTES CHLORIS.

Very similar in many respects to the Fringilla, or true Finches, the present bird possesses certain peculiarities of structure which ally it rather with the Hawfinch, and which have suggested the generic separation of these two species, with some others, under the name Coccothraustes. A casual glance at close quarters enables one to note immediately the unusually stout and conical bill (still more 
pronounced in the Hawfinch); the short tail, as compared with that of other Finches; and the short and robust legs and feet. A nearer inspection reveals the fact that the edges of the mandibles, instead of being plain, are inflected and slightly indented, the gape also being arched instead of straight. These little peculiarities of structure are not unaccompanied by eccentricities of habit, which it is one of the chief pastimes of the ornithologist to note.

To see the Greenfinch one has no need to go far from town. It is one of the commonest hedgerow birds we have, frequenting gardens, orchards, farm-yards, and cultivated fields, and generally in company with Sparrows and other small birds, except during the nesting season, when it keeps very much to itself, the cock bird singing from some low spray while the hen is busy with her nest. An orchard is a very favourite resort in summer, doubtless because the fruit trees furnish some specially attractive food in the shape of caterpillars and aphides, upon which it feeds its young. For, like many other hard-billed birds which live on seeds and grain during nine months of the year, the 
Greenfinch becomes insectivorous in summer, and destroys an immense number of noxious caterpillars, whose presence, if undetected by this active little bird, would easily account for the destruction of a fruit crop. We at one time fancied that the bill of the Greenfinch, so much shorter and stronger than that of many other Finches, indicated a diet composed exclusively of seeds, but since then, having on more than one occasion, in summer, seen a Greenfinch with its mouth full of small green caterpillars, we are convinced of its utility in the orchard. The young, although not treated exclusively to that insect diet with which so many small birds rear their broods, get something which not only suits them quite as well, but also indirectly benefits us, namely, small seeds which the old birds macerate and make soft for them, as Wood Pigeons do for their young; and as wheat and other cereals are not ripe when the callow brood requires food, the parent birds fall back upon seeds of various kinds, many of them common weeds, whose growth is thus happily checked.

The nest of the Greenfinch, as compared with that of the Chaffinch, is not nearly so neat and 
compact; indeed we have seen cases in which it might almost be termed a slovenly structure. It is flatter than that of the Chaffinch, and generally contains a good deal of wool and a little moss worked into a foundation of fibrous roots, the centre being lined with horse-hair. The eggs, usually five in number, have much less colour about them than those of the Chaffinch, being almost white or bluish white, with faint spots and speckles of a purplish red colour, with here and there a dash of gray, chiefly distributed at the larger end. In selecting a site for its nest, the Greenfinch is very partial to evergreens, and this fact causes it to be much commoner about gardens and shrubberies than many other Finches.

Like the Sparrow, it is fond of roosting in ivy, as proved by its being captured at night in the batfowling nets of the birdcatcher. It will thus be seen that it is a very confiding and familiar bird, not only approaching our dwellings by day, and uttering its peculiar and monotonous call incessantly during the summer months close to the house, but even resorting to the buildings (that is, such as are clothed with ivy or other creepers), under shelter of 
which it takes up its quarters for the night. This is more particularly the case in winter, when such places are resorted to for warmth; for during the summer months, when the nights are warm, the Greenfinch, like many other birds, is contented to "camp out," and sometimes roosts upon the ground with hardly any shelter beneath the canopy of heaven.

When crossing the South Downs after sunset we have often disturbed Greenfinches and Linnets from the scattered patches of heather with which the slopes of these hills are irregularly clothed, and we supposed from finding them there at so late an hour that they had settled down for the night.

In the winter, Greenfinches go about in flocks, sometimes pretty large ones. Thompson speaks of two hundred to three hundred being " not unfrequent," but we have never seen so many as this assembled at one time, and indeed have more frequently noticed them in smaller parties consorting with Sparrows and Chaffinches about the farmsteads.

They are very fond of the seed of the corn marigold (Chrysanthemum segetum), a common weed 
about corn lands; indeed some observers have remarked that they seem to prefer it to the grain amongst which it grows. At other times they feed upon the seeds of dock, plantain, dandelion, and other weeds, and in this way do good service to the farmer. On dissecting specimens to ascertain the nature of the food, we have invariably found tiny particles of grit and even brick in the stomach, swallowed no doubt intentionally, - not in mistake for seeds, but to assist in triturating the natural food which, from its hard nature, requires grinding as in a mill. This, however, is no more than we have observed in the stomachs of many other seedeating birds, as well as in some that prey largely on beetles, whose hard and horny wing-cases might be otherwise difficult of digestion, unless either broken up in this way, or rejected altogether in the shape of pills or pellets, as is the case with the Shrikes, Flycatchers, and some other birds.

In some parts of the country the Greenfinch is a favourite cage-bird, and although not endowed with any extraordinary powers of song, it has a pleasing strain of its own, and will learn to imitate the notes of other cage-birds. It soon becomes 
tame, and will perch on the hand to receive food when called.

A young bird of this species, mentioned by Yarrell, flew on to its owner's shoulder whilst walking, and became in a few days very familiar, not to say affectionate and playful.

This docility on the part of the Greenfinch is often turned to account by unscrupulous itinerant bird-dealers in London,-through whose machinations many an unwary purchaser of a so-called "beautiful foreign bird". (acquired probably at an outlay of several shillings) has returned home to find himself the possessor of nothing more nor less than a painted Greenfinch, worth twopence! 


\section{THE BULLFINCH.}

PYRRHULA VULGARIS.

THOSE who know the Bullinch only as a cage-bird would hardly recognise him in his native haunts, so different does he there appear. In a state of nature there is scarcely a more active and restless bird; in a cage "what a falling off is there!" Let us take a peep at him in some of his favourite resorts, and compare him with the sluggish songster that hops lazily from perch to perch, and pecks alternately at hemp and sugar.

We have not to go far from the house, for in the orchard hard by we are almost sure to find a Bullfinch; but we must go very quietly, for he is a shy bird, and never suffers too near an approach. Do you hear that note? There it is again; a soft double whistle, uttered very plaintively. That is the call-note of the Bullfinch, and there is the 
author of it on the top of yon cherry-tree. Now he is off. Do you see the white upper tail-coverts as he flies? You cannot mistake him on the wing. And there goes the hen; she is much plainer in her attire, but shows the same patch of white when passing from tree to tree. Now let us watch them a little. They are apparently hunting for insects, but, sad to say, they are destroying a great many blossom-buds. Cherries, apples, plums, are all in turn attacked, and it is lamentable to think that a songster of such pleasing exterior is not to be trusted in an orchard. Yet so it is, and those who wish for a good show of fruit must drive away the Bullfinch from the buds; not, as some thoughtless gardeners do, with a charge of shot, which strips off more buds in a second than a Bullfinch could pick off in an hour, but by means of scarecrows and nets and frequent visits to the trees. In this way you may save your fruit from the destroyer, and still hear his pleasing song. But it is only at a certain period of the year that the Bullfinch can do the damage of which we complain. When the young are in the nest they are fed almost entirely upon insects, chiefly caterpillars ; in autumn the old 
birds find blackberries and various seeds; while in winter the fruits of the hawthorn and dog-rose furnish their chief food.

In some parts of the country are happily still to be found those delightful green lanes which were formerly more numerous, branching off from the high road for a mile or two, and leading only to green fields. These are known as "occupation roads," being for the most part used only by the occupiers of the adjoining lands for the purpose of carting hay and other produce, and driving sheep and cattle to and from pasture. In these lanes there is no regular roadway. The turf extends the whole way between the hedges, and but for the deep ruts made by the waggon-wheels, one might almost regard them as long and very narrow fields. It often happens that in such lanes as these the hedges remain untrimmed for years, and grow to a considerable height; while in many places the lanes are so narrow that the trees on either side meet overhead. Nothing can be more beautiful than the appearance which a lane like this presents in the month of May. The hawthorn is then in full bloom, and the hedges are thickly draped with its 
white clusters. The banks are hidden with ferns and wild flowers, and a thick short turf stretches invitingly under foot. This is the spot for an ornithologist, for here the small birds love to congregate. The Chiff-chaff, Willow Wren, and noisy Whitethroat are heard and seen at intervals as we stroll down the long vista. The Swallow, first seen like a speck at the end of the lane, comes skimming over the ground impetuously towards us, only rising overhead when within a few feet, to avoid a collision; while the Chaffinch, Yellowhammer, and Great Tit, then in their best plumage, keep flitting in and out before us, and look brighter than ever against the background of white "May."

It is in a lane like this that the Bullfinch takes up his abode in summer, visiting the nearest gardens, and making raids upon the fruit-trees where opportunity occurs. As autumn goes by and winter approaches, we find him by the coverside and in more sheltered situations. Many a time when standing, gun in hand, at the corner of a wood, waiting for the approach of the beaters, have we been enlivened by watching the actions 
of the Bullfinch and his allies the Tits, and we fancy some of our friends would laugh if they knew how often we had allowed a hare to go by while noting the manœuvres of our feathered friends. It seemed to us at the time that there was a greater pleasure in observing the actions and habits of a living bird than in contemplating the body of a dead hare. But few, probably, would have agreed with us at such a moment.

We must confess that we never shot a Bullfinch, not even to ascertain by dissection the nature of its food; but, so far as we have been able to observe this bird when feeding in a state of nature, we should say that it is not insectivorous in the strict sense of the term, although, as before stated, the young are fed upon larvæ of various kinds, until they are able to take care of themselves, when they forthwith regale upon buds and fruit.

The nest is a truly wonderful structure, so loosely put together, and yet so symmetrical in shape. It is formed of twigs and fibrous roots, and looks as if a sudden gust would at once scatter all the materials; but they are so cleverly woven together, and the interior is so compactly lined 
with fine fibre, that the outside twigs, which appear so loose, are all held firmly in position.

The eggs are five or six in number, of a pale blue ground-colour, spotted and blotched towards the larger end with purplish brown. Not unfrequently these spots are so regularly dispersed over the surface as to resemble a crown of thorns. The young, when hatched, are curious little fellows, their heads and bills seeming so disproportionate in size to the rest of the body. They are wonderfully clamorous for food, and the energies of the old birds must be severely taxed in flying to and fro all day with their mouths full.

We have sometimes felt inclined to leave a Bullfinch undisturbed on a fruit-tree, in consideration of the amends he would ultimately make by destroying insects for his family. But in this case we are not prepared to say that the good would counterbalance the evil. We fear it would not. Nevertheless, we prefer to treat our little friend like a spoilt child, and would rather miss a few cherries and plums than lose the pleasure of seeing him in the garden and of listening to his cheerful song. 


\section{THE HOUSE SPARROW. PASSER DOMESTICUS.}

JUDGING from the observations of travellers who are naturalists, there would seem to be hardly any portion of the habitable, at all events of the cultivated, globe in which the House Sparrow is not well known; and this statement is all the truer since the introduction of this familiar, but much abused bird into Australia, New Zealand, and the United States.

By wonderful instinct birds will follow cultivation and make themselves denizens of new regions. The Crossbill followed the introduction of the apple into England. Glencoe, in the highlands of Scotland, never knew the Partridge till its farmers introduced corn into their lands; nor did the Sparrow appear in Siberia until the Russians had made arable the vast wastes in that part of their dominions. 
In England the Sparrow is generally regarded as one of the commonest, if not the most numerous, of all birds ; but on this point there is some difference of opinion. In an article "On the Possibility of taking an Ornithological Census," published in The Ibis for I86I, Professor Newton remarks :- "At first sight one might be almost inclined to suppose, as Mr. Wolley seems to have thought, that the House Sparrow is the most abundant of our birds. There is no question that it is one of the most characteristic, for this is shown as well by a walk through the streets of London as by a ramble in the country. But on inquiry I think it will be found that there are numerous and extensive districts in which its predominance cannot be admitted. Its habits incline it to the vicinity of human civilisation ; where it does occur, it of necessity obtains notice. In localities farther removed from the haunts of men it is clearly outnumbered by the Skylark, the Yellowhammer, and the Chaffinch; and these localities form the majority. Difficult, therefore, as it is to strike the balance, I am of opinion that its claims must be disallowed. After some reflection I have come to the conclusion 
that the Grey Partridge, in this particular district [Elveden, near Thetford], is the most abundant species we have."

The Sparrow has many foes to contend against. Hawks and Owls, birdcatchers, members of "Sparrow-clubs," farmers and owners of gardens, all carry on a war of extermination; and it is surprising, with so many enemies, how this bird contrives to live, and to live, too, in such numbers as it does.

As to its utility, or otherwise, opinions probably will never be unanimous; for agriculturists, as a rule, are firmly persuaded that it is one of the most destructive birds on a farm. There can be no question, indeed, that Sparrows eat grain and seeds of various kinds, and at a certain season of the year keep themselves liberally supplied in this respect; but what most farmers fail to realise is the fact that during the time these birds are engaged in rearing their young, the latter are fed by their parents almost exclusively on insects, being incapable at that period of their existence of digesting grain or seeds. Large numbers of noxious caterpillars, and the grubs of equally destructive beetles, as well as 
the perfect insects, are unremittingly sought out and carried to the nest; and the statistics collected by careful observers on this point reveal an astounding diligence on the part of the birds, which is the more commendable inasmuch as it operates directly and materially to man's advantage. Under one Sparrow's nest the rejected wing-cases of cockchaffers were picked up ; they numbered over I 400 ! Thus one pair of Sparrows had destroyed more than 700 insects to feed a single brood.

The great utility of these birds in preventing the devastation committed by cockchaffers was never better illustrated than by what happened some years since in the vicinity of Baden. Here a price was set on the head of the Sparrow, and soon not one was to be found in the neighbourhood. It was subsequently discovered that this bird alone could successfully contend against the cockchaffers and other winged insects; and the very men who had offered a price for its destruction offered a still higher price to introduce it again into the country.

The valuable researches of M. Florent Prévost, assistant naturalist at the Paris Museum, fully bear 
out these remarks. With the assistance and facilities given him by the administrators of Crown lands and forests, and after more than twenty years' study, he succeeded in ascertaining experimentally, week by week, the alimentary system of every landbird indigenous to France. By a careful examination of the remnants of food found in their stomachs he has been able to define for each species not only in what proportion they feed upon insects, but what particular insects they seek out and destroy, and consequently what plants they protect. A very interesting series of the dried contents of the stomachs was collected, and, as many will doubtless remember, the collection was exhibited in this country at the International Exhibition of I862, and attracted a good deal of attention. An article in No. 555 of The Field gives the details as regards twenty of the birds, including the Sparrow, and to this we would direct the attention of the reader.

The fact that when a vast number of Sparrows and other small birds have been killed, the country has been overrun with insects which destroyed the crops, proves that had the destroyers of these birds been a little more acquainted with their habits, and 
the nature of their food, the loss which they sustained might have been averted.

In the case of so well-known a bird little need be said here of its habits, which must have been so often observed by those who read these lines.

- In default of a tree or house, a chink in a rock or a hole in a wall suits him; but, after all, the nooks and eaves of buildings are his favourite resorts. Accordingly, in London, where he has his choice, he will often select droll places. Amidst the carved foliage of the capital of some Corinthian column a projection of straws, with now and then a feather, announces a nest in preparation. But some London Sparrows aspire still higher, one pair having actually built in the Lion's mouth over Northumberland House, at Charing Cross. ${ }^{1}$

The trees by St. Dunstan's Church, in the city, are a great resort of Sparrows. They come in flocks about the end of September, and stay all the winter, till about the beginning of February. At daybreak they disperse in all directions to feed, returning again to roost in the evening.

${ }^{1}$ Stanley, Familiar History of Birds, p. 225. 
Upon the Trinity Wharf, Blackwall, stands a clump of small elm trees. All the Sparrows in the neighbourhood resort there to roost, and these being the only trees within a considerable distance, their branches often support some hundreds of Sparrows. In July $\mathrm{I} 863$ these trees were struck by lightning during a storm, after the birds had retired to roost, and the following morning fiftyfour Sparrows were picked up at the foot of the trees, the majority of them quite dead, but a few just able to move. This curious circumstance was related to us by an eye-witness, an officer in the Trinity House, who picked up the birds, and who had a pair of them stuffed to commemorate the event. We were subsequently informed that a similar thing had occurred in some trees near Poplar Church, and at the Tower of London.

If the Sparrow has many enemies, he has also some friends; and, although no songster, he has been eulogised in verse by some of the older English poets, several of whom have gracefully sung the praises of "Philip Sparrow." Skelton wrote an "Elegy on the death of a pet Sparrow ;" 
and there is a pretty sonnet by Gascoyne which commences thus :-

"Of all the birds that I doo know,

Philip, my Sparrow, hath no peere;

For sit she high or lye she low,

Be she far off or be she neere,

There is no bird so faire, so fine,

Nor yet so fresh as this of mine."

The beautiful picture of "Lesbia and her Sparrow," by Sir Joshua Reynolds, the engraving of which will be familiar to many, was suggested by the poem by William Cartwright :-

"Tell me not of joy; there's none

Now my little Sparrow's gone;

$\mathrm{He}$, just as you,

Would toy and woo;

$\mathrm{He}$ would chirp and flatter me.

Then would hop and then would run, And cry 'Philip' when he'd done.

Now this faithful bird is gone;

$O$ let mournful turtles join

With loving Redbreasts, and combine,

To sing dirges o'er his stone." 


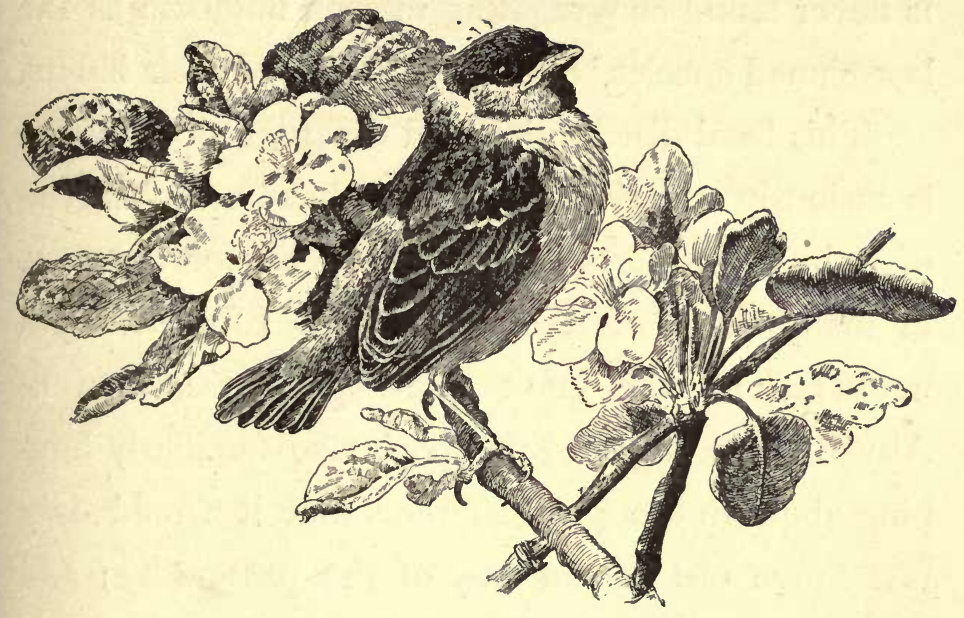

YOUNG TREE SPARROW.

THE TREE SPARROW.

PASSER MONTANUS.

Looking to the close resemblance which this bird presents to the more familiar House Sparrow, it is perhaps not surprising that it is comparatively little known, and by many people entirely overlooked. But there is another reason for its escaping notice, namely, its local distribution as compared with that of its congener.

Apart from the fact that it prefers the country to town, where it is seldom seen, it is only in certain 
districts that it is to be met with, and even then it is never found congregating in such numbers as the last-named species, ${ }^{1}$ and is altogether of shier habits.

This local distribution and different mode of life is curiously at variance with what has been observed of it in other parts of the world, as, for instance, in many parts of Asia. The late Edward Blyth wrote:- "In the great rice-exporting station of Akyáb we have seen this species so familiarly hopping about in the public streets that it would only just move out of the way of the passers-by; and we have also known it breeding so numerously in dwelling-houses as to be quite a nuisance from its incessant shrill chirping. This bird is the common House Sparrow of China and Japan, the Philippines, Burma, and more or less over the whole Malayan region; but in India it is restricted to the Northwestern Himalaya." $\mathrm{He}$ adds that throughout its vast range of distribution it exhibits no variation of

1 This does not apply at the period of the autumn migration, when a considerable accession to the numbers of the resident birds is made by the arrival of flocks from the Continent. See Rodd's Birds of Cornwall and the Scilly Isles, p. 56 ; Cordeaux's Birds of the Humber District, p. 5 I ; J. D. Power (Kent), Zoologist, I869, p. 1497; and E. T. Booth, Catalogue of Birds in his Museum, p. 215 (2d ed.) 
plumage, so that specimens from the most distant countries are undistinguishable.

Of late years it has found its way to the United States, so that its geographical range is now very extensive. Dr. J. C. Merrill, of the U.S. Army, writing in the American Naturalist for January I876, says:- "The resemblance of the species to the English House Sparrow has led me to be on the watch for it since the introduction of the latter, but without success, until I found it in St. Louis, Mo., last spring. Here I found the new species abundant, but was unwilling to take any until the breeding season was over. Four skins, sent to Mr. G. M. Lawrence, of New York, are pronounced by him to agree accurately with the plate and description of this species. He also informs me that, about five years ago, Mr. Eugene Schieffelin noticed fifty or sixty of these birds in the store of a bird importer in New York, where they were unrecognised; and these were probably afterwards sold as, or with, Passer domesticus."

This, no doubt, is the explanation of their presence in the United States, where, now that Sparrows have been so commonly imported, they 
will in all probability be found distributed in many localities.

In England, as we have said, its distribution is local, being found chiefly in the midland and eastern counties, reaching as far north as Lancashire, Cumberland, and Northumberland, with a few scattered localities on the eastern side of Scotland. According to Mr. A. G. More (Ibis, I 865), it breeds regularly in Gloucester, Hereford, Stafford, and Shropshire, where it is said to be common. Nor is it rare both in North and South Lancashire, and is believed to extend its range to Westmoreland, Cumberland, and Northumberland. It is unknown in Orkney and Shetland; but, strange to say, about ten years ago, a few pairs having found their way to the island of Skuoe, one of the Faröes, probably from the rigging of some passing vessel, they have increased and multiplied there.

When Thompson published his Natural History of Ireland, a quarter of a century ago, he included the Tree Sparrow as "a doubtful native," relying upon a statement in Templeton's Catalogue, and never having met with it himself. In I870, however, Mr. Blake Knox detected it at Dalkey and 
Baldoyle, in the County Dublin, where he found it was known to the birdcatchers, who accurately described it. They characterised it as scarce, but believed it to be resident (Zoologist, 1870, p. 2018).

It would seem, from the observations of those who have enjoyed the best opportunities for studying the habits of this bird, that the Tree Sparrow, as a rule, is partial to pollard willows, in the holes of which it frequently makes its nest. Mr. G. W. P. Moor, for instance, reports that this bird builds in large numbers along the sides of the Cam, where he has seen many eggs taken from the holes in the old pollard willow trees (Zoologist, I874, p. 4076). The late Henry Doubleday, of Epping, also testified to the fact of several pairs having their nests in the holes of some old pollard willows near Aldwinkle, in Northamptonshire (Zoologist, 1874, p. 3998). The nest consists usually of a little dry grass with a lining of feathers, and the eggs are not unlike those of the House Sparrow in colour, although smaller and somewhat rounder. But although the Tree Sparrow generally selects a tree for its nest-hence the distinguishing name of the bird-it is not to be supposed that it never resorts 
to barns and outbuildings like the common House Sparrow. We have the evidence of several observers to the contrary. Yarrell was informed by a correspondent in Rutlandshire that he had seen it building in the thatch of a barn in company with Common Sparrows ; and the author of the standard work on British Birds' eggs states that in Northumberland he has known it to breed under the coping of old walls, also in company with House Sparrows. Mr. E. T. Booth's evidence on this point is very strong. He says:- "I took particular trouble to hunt for the breeding quarters of these birds round several farms in the east of Norfolk (where they are common), and in every instance the nest was placed amongst the buildings; some in cowsheds, others under the tiles of the outhouses, and three or four among the rough stems of some particularly coarse ivy that grew over an old wall. Not one did I discover amongst the trees, though the House Sparrows were breeding plentifully both in the branches and the ivy round the trunks."

The food of the Tree Sparrow probably does not differ much from that of the commoner species. It feeds largely on seeds, and does no small service 
in picking up those of noxious weeds. Mr. Cordeaux, who examined several shot in January, found their crops and gizzards full of the seeds of the great plantain (Plantago major).

Although, to a casual observer, there may appear to be a close resemblance between the Tree Sparrow and the House Sparrow, the former may always be distinguished from the latter by its chestnut-coloured head, more slender bill, and a triangular patch of black on each cheek.

There is another respect in which this bird differs from its congener. The plumage in both sexes is alike, and the young also exhibit the same markings in their first feathers, as shown in the accompanying vignette. 


\section{THE JAY.}

GARRULUS GLANDARIUS.

When strolling through the woods in November, with the remembrance of what they were in May, we cannot fail to be struck at the change which has taken place. The warm tints of autumn have disappeared; the leaves are gone; the forest trunks are moist and moss-grown; slimy fungi overspread their roots, and various species of Helix and Clausilia are found upon the bark. On every twig a drop of moisture glistens, and as it falls upon the brown leaves below, all nature seems to weep that summer is gone. And this change is not only apparent in the trees, but in the very birds which cross our path. We now see quite a different class to that which thronged the woods in spring. The Willow Wren, Wood Wren, Chiff-chaff, Blackcap, Nightingale, and noisy Whitethroat, which flitted so 
conspicuously before us then, have all since disappeared; and while Tits of various species seem more numerous than ever, we notice new arrivals, and listen to the whistle and chatter of the Redwing and Fieldfare, which have come to pass the winter with us.

But since the leaves have fallen, a curtain has dropped which long concealed from view our shier woodbirds. The Pigeon, of whose presence we were usually aware from hearing his loud "coo," or flapping wing, is now seen perched upon the leafless bough. We can now watch every movement of the nimble Nuthatch, and observe the stealthy actions of the Creeper, and as we pick the last over-ripe blackberry, or taste the fallen beech-mast, in our search for shells or fungi, we fancy that November is not such a dull month after all as some would represent it. On the contrary, a prying naturalist can find much to interest him at this season of the year.

A noisy chattering disturbs our reflections, and we look up just in time to catch sight of one of the shiest of our wood-birds, the Jay. So long as the green leaves screened our approach, we knew him only "as the blind man knows the Cuckoo-by the 
bad voice;" but now that this screen is gone, we can see the author of the noise in all the glory of his bright plumage.

Who has not stopped at the end of a green

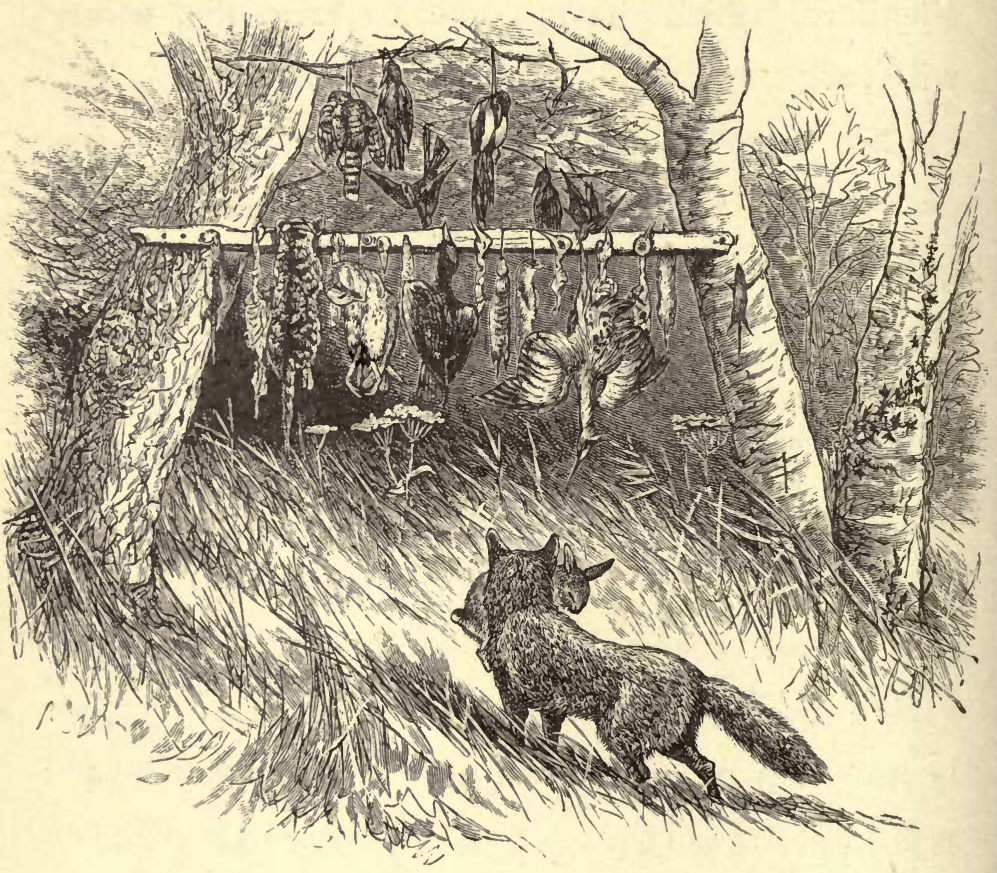

"ride" to admire the dead Jay, strung up, like a thief, amidst Hawks, Cats, and Stoats? His rosybrown back, white tail-coverts, and black-and-white wings, with their bright blue coverts, render him one of the handsomest of our woodland birds.

1 Merchant of Venice, act v., sc. I. 
Under the name of Corvus glandarius, the Jay has been ranked amongst the Crows; but although to a certain extent there is a family resemblance, those who have had the opportunity of observing the present species in a wild state will agree that in haunts, habits, and the nature of his food, he differs remarkably from all his sable friends, and that the generic name Garrulus, which Brisson, in 1760 , proposed for the Jays, was not only deservedly but appropriately applied. Our British Jay has been called glandarius from his partiality for acorns. beech-mast, and other forest fruits; but he is in fact omnivorous ; for in addition to the food already named, he takes grubs, worms, mice, eggs, and young birds, and becomes remarkably bold in the autumn in robbing orchards of cherries and damsons. He has a curious habit of hoarding up food for future occasion, and has frequently been detected on a visit to a large store of acorns. The Jay evinces a great partiality for oak-woods: we have always noticed the species more frequently where oaks abound-no doubt on account of the sustenance and shelter which these trees afford.

The nest is generally placed in the fork of a tree, 
and usually at no great height from the ground. The egg is a very plain one for the bird which lays it; the ground colour white, so closely freckled over with gray or yellowish-brown as to give it the appearance at a little distance of being uniformly gray or brown. Not unfrequently there are three or four hair-lines of a blackish colour at the larger end.

When the young are able to fly, instead of leaving the place of their birth and shifting for themselves, as the young of many birds do, they remain a long time with their parents, going about the woods in little family parties with much chattering and screaming.

The Jay is wonderfully inquisitive, and, although shy enough if he catches sight of you, he may nevertheless be decoyed within thirty or forty yards, if you remain concealed. We have seen a French gamekeeper bring a Jay within shot by imitating the squeal of a young rabbit; but we could never get very near to one of these birds by trying to "stalk" him. The sense of hearing in the Jay is so acute that, even when he cannot see you, the cracking of a twig under foot is often sufficient to alarm 
him, and away he goes with a chatter, as it seems, of derision. Keepers generally find the trap more effective than the gun if they want to destroy a Jay.

If taken young and well trained, this bird makes a most amusing pet, not only from his curious actions, but from his great powers of mimicry. $\mathrm{He}$ will learn to whistle, and imitate a cat, dog, or hen to great perfection. In some parts of Sussex we have often noticed tame Jays at the cottage-doors, and we have wondered why a bird of such attractive plumage and such engaging manners is not more generally sought after.

If, instead of being killed by shot or trap, Jays were taken alive, the object of the game-preserver would be accomplished, the keeper would be rewarded, the bird-fancier delighted, and the life of a beautiful bird would be spared. 


\section{THE CUCKOO.}

CUCULUS CANORUS.

Long before a decided taste for ornithology had possessed our youthful mind, when we ran hither and thither in the early spring, to pluck the first cowslip and the "nodding violet," did we start and pause on hearing the Cuckoo's note; and as we watched the plain gray bird flit from the ash-tree, and skim hawk-like across the meadow, we longed to have him in our hands, and, childlike, see how he made the noise. Where he came from, or why we only saw him between April and August we could not tell. There was always a mystery about the bird which we could not fathom; and we never listened to his note, or crept stealthily along the hedgerow to try and see him, without a feeling of wonderment and awe. This feeling has of course long since passed away; but even now we never 


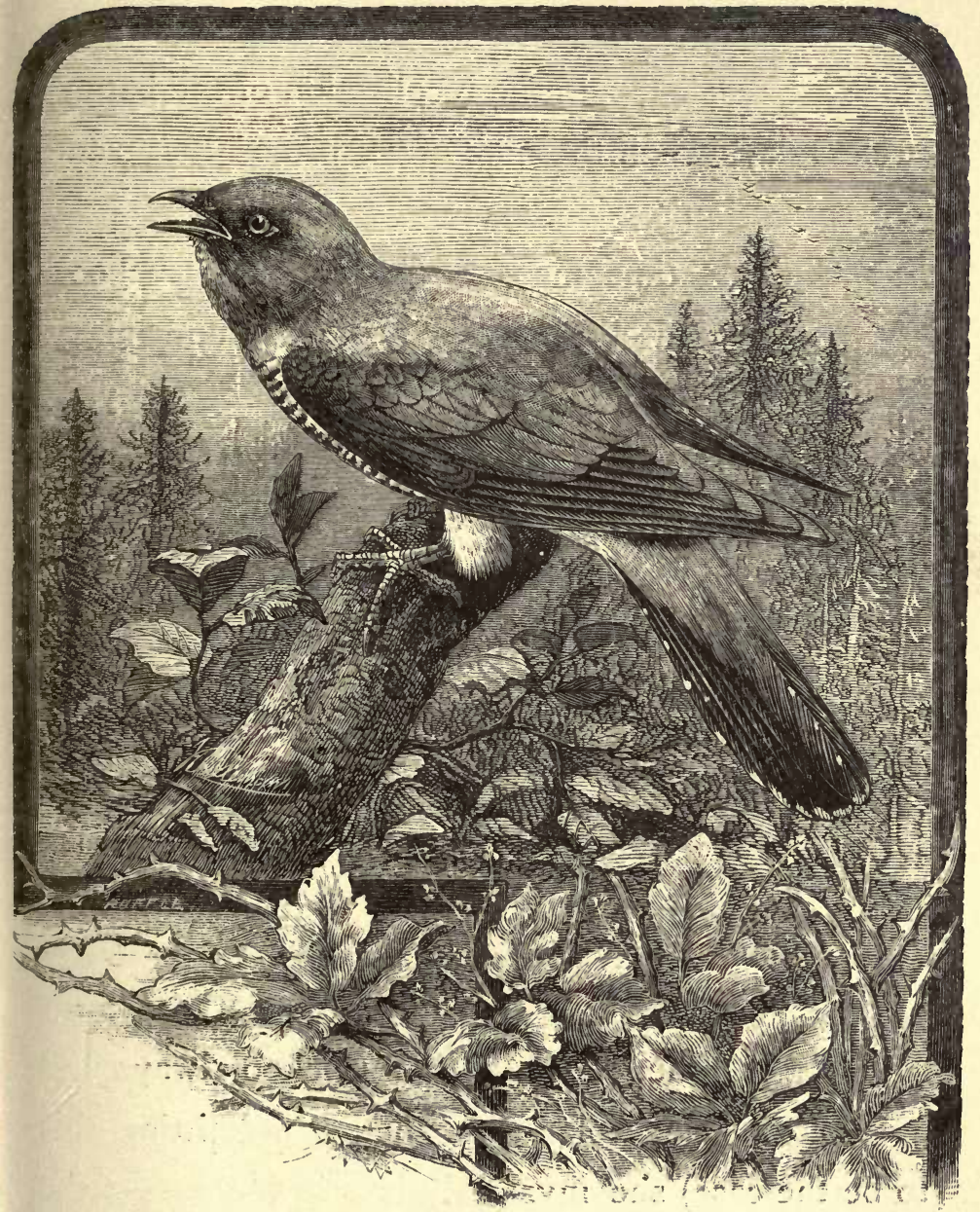

THE CUCKOO. 
hear our old friend without an indescribable sense of pleasure, which is heightened by the old associations which are recalled, and the recollection of the happy, careless days when the note of "Cuckoo" first made so great an impression.

Since that time many a Cuckoo and Cuckoo's egg has passed through our hands, and many excellent opportunities have we enjoyed of studying the habits of this curious bird.

Considering the amount of attention which has been bestowed upon the Cuckoo by naturalists in every age down to the present, one might readily suppose that every fact in connection with its lifehistory was now pretty generally known. But such is not the case. There are still certain points which require investigation, and which, owing chiefly to the vagrant habits of the bird, are not easily determined.

How can it be ascertained with certainty, for example, whether the same hen Cuckoo always lays eggs of the same colour, or whether (admitting this to be the case) she invariably lays in the nest of the same species-that is, in the nest of that species whose eggs most nearly approximate in colour to her own? 
And yet we must be satisfied on these points if we are to accept the ingenious theory of Dr. Baldamus. If we understand the learned German rightly, he states that, with a view to insure the preservation of species which would otherwise be exposed to danger, Nature has endowed every hen Cuckoo with the faculty of laying eggs similar in colour to those of the species in whose nest she lays, in order that they may be less easily detected by the foster parents, and that she only makes use of the nest of some other species (i.e. of one whose eggs do not resemble her own) when, at the time she is ready to lay, a nest of the former description is not at hand. This statement, which concludes a long and interesting article on the subject in the German ornithological journal Naumannia, for I 853 , has deservedly attracted much attention. English readers were presented with an epitome of this article by Mr. Dawson Rowley in the Ibis for 1865 , and the Rev. A. C. Smith, after bringing it to the notice of the Wiltshire Archæological Society in the same year, published a literal translation of the paper in the Zoologist for I868. In Nature, i8th November I869, appeared an interesting article on 
the subject from Professor Newton, who subsequently published a more exhaustive biography of the bird in the Encyclopadia Britannica, ninth edition.

To enter fully upon the details of this interesting subject, would require more space than we have at our disposal; we can only glance, therefore, at the general opinions which have been expressed in connection with it.

If the theory of Dr. Baldamus be correct, is it possible to give a reasonable and satisfactory explanation of it? This question has been answered by Professor Newton in the article in Nature to which we have just referred. He says :- "Without attributing any wonderful sagacity to the Cuckoo, it does seem likely that the bird which once successfully deposited her eggs in a Reed Wren's or a Titlark's nest, should again seek for another Reed Wren's or a Titlark's nest (as the case may be) when she had an egg to dispose of, and that she should continue her practice from one season to another. We know that year after year the same migratory bird will return to the same locality, and build its nest in almost the same spot. Though the 
Cuckoo be somewhat of a vagrant, there is no improbability of her being subject to thus much regularity of habit, and indeed such has been asserted as an observed fact. If, then, this be so, there is every probability of her offspring inheriting the same habit, and the daughter of a Cuckoo which always placed her egg in a Reed Wren's or a Titlark's nest doing the like." In other words, the habit of depositing an egg in the nest of a particular species of bird is likely to become hereditary.

This would be an excellent argument in support of the theory, were it not for one expression, upon which the whole value of the argument seems to us to depend. What is meant by the expression "once successfully deposited"? Does the Cuckoo ever revisit a nest in which she has placed an egg, and satisfy herself that her offspring is hatched and cared for? If not (and we believe such an event is not usual, if indeed it has ever been known to occur), then nothing has been gained by the selection of a Reed Wren's or Titlark's nest (as the case may be), and the Cuckoo can have no reason for continuing the practice of using the same kind of nest from one season to another. 
While admitting, therefore, the tendency which certain habits have to become hereditary in certain animals, we feel compelled to reject the application of this principle in the case of the Cuckoo, on the ground that it can only hold good where the habit results in an advantage to the species, and in the present instance we have no proof either that there is an advantage, or, if there is, that the Cuckoo is sensible of it.

Touching the question of similarity between eggs laid by the same bird, Professor Newton says : - "I am in a position to maintain positively that there is a family likeness between the eggs laid by the same bird" (not a Cuckoo) "even at an interval of many years," and he instances cases of certain Golden Eagles which came under his own observation. But do we not as frequently meet with instances in which eggs laid by the same bird are totally different in appearance? Take the case of a bird which lays four or five eggs in its own nest before it commences to sit upon them-for example, the Sparrow-hawk, Blackbird, Missel-Thrush, Carrion Crow, Stone Curlew, or Black-headed Gull. Who has not found nests of any or all of these in 
which one egg, and sometimes more, differed entirely from the rest? And yet in each instance these were laid, as we may presume, not only by the same hen, but by the same hen under the same conditions, which can be seldom, if ever, the case with a Cuckoo.

Looking to the many instances in which eggs laid by the same bird, in the same nest, and under the same circumstances, vary inter se, it is not reasonable to suppose that eggs of the same Cuckoo deposited in different nests, under different circumstances, and, presumably, different conditions of the ovary, would resemble each other. On the contrary, there is reason to expect they would be dissimilar. Further, we can confirm the statement of $\mathrm{Mr}$. Dawson Rowley, who says, "I have found two types of Cuckoo's eggs, laid, as I am nearly sure, by the same bird" (Ibis, 1865, p. I83).

It is undeniable that strong impressions upon the sense of sight, affecting the parent during conception or an early stage of pregnancy, may and do influence the formation of the embryo, and it has consequently been asserted that the sight of the eggs lying in the nest has such an influence on the hen Cuckoo, that her egg, which is ready to be laid, 
assumes the colour and markings of those before her. This is not, however, supported by facts. For the egg of a Cuckoo is frequently found with eggs which do not in the least resemble it (e.g. those of the Hedge Sparrow); or with eggs which from the nature of the nest could not have been seen by the Cuckoo (as in the case of the Redstart, Wren, or Willow Wren); or deposited in a nest before a single egg had been laid therein by the rightful owner. Again, two Cuckoo's eggs of a different colour have been found in the same nest. If both were laid by one bird, we have a proof that the same Cuckoo does not always lay eggs of the same colour; if laid by different birds, then the Cuckoo is not so impressionable as has been supposed.

What really takes place, we believe, is this:The Cuckoo lays her egg upon the ground; the colour of the egg is variable according to the condition of the ovary, which depends upon the age of the bird, the nature of its food, and state of health at the time of oviposition. With her egg in her bill, the bird then seeks a nest wherein to place it. We are not unwilling to accept the suggestion that, being 
cognisant of colour, she prefers a nest which contains eggs similar to her own, in order that the latter may be less easily discovered by the foster parents. At the same time, we so frequently find the egg in question amongst others which differ totally from it in colour, that we cannot think that the Cuckoo is so particular in her choice as Dr. Baldamus and the supporters of his theory would have us believe. A friend of Gilbert White found upon trial that the note of the Cuckoo varies in different individuals. About Selborne Wood he found they were mostly in $\mathrm{D}$. He heard two sing together, the one in D, the other in D sharp, which made a very disagreeable duet. He afterwards heard one in D sharp, and about Wolmer Forest some in C. Gungl, in his "Cuckoo Galop," gives the note of the Cuckoo as B natural and G sharp. Dr. Arne, in his music to the Cuckoo's song in Love's Labour's Lost, gives it as $\mathrm{C}$ natural and $\mathrm{G}$. 


\section{THE HOOPOE.}

UPUPA EPOPS.

Not a summer elapses without the appearance in different parts of the British Islands of that singular but attractive bird, the Hoopoe. It is, in fact, an annual summer visitant to this country; and from what has been observed of its habits, there can be no doubt that it would breed here regularly if allowed to remain unmolested. Unfortunately, however, it is too often pursued and wantonly shot as soon as detected, and we are thus deprived of the pleasure of seeing a bird which is as useful as it is ornamental, and of listening to a note which is one of the most singular of any to be heard in the feathered choir. If the thoughtless persons whose first impulse on seeing an uncommon bird is to procure a gun and shoot it would only take as much pains to afford it protection for a time, observe its 
habits, describe its mode of nesting, and manner of feeding its young, they would do a much greater service to Ornithology by recording the result of their observations than by publishing the details of a wanton destruction.

That the Hoopoe will breed in this country, if unmolested, is evidenced by the recorded instances in which it has done so where sufficient protection has been afforded it during the nesting season. Montagu states, in his Ornithological Dictionary, that a pair of Hoopoes began a nest in Hampshire, and Latham has described a young Hoopoe which was brought to him in June. A pair one summer frequented Gilbert White's garden at Selborne; and another pair nested for several years in the grounds of Pennsylvania Castle, Portland (The Naturalist, I852, p. 82). Jesse, in his Gleanings in Natural History, states that some years ago a pair of Hoopoes built their nest and hatched their young in a tree close to the house at Park End, near Chichester; and according to the observations of Mr. Turner of Sherborne, Dorsetshire, the nest has been taken, on three or four occasions, by the schoolboys, from pollard willows on the banks of 
the River Lenthay, where the birds were known to the boys as "Hoops." In the same county, on the authority of the Rev. O. P. Cambridge, the Hoopoe is said to have bred at Warmwell. The Rev. A. C. Smith states that a nest containing young birds was taken many years ago near Calne, Wilts; and another nest, according to Mr. A. E. Knox, was found at Southwick, near Shoreham. Canon Tristram states that the Hoopoe has bred at least on one occasion in Northamptonshire. Mr. Howard Saunders informs us that many years ago a pair of Hoopoes took possession of a hole in a yew tree in the shrubbery of a garden at Leatherhead, and reared their young in safety. He afterwards saw both old and young birds strutting about on the lawn.

The Hoopoe does not carry the crest erect, but nclining backwards, and it is only elevated from time to time. On the wing, at first sight, it reminds one of a Jay, the principal colours being the samenamely, black, white, and cinnamon-brown; but the distribution of colours is different, and the flight is not so rapid, and more undulating. The wings are large for the size of the bird, and the first quillfeather being shorter than the second gives the 
wing a rounded appearance, which makes the flight seem heavier.

The Hoopoe lives a good deal on the ground,

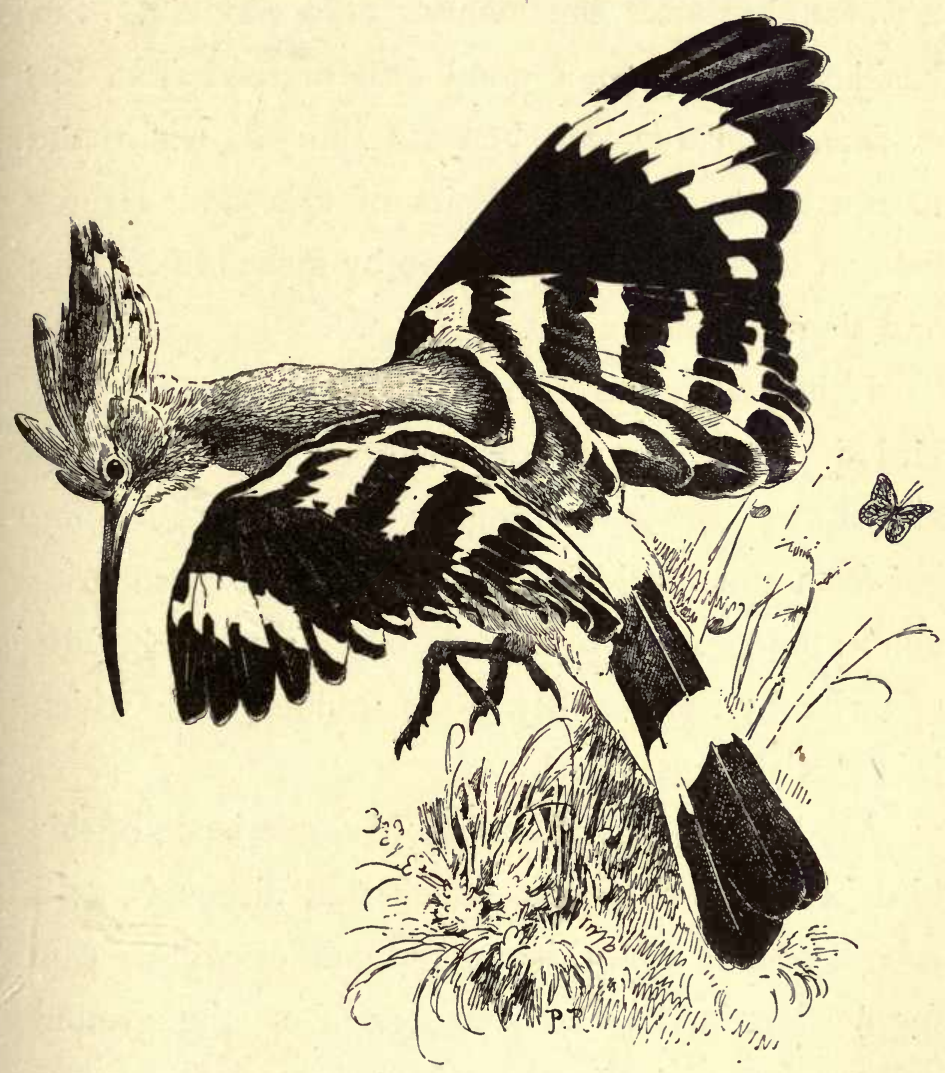

where it finds its chief food, which consists of beetles of various kinds and their larvæ, caterpillars, and ants. It is especially partial to dung-beetles, 
and in France we have often watched it searching for them amongst horse-droppings on the high roads, where we have also seen it dusting itself on a warm day, after the manner of a Skylark. But besides picking up a good deal of food from the surface, it also probes beneath the soil, where the nature of the ground admits of this, and secures many a worm and lurking grub by means of its long and slender-pointed bill.

It builds in the hole of a tree, where the hen bird sits on the eggs without interruption until they are hatched, the male bringing her food and feeding her from the outside of the hole. One peculiarity about the nest is that it is often rendered quite offensive by the quantity of horse-dung with which it is partially composed.

Lord Lilford, in narrating his experience of this bird in Southern Spain, states that although, as a rule, it prefers a hole in an old ash or willow tree for nesting in, he has seen a nest on the ground under a large stone, others in holes on the sunny side of mud or brick walls, one in a fissure of limestone rock, and another in a small cavern.

The eggs, which are generally five or six in 
number, are elongated, oval, and of a greenish-gray colour. The young when first hatched are naked, but soon get covered with small blue quills, from which the feathers sprout. They are unable to stand upright until nearly fledged, but crouch forward, uttering a hissing noise. Their crests are soon developed, but their bills do not acquire their full length until the following year.

The note of the Hoopoe is very remarkable, and not to be mistaken for that of any other bird. It sounds like the syllables "hoop-hoop," "hoop-hoop," frequently repeated, and in the quality of its tone approximates to the call of the Cuckoo, but the second note is a repetition of the first, instead of being, as in the case of the Cuckoo, a third below it.

The average date of arrival of the Hoopoe in England may be said to be the third week in April, when the bird is more frequently met with in the eastern and south-eastern counties, although it wanders inland to a considerable distance. It is regarded by Mr. R. Gray as a straggler to Scotland; and Thompson remarks that in Ireland it has appeared occasionally in all quarters of the island.

As autumn approaches, these birds, or such of 
them as have contrived to escape destruction, begin to move southwards for the winter, and, passing gradually down to the Mediterranean, are observed for some days about the groves and olive-gardens near the sea before they finally cross over. In this way they return to their winter haunts about the end of August or beginning of September. Occasionally a Hoopoe has been observed in winter in the British Islands, but so rarely as to make the occurrence worthy of note in some one or other of the Natural History journals. Charlton, in his Onomasticon Zoicon (1668), gives a life-size engraving (p. 92) of a Hoopoe killed near London in the winter of 1666 ; and Dr. Smith, in his History of Waterford (I774), records another which was shot upon the ruins of the old church of Stradbally, during the great frost of I739. According to the Rev. A. Matthews (Zoologist, I839, p. 2598), a Hoopoe was killed near Oxford in February 1838 , and the late Sir William Jardine informed us that two were shot in Dumfriesshire in the winter of I 870-7 I. 


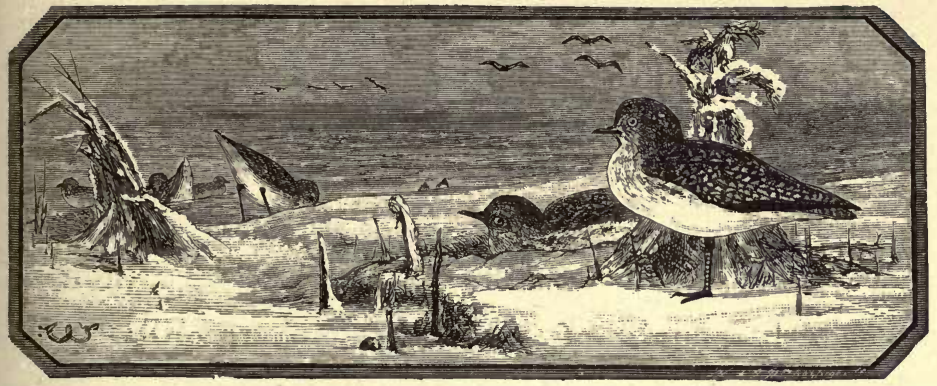

THE GOLDEN PLOVER.

CHARADRIUS PLUVIALIS.

Although this beautiful Plover may be considered to be with us an indigenous species, being resident in some parts of the country throughout the year, it is nevertheless affected by the laws of migration even within the limited area of the British Islands.

In Scotland and the North of England, as well as in some parts of Ireland, it nests regularly every year, selecting the lonely moors and mountain-sides, where it remains from April to August, until the young are strong upon the wing. Towards the end of the latter month large flocks begin to congregate and gradually move southwards, to 
spend the winter on the open marshes and wastes, or on the coast, where there is a greater certainty of finding food.

It is in the winter plumage (as shown in the accompanying woodcut) that the Golden Plover is best known to the wild-fowl shooter, by whom it is eagerly sought after, both for sport and profit. The gregarious habits of this bird in winter often lead to large numbers being killed at a single shot, while the estimation in which it is held as an article of food is a sufficient inducement to take some trouble to procure it.

During the winter months Golden Plovers may often be found consorting with Peewits and Fieldfares, and feeding on the same diet; but, independently of their size, they may always be distinguished when on the ground at a distance by their peculiar motion, running with short quick steps and stopping abruptly; now and then dipping down the head to seize a worm, and elevating the tail considerably.

In enclosed districts they are generally to be found on the fallows, where they devour large quantities of earthworms; but they are particularly 
partial to flooded meadows and the soft ooze of our tidal harbours. In the meadows they find

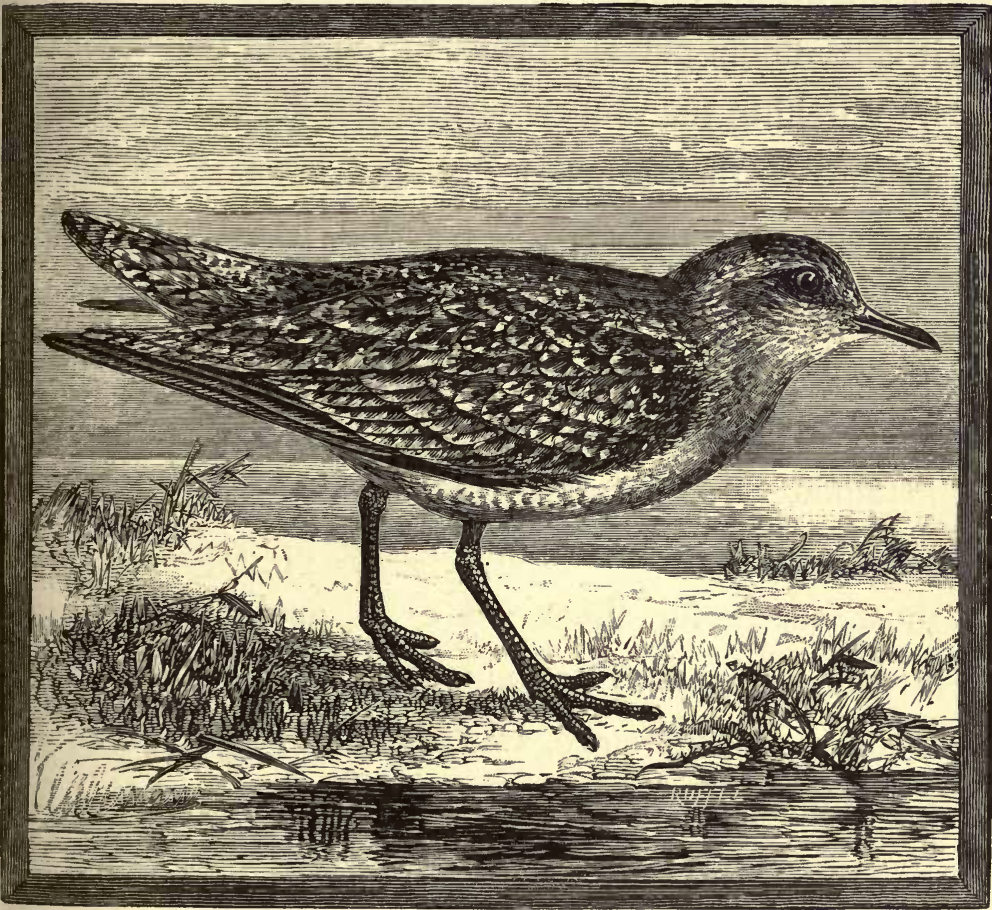

THE GOLDEN PLOVER.

abundance of insect and vegetable food; on the ooze their diet consists chiefly of small mollusca of various kinds and the fry of the common mussel.

At the approach of rain the flocks become very restless, wheeling about to and fro, and constantly 
shifting their ground. On this account it is said that the specific name of pluvialis has been applied to the bird, and, in some parts of the country where it is common, persons profess to foretell the weather by watching the movements of the flocks. So long as the weather remains fine and open these birds are uncommonly wary, but a dull, rainy day seems to take away all their energy, and they sit huddled together, with their heads drawn in between their shoulders, looking at a little distance more like inanimate clods of earth than birds. As on these occasions they are more easily approached, the most successful shots we ever made at Golden Plover were always obtained on a wet day; and it would seem, therefore, as if there were good reason for the saying that the bird is called pluvier in France, "parce-quion le prend mieux en temps pluvieux qu'en mulle autre saison."

"There is, in shooting Plover, a common remark made by sportsmen, that the second is always the most productive barrel. The rapidity with which they vary their position when on the ground seldom admits of a grand combination for a sitting, or rather a running, shot. But when on the wing 
their mode of flight is most favourable for permitting the shot to tell; and it is by no means unusual to bring down a number. When disturbed they frequently wheel back directly above the fowler, and offer a tempting mark, if he should have a barrel in reserve; and even when too high for the shot to take effect I have often thrown away a random fire; for the Plover, on hearing the report, directly make a sweep downwards on the wing, and I have by this means brought them within range of the second barrel." 1

Thompson, in referring to this singular habit of the Golden Plover, ${ }^{2}$ gives an amusing anecdote on the subject, as related to him by a friend.

"In the winter of I847 I went to some boggy meadows in the neighbourhood of Belfast, for the purpose of shooting Golden Plover, and took with me a young lad who had never before been on such an expedition. When returning home a flock, consisting of about fifty of these birds, flew overhead beyond reach of the shot; but as I despaired of getting nearer to them, I fired at the flock,

1 Wild Sports of the West, vol. ii. p. 235.

${ }^{2}$ Nat. Hist. of Ireland - "Birds," vol. ii. p. 88. 
on which they instantly swept down, almost perpendicularly, within three or four yards of the ground. My companion ran forward in the greatest delight, to pick up, as he expected, the entire flock, when, to his utter amazement, they all resumed their former mode of flight, and quickly disappeared in the distance."

Towards the end of March or beginning of April, the large flocks break up, and smaller parties may be observed moving northwards again towards their breeding haunts. About this time sundry black feathers make their appearance on the throat and breast, giving indications of that remarkable change from winter to summer plumage, when the underparts, from being pure white, become jet-black.

We shall not easily forget the first occasion on which we met with the Golden Plover in summer plumage.

Walking, in the middle of May, over a wild moor in Northumberland, where the eye rested on nothing but heather and sky, we were watching the circling flight of a Curlew, and wondering whether we could find the nest. Suddenly we were almost startled by a soft, clear whistle, which 
sounded so close at hand that we turned round, expecting to find a follower who might have some message to deliver. Nothing was to be seen, and while we gazed and wondered, again it sounded clear and plaintive, bringing to mind those lines of Sir Walter Scott, in the Lady of the Lake-

"And in the Plover's shrilly strain, The signal whistle's heard again."

There was something very ventriloquial in the sound, and it was a long time before we were able to determine the exact direction whence it proceeded. At length having decided this, and concluding that it must be a Golden Plover, although the note differed from the well-known call which we had so often heard in winter, we went down on hands and knees and crawled stealthily towards the spot where we supposed the bird to be, stopping now and then to listen for the guiding call.

So fully convinced were we that the bird was at least a hundred yards ahead, that it was with considerable surprise we came upon it before we had accomplished half that distance.

We can conceive few emotions more pleasurable than that which sways the mind of a naturalist 
when looking upon a species which is new to him; and we shall never forget the delight which we experienced on that occasion, when, peering through the heather, we saw for the first time, within ten yards of us, a black-breasted Golden Plover. Although so many years ago, we can still recall every attitude of the bird as we first saw it. The uplifted wing and short quick run, as if for a meditated flight, and then the sudden repose and motionless attitude, on finding that no danger threatened. We watched it till our eyes swam, when another came in view, announcing its presence by a soft whistle exactly similar to that we had heard before.

Our curiosity satisfied, we rose to our feet and both birds took wing. Soon we saw a third and a fourth, and picking up the almost forgotten gun, began to think of securing one or two specimens for closer examination. This we had no difficulty in doing, for the birds were by no means wild. We concluded from their actions, and from the early date, that they had not yet commenced to nest; and this conclusion was strengthened by the fact that we searched a large tract of ground for more than three hours without finding any eggs. 
The two specimens which we carried home had not quite assumed their full summer dress, there being still a few white feathers cropping out upon the underparts. The stomachs of both contained a number of little shining beetles, and a few small univalves, of which we could not then determine the species.

At this time of year, May, the whistle of the Golden Plover seemed unceasing, and proceeded from the birds while on the ground; but in the winter we have never remarked these birds to call much except when disturbed and on the wing. Their plaintive note upon a lonely moor or mountain-side has something indescribably wild and pleasurable about it, and we never hear it without feeling, like Burns, an elevation of soul like the enthusiasm of devotion or poetry.

Cowper, in his Winter Walk at Noon, says :-

"There is in souls a sympathy with sounds, And as the mind is pitch'd, the ear is pleased With melting airs and martial, brisk or grave; Some chord in unison with what we hear Is touch'd within us, and the heart replies."

How often have we proved the truth of this! 
Had we remained later on the moor referred to, we should in all probability have been rewarded by finding the eggs, since we have been assured that the Golden Plover breeds there annually. The nest is a very slight affair, not unlike that of the Peewit, and the eggs also are very similar to the Peewit's eggs, although larger and more richly coloured.

The young when first hatched are remarkably pretty little things, being powdered over, as it were, with golden yellow upon a brown and gray ground-colour. They run as soon as they leave the shell, and fly well by the end of July. The family parties then unite in August, and begin to form those dense flocks to which we have already referred, and which are looked for in winter with such eagerness by sportsmen in the south. 


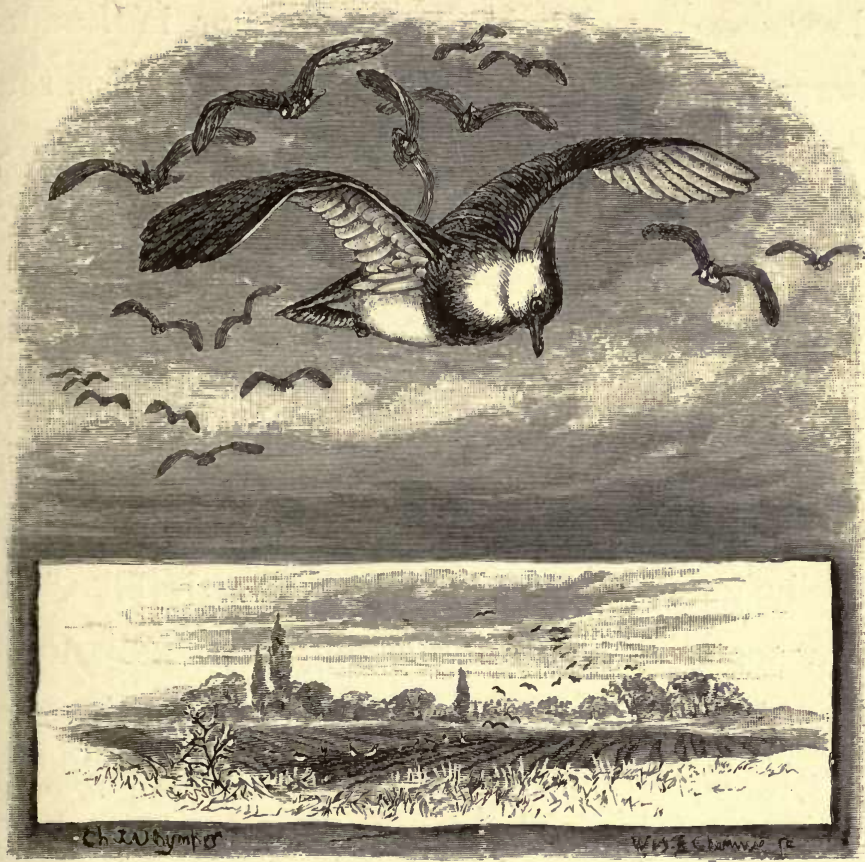

\section{THE PEEWIT, OR LAPWING.}

VANELLUS CRISTATUS.

Most people have tasted Plovers' eggs, or at least have heard of them. They are in season in May, and may be obtained from any of the London poulterers for four shillings the dozen. "Rather dear," you 
will say, when you can get four times the number of hens' eggs for the same money. True, but Plovers do not lay in farmyards, nor in London mews; and if people will have such delicacies, they must pay a price proportionate to the difficulty of procuring them. After all, they do not always get what they pay for, since, from not knowing a Plover's egg when they see it, they frequently buy eggs of the Redshank, Reeve, Black-tailed Godwit, and even of the Black-headed Gull, instead of the genuine article. But what matter? They are all equally good, and "where ignorance is bliss," we have some authority for saying "'tis folly to be otherwise!" It is the fashion to have Plovers' eggs in the season, and when boiled hard with the shells off, who is to say they are not Plovers' eggs?

We have often been amused with the observations of our young lady friends who sometimes pay a visit to our museum. On going to the egg cabinet with a laudable desire to know something of oology, one of the first remarks is, "Have you got any Plovers' eggs?" and on being shown a drawer full of Golden Plover, Lapwing, Dotterel, etc., they are fairly puzzled to say which are the 
eggs they had at supper the other night. This difficulty overcome, the next question is, "Which is the Plover that lays these eggs?" We have only to point to the pretty graceful Peewit, to elicit a chorus of praise in its favour. The long crestfeathers, glossy green back, black breast, and white underparts, relieved by the chestnut undertailcoverts, combined with a certain pertness of expression, render it a very attractive bird.

What pleasant associations are recalled as we gaze at it! The rough meadow where we first found the eggs, as a boy, and watched with delight the wonderful evolutions of the parent birds, as with plaintive cry they wheeled and tumbled in the air before us. The oozy mud-flats, with the intersecting creeks, down which we urged our punt in May and August after Curlew, Godwit, and Gray Plover-the mud there was sometimes black with Peewits! The brown and purple moor-side, where we found the Peewit in the midst of Grouse, Curlew, Golden Plover, and other north-country friends. The quaking bog, where in winter we have shot now a Peewit, now a Snipe, and the next minute missed a Jack. The old pollard in the water meadow, 
where we used to wait at night for ducks, and on blank nights make up for a disappointment by bagging Peewits. Such are the scenes which it is one of the chief pleasures of the naturalist to recall when looking at a bird in his collection.

The Peewit may be considered a resident species, for it may be found in some part or other of the country all the year round. There is no doubt that great numbers move southwards at the approach of winter; and the birds which we notice in the southern counties in the fall of the year are probably visitors from more northern localities.

In many parts of the country we have remarked that the same ground is annually resorted to by Peewits for the purpose of nesting; and hence we may conclude that the same birds return year by year, impelled by curious instinct, to the very spot where they have formerly reared their young. They pair towards the end of March, and early in April collect straws and dry grass, and form a slight nest in a depression of the ground. When the full complement of eggs is laid, each nest contains four, and the harvest time for poulterers and game-dealers commences about the middle of April. When the 
locality which the birds have selected has been discovered, dozens of eggs may be picked up on a few acres, for Peewits are gregarious in their habits, and the nests are frequently only a few yards apart. The eggs, which are considerably pointed at the smaller end, seldom vary much in colour, being olive-brown, spotted and splashed towards the larger end with black, or dark umber. We have once or twice taken eggs of this species which were of a pale stone-colour, with small black spots at the larger end. These strikingly resemble very large eggs of the Ringed Plover (Agialitis hiaticula), and afford an illustration of the fact that some birds, while usually laying eggs peculiar in colour to their own species, occasionally lay eggs which resemble those of other species in the same family. We have noticed this in many cases.

The young Peewits are very active as soon as they are hatched, and as they leave the nest at the approach of an enemy, and cower down close to the ground, the mottled brown colour of their backs renders it very difficult to catch sight of them in this position. In this way, no doubt, they often escape destruction. 
The food of the Peewit is, to a great extent, insectivorous. The stomachs of a great many of these birds which we have shot and examined on grass-land upon a clay soil, were filled with different species of small Coleoptera, and minute particles of grit; while others, which we procured on down-land upon a chalk soil, contained fragments of two Mollusca which are extremely common in such situations,-Helix virgata and Helix caperata. It is the Helix caperata, by the way, which, being taken up with grass by sheep, is said to impart the excellent flavour to the South-down mutton. Judging by the condition of the Peewits which had fed upon this mollusc, we should say that its properties are very fattening.

When the birds get down to the shore, they lose their flavour, and are then not nearly so good for the table. We have noticed this in the case of the Curlew, Golden Plover, Gray Plover, Redshank, and many others besides the Lapwing. The reason of this, no doubt, is the change in their diet. On the shore they get sand-hoppers, shrimps, and other small Crustacea, which impart more or less a marine and disagreeable flavour. 
As the name "Peewit" has been given to the bird from its peculiar note, so has the name "Lapwing" reference to its characteristic flight.

Those who live in the country must have noticed how appropriately both these names have been applied. In some places the bird is known as the "Green Plover" in spring, and the "Black Plover" in winter. At the approach of the nesting season the back and scapulars become of a dark but bright metallic-green colour. In the winter this colour becomes darker and duller, until at a little distance it looks almost black.

We know few sights more engaging than a flock of Peewits on their breeding-ground, where the eye is pleased with their graceful actions and curious evolutions on the wing, while the ear is charmed with their strange, long-drawn notes. Happy the man who lives near the resort of these birds, and who, listening to " nature's sweet sounds," can hear amid the well-known caw of the Rook and the gentle murmuring of the Wood-pigeon, the plaintive cry of " Pee-wit." 


\title{
THE WOODCOCK.
}

\author{
SCOLOPAX RUSTICULA.
}

Not many years ago it was currently believed by sportsmen that no Woodcocks remained in the British Islands after the end of winter, except perhaps a few wounded birds, which were unable to cross the sea to their usual breeding-places. Nor is this notion yet altogether exploded, so difficult is it to controvert preconceived ideas which have once firmly taken hold of the public mind.

It is, of course, perfectly true that the greater proportion of the Woodcocks which are found here by sportsmen during the shooting season are winter visitants, which arrive in October, and which, if not killed, would leave the country again in March or early in April. But it is equally the fact that a large number of Woodcocks annually remain here to pair and nest in suitable localities. 
Mr. A. G. More, in his valuable remarks in The Ibis, "On the Distribution of Birds in Great Britain during the Nesting Season," observes that the nest of the Woodcock is by no means so rare as is generally supposed. The bird is reported as breeding occasionally in nearly every county throughout England and the south of Scotland. Farther north it becomes more numerous, and may be considered to breed regularly from Perthshire northwards to Caithness. ${ }^{1}$ There is no doubt that many more birds remain to breed now than formerly; and this increase appears to be owing to the great extent of country which has been covered with plantations during the past few years, particularly, according to St. John, with fir plantations. ${ }^{2}$

What reason, asks Selby, is to be assigned for this change in their habits? Is it to be attributed to a change in our seasons, or are we to look for it in the great increase of woods or plantations, so general over all the island, affording these birds

1 Mr. More might also have added Ireland, since several instances of the Woodcock breeding there are mentioned by Thompson (vol. ii. p. 247), and many others have since been recorded.

2 Wild Sports and Natural History of the Highlands, p. 264 (ed. 1878). 
additional and secure retreats, as well as an abundant and constant supply of food ? ${ }^{1}$ The late Sir William Jardine attributed the circumstance to the increased attention paid to Ornithology, and to such facts being recorded; he could not perceive any change in the country to induce the birds to remain more frequently than heretofore. ${ }^{2}$ Another reason may be found in the circumstance that now many owners and lessees of manors do not allow their coverts to be disturbed in the spring, and give orders to their keepers to spare the Woodcocks after a certain date.

Mr. T. Monk, of Lewes, some years since, was at considerable pains to obtain statistics as to the number of Woodcocks remaining to breed in the eastern division of Sussex; and, extraordinary as it may appear, the conclusion he arrived at was to the effect that in seven districts of East Sussex, comprising twenty-one parishes, there were annually, on an average, from one hundred and fifty to two hundred nests of this bird. ${ }^{3}$

1 Magazine of Zoology and Botany, vol. i. p. 201.

${ }^{2}$ British Birds, vol. iii. p. I7 I (Naturalist's Library).

3 The statistics here referred to were published in The Field of 25th February 187 I. 
It is not, however, with the question of nesting that we are now concerned, but with the singular habit which this bird has of carrying its young under certain circumstances - a habit which has been placed beyond doubt by the testimony of many competent observers, and which has been very beautifully depicted by Mr. Wolf in the accompanying illustration. The observation of this habit is by no means new. Scopoli, in his Annus Primus Historico-Naturalis, long ago remarked upon it, and several writers since his time have discussed the subject. Gilbert White, on reading Scopoli's statement "pullos rostro portat fugiens ab hoste," was incredulous. " But candour," he added, "forbids me to say absolutely that any fact is false, because I have never been witness to such a fact. I have only to remark that the long unwieldy bill of the Woodcock is perhaps the worst adapted of any among the winged creation for such a feat of natural affection." Had Scopoli omitted the word "rostro" his statement might have been less open to criticism, the fact being that not one of the subsequent observers who have confirmed his assertion that Woodcocks do carry their young, agrees with him 
that they are carried in the bill. Nor do they upon this point agree amongst themselves.

The late L. Lloyd, in his Scandinavian Adventures, wrote:- "If in shooting you meet with a brood of Woodcocks, and the young ones cannot fly, the old bird takes them separately between her feet, and flies from the dogs with a moaning cry." Again, in his Game Birds and Wildfowl of Sweden and Norway (p. 194), he thus refers to the habit as observed by a friend :- " ' Once during a hare-hunt,' writes my friend, M. Anders Oterdahl, 'I myself shot a Woodcock, flushed by the dogs, and when flying at about six feet from the ground, that was bearing an unfledged young one in her claws. It seemed to me she grasped it with her feet, one foot having hold of one wing and the other foot of the other. Though, owing to intervening branches, I did not observe the old bird when she rose, I was fortunately so near to her as clearly to see what I have stated. Afterwards I found two other young ones under a neighbouring bush, where they had retreated for safety.' When the above story appeared in my former work, Scandinavian Adventures, it was looked on by many, both in Sweden and 


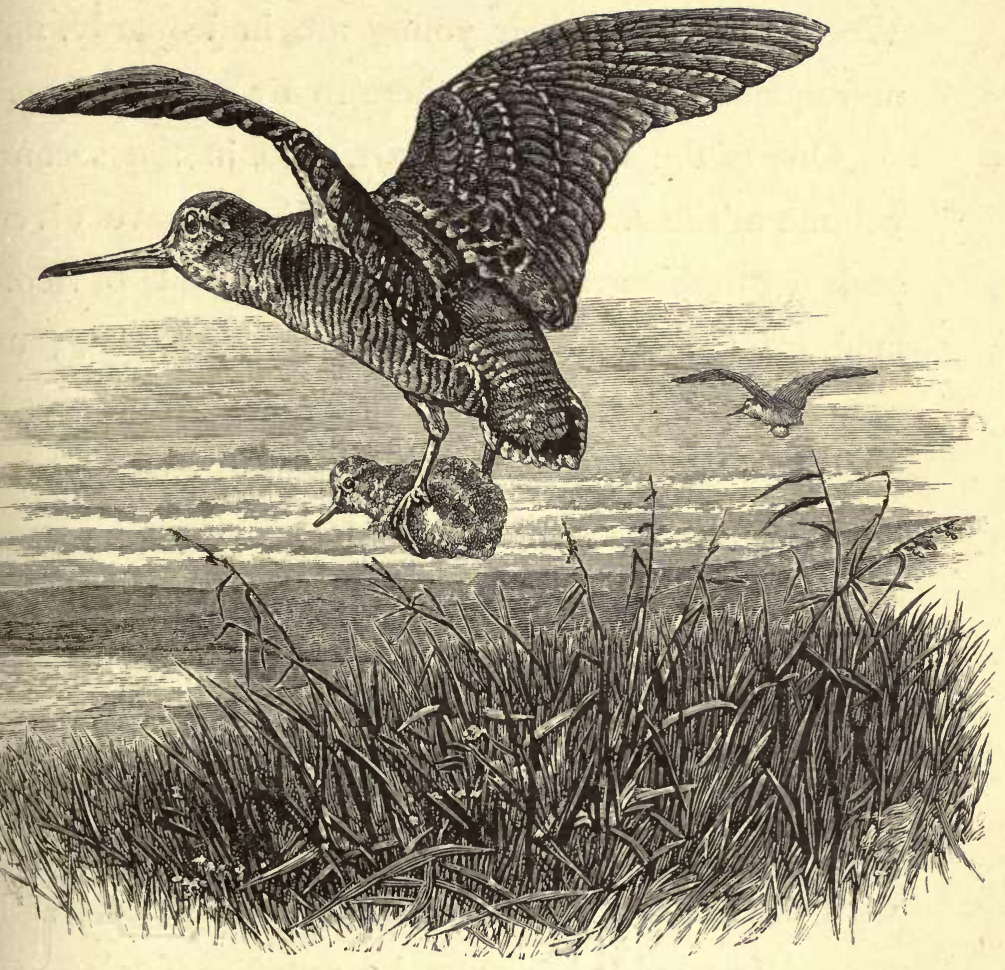

THE WOODCOCK. 
England, as a fable; but, from the number of similar instances since recorded, it is now, I believe, received as an admitted fact in both countries that Woodcocks, when their young are in jeopardy, not unfrequently thus convey them to a place of safety."

One of the brothers Stuart, who, in the second volume of the Lays of the Deer Forest, have given such a graphic account of the wild animals of Scotland, from personal observation of their habits, thus refers to the bird now under discussion :-

" The Woodcock breeds to a considerable extent in most parts of the forest, and also in other woods of Morayshire, the Aird of Inverness, and on the Dee, the Don, the Spey, and other parts of the Highlands; but, within our knowledge, nowhere so numerously as in Tarnaway. Without any search, and merely in the accidental occasions of roe-hunting, we have found, in one season, nineteen nests with eggs. It would, however, be more proper to say 'beds,' rather than ' nests;' for, like those of the Plover, they are merely slight hollows formed by the nestling of the bird's breast in dry soft spots, or on the fallen leaves. They generally lay three eggs, sometimes four, and occasionally, but rarely, 
five; and never, that we have known, beyond that number. The eggs are surprisingly large in proportion to the bird, and of a brown colour, variegated, like the young, with beautiful clouded tints. Like all the larger ground-birds, they run as soon as they are hatched, which is early in the spring; and in May I found a brood of five, so large that I could only catch the smallest, and that with difficulty. As the nests are laid on dry ground, and often at a distance from moisture, in the latter case, as soon as the young are hatched, the old bird will sometimes carry them in her claws to the nearest spring or green stripe. In the same manner, when in danger, she will rescue those which she can lift. Of this we have had frequent opportunities for observation in Tarnaway. Various times, when the hounds, in beating the ground, have come upon a brood, we have seen the old bird rise with a young one in her claws, and carry it fifty or a hundred yards away; and, if followed to the place where she pitched, she has repeated the transportation until too much harassed. In any sudden alarm she will act in the same way. One morning I had been sitting for some time on the gray stone of the 'Braigh-clach- 
liath,' ruminating with my eye fixed unconsciously on the ground, at the dry leafy foot of a cluster of those tall slender birches which, at that time, formed one of the most beautiful features of the terrace; as my thoughts became less intense, and the mind had exhausted its action upon the subject by which it had been abstracted, the eye grew more sensible, and I was aware of another large black eye which was fixed upon mine from the bed of brown leaves before me. I could distinguish no form, no colour distinct from them; in fact, the leaves seemed to look at me. I approached nearer and nearer, but could discover nothing but the large, round, dark eye fixed intently upon mine. I was at a loss what to think : if the eye closed, I felt that there would be nothing left to prove that what I then saw was one of the clearest and most intelligent eyes I had ever beheld, when suddenly the little, round, lightbrown head of a young Woodcock peeped out from what now became visible as the back of its mother, whose eye it was which had caused me so much astonishment. The little head disappeared again, and immediately afterwards the diminutive bird came out from the feathers of the old one's breast, 
bearing half its shell upon its back, and uttering that plaintive cry for which language has no sign. I retreated softly to my stone, but trod upon a long dead branch which lay concealed under the moss, and the extremity stirring the leaves and dry sticks near the Woodcock, she rose, and trailing her wings along the ground, pattered round the stump of the birches, but stopped as she heard the wail of the little bird, which was running about like a tiny ball of brown chenille. In the nest there were two more eggs unhatched, but out of one I saw a little sharp bill and half of another small head peeping through the shell, and to relieve the anxiety of the madre, therefore, I immediately turned from her retreat, and dived down the terrace into the wood. Near the place where I found her there was a soft green 'stripe,' such as Woodcocks love. I had no doubt the family would be there next day; and as I passed near I turned aside to see what they were doing. Upon a dry bank, half-way down the brae, I almost stumbled over a bird which rose at my feet; and as it darted through the trees I saw that it had something in its claws, and at the same time I heard the plaintive cry of the little Woodcocks just 
under my feet. I looked down; there were two; and I thought a hawk had carried off the third, and perhaps killed the mother. I saw the bird light, as hawks very often do, especially in a close wood, when they have just caught their prey, and are impatient to satisfy their appetite. I sprang down the bank, determined, if I could not save the little victim, to spoil the hawk's breakfast. I flushed the bird so suddenly, that, after a low flight of only a few yards, it dropped what it was carrying, and instantly lighted not half-a-dozen paces distant. I ran to pick up the mangled prey, when to my surprise I found a vigorous little Woodcock running about as nimble and active as its madre could wish. I looked for the hawk, but in his stead saw the old Woodcock, in great consternation, trailing her wings as if wounded, and busy to attract my notice. As soon as I followed she led me away, hirpling and halting like an 'old wife,' taking little flights, which became longer as she drew me farther; till at last, thinking she had sufficiently succeeded, she took a turn down the brae, rose over the trees, and wheeling back dropped on the spot where she had left her charge. I gave her a little time to find 
him, which was not difficult, as he continued to call her as loud as his tiny bill could pipe. In a few moments I ran forward, and she rose with him in her feet, her long legs dangling and swinging with her little burden like a parachute. She lighted at no great distance, and as I again came upon her she got up, but in her hurry dropped the young bird. I instantly stopped, for she came to the ground almost at the same time with the little one, and she ran back and sat upon him, and rose again with him in her claws. I left her to pursue her flight in peace, and went on to my pass; but I have no doubt she went back for the other two, for, several times afterwards, I saw them all together in the soft green 'glac.'"

This very circumstantial account from so good an observer leaves no room for doubt in the mind of the reader, but an independent observation by another equally good naturalist may be quoted for the purpose of showing that the young are carried in another and a different manner to that already described, and that they are thus transported, not only to escape their enemies, but for the purpose of obtaining food, which, in their unfledged state, they 
would be unable to procure at any distance from the nest. Charles St. John, in his Natural History and Sport in Moray (p. 210), says :-

"I have again seen the old Woodcocks carrying their young down to the soft, marshy places to feed. Unfitted as their feet appear to be for grasping anything, the old birds must have no slight labour in carrying their whole family (generally consisting of four) every evening to the marshes, and back again in the morning. They always return before sunrise. Occasionally I have come upon a brood of young Woodcocks in a dark, quiet, swampy part of the woods, near which they have probably been bred. In a case of the kind we may suppose that the old birds are saved the trouble of conveying their young to a distant feeding-place; but as the young birds are frequently hatched in long heather in dry situations, and far from any marshes, they would inevitably perish in the nest were they not daily carried backwards and forwards by their parents. The quantity of worms required to sustain one of these birds would astonish those town-bred naturalists who gravely assert that the Woodcock 'lives on suction.' ... As soon as the 
young are hatched, the old birds are obliged to carry them to the feeding-ground, which is often at some distance. The young, though able to run immediately, are tender helpless little things, and could by no means scramble through the tangled heather and herbage which often surround their nest, perhaps for many hundred yards. It long puzzled me how this portage was effected. That the old birds carried their young I had long since ascertained, having often seen them in the months of April and May in the act of doing so, as they flew towards nightfall from the woods down to the swamps in the low grounds. From close observation, however, I found out that the old Woodcock carries her young, even when larger than a Snipe, not in her claws, which seem quite incapable of holding up any weight, but by clasping the little bird tightly between her thighs, and so holding it tight towards her own body. In the summer and spring evenings the Woodcocks may be seen so employed passing to and fro, and uttering a gentle cry, on their way from the woods to the marshes. They not only carry their young to feed, but also, if the brood is suddenly come upon in the daytime, the old 
bird lifts up one of her young, flies off with it fifty or sixty yards, drops it quietly, and flies silently on. The little bird immediately runs a few yards, and then squats flat on the ground amongst the dead leaves, or whatever the ground is covered with. The parent soon returns to the rest of her brood, and if the danger still threatens her, she lifts up and carries away another young bird in the same manner. I saw this take place on the I8th May; the young were then larger than, or fully as large as, a Snipe."

Here it will be observed that the narrator doubts the feasibility of any other mode of transport than that which he himself witnessed.

Thompson, in his Natural History of Ireland ("Birds," vol. ii. p. 253), refers to a keeper who believed that he had seen the old hen carrying off her young when suddenly disturbed. Under the impression of his having been deceived in the matter, he several times followed hens apparently thus burthened to where they alighted, and saw them run off without any young bird being there. It is, he says, the body behind the wings, the tail, legs, and feathers of the belly, that she droops down in a 
peculiar manner, that gives the appearance of a young bird being clutched up. He was several times quite near to birds presenting the appearance here described.

St. John's account of the mode of transport, however, has been confirmed by other observers. A correspondent writing from Rostrevor, Co. Down, in August 1871, says :- "On the 2d of this month I started a brace of Woodcocks close to me. One of them had a young one pressed between its breast and feet; it lighted on the ground again after rising, apparently to get a better grasp of its young one, and then flew off with it. They were near the edge of a wood in the afternoon and during sunshine." Another correspondent, writing from Rohallion, Birnam, says:- “This spring (187I) I have been witness repeatedly to the ability of the Woodcock to carry its young, and fly off with them, pressed to its body by its legs. This was in May and June."

Another method of transport is that referred to by Mr. W. Colquhoun (Dumbartonshire), who says:- "I have seen a Woodcock carry its young, but it was by pressing it between its legs."

Again, Mr. A. Hamond jun., of Westacre, in- 
formed Mr. Stevenson that when in company with a friend and a gamekeeper, at Shielda, near Dingwall, in Ross-shire, he saw a Woodcock in the act of carrying a young one in its claws for some distance. The old bird then returned and clucked about like a hen to draw the rest of the brood to her. His friend had observed the same proceeding on several occasions. ${ }^{1}$

Thus it is placed beyond doubt that the Woodcock is able to transport its young, in various positions, from place to place, not only when flying from its enemies, but also when going out to feed and returning.

This curious habit is not confined to the European Woodcock, but, according to Audubon and others, has been observed also in the American species. More recently, too, it has been witnessed in England in the case of the Common Snipe. A well-known sportsman, who has adopted the pseudonym of "Idstone," writing in The Field of 3oth May 1874 , says that on the $22 \mathrm{~d}$ of the same month, when crossing a marsh on his way to a trout stream, a Snipe rose almost at his feet, "and there 1 The Birds of Norfolk, vol. ii. pp. 292, 293. 
was attached to it, mostly on its left or near side, a young Snipe, which it carried, or which clung to it, for about twenty-five yards." He could distinctly see the markings on the young one, and is therefore positive that he was not mistaken. The locality was close to Laurence's Mill, Morden, Dorsetshire. In the same number of The Field, Mr. John Titterton, of Ely, Cambridgeshire, states that a similar thing was observed near Ely, also in May of the same year.

These observations confirm our impression that, while the old birds are able to carry their young in two or three different positions, that which has been so skilfully depicted by Mr. Wolf, in the accompanying engraving, is probably the one most commonly employed.

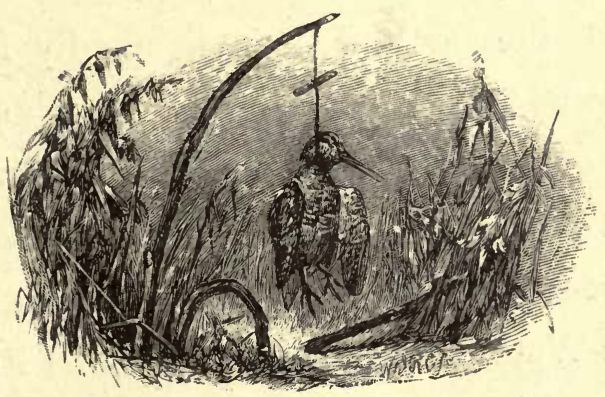




\section{THE RUFF AND REEVE.}

MACHETES PUGNAX.

Whit a host of rare birds are conjured up in the mind of the ornithologist at the bare mention of the fens! - the great fens of Lincoln, Cambridge, and Norfolk, which once covered such an immense tract of country, and which were seldom invaded by any one except the inveterate sportsman, whom neither bog nor water could deter, or the crafty fowler, whose life depended upon his trade.

Here the long-winged, long-tailed Harriers quartered the ground uninterruptedly for miles, pouncing upon the young Teal or Shoveller, or carrying off, from the very surface of the water, the unwary Spotted Crake before it could dive. Here the Short-eared Owl reared its young, and brought them fat Water-shrews and Short-tailed Field-mice. Here the Bittern "boomed" as it crept amongst 
the sedge, and wove and shaped the pliant flags to receive its olive-brown eggs. Redshanks flew in clouds, and filled the air with their noisy cries, while the loud whistle of the Godwit often told the fowler where the long-legged, black-tailed bird had formed its nest. On the "meres," the beautiful Crested Grebe displayed its coloured frill and white satiny breast, while its smaller relative, the Dabchick, like a little brown ball, ducked and dived and reappeared in the uninterrupted enjoyment of its retirement. The wary Water-rail threaded its way through the grass and reeds and sedge, or rose with slowly flapping wing, and pitched among the yellow water-lilies, to pick the little beetles off the petals.

The ear heard, although the eye could not always see, the skulking Grasshopper Warbler, as it crept amongst the reed stems with its curious reeling note: and a patient search was necessary to find its well-concealed and pretty nest at the foot of some waving tussock. Occasionally, the nest of the rarer Savi's Warbler was discovered; a beautiful cup-shaped structure, made entirely of the interwoven leaves of the reed, and containing beautiful 
pinky-looking eggs. More conspicuously, the Bearded Titmouse showed himself as he flitted from stem to stem, or crossed the water with an undulating jerky flight, uttering as he went his ringing tinkling notes.

We have heard an old sportsman say that, more than forty years ago, when searching these fens for the large Copper Butterfly (Chrysophanus dispar) and other rare insects, he frequently saw the nests and eggs of all these birds; and the children of the fen-men used to bring him in hatfuls of eggs of the Harriers, Short-eared Owl, Great Crested Grebe, Black-tailed Godwit, and Spotted Crake. Fancy, buying a hatful of Spotted Crake's eggs for sixpence, or half a dozen fresh Bittern's eggs for a shilling! What rare days for the ornithologist! But they are passed away! The great fens are drained, and have almost ceased to deserve the name. The beautiful birds which once haunted them, finding no longer the same retirement and opportunities for nesting, have disappeared. Some, as residents, are now extinct, and we see them only at particular seasons of the year, when, as if to try another chance of nesting here, they revisit the 


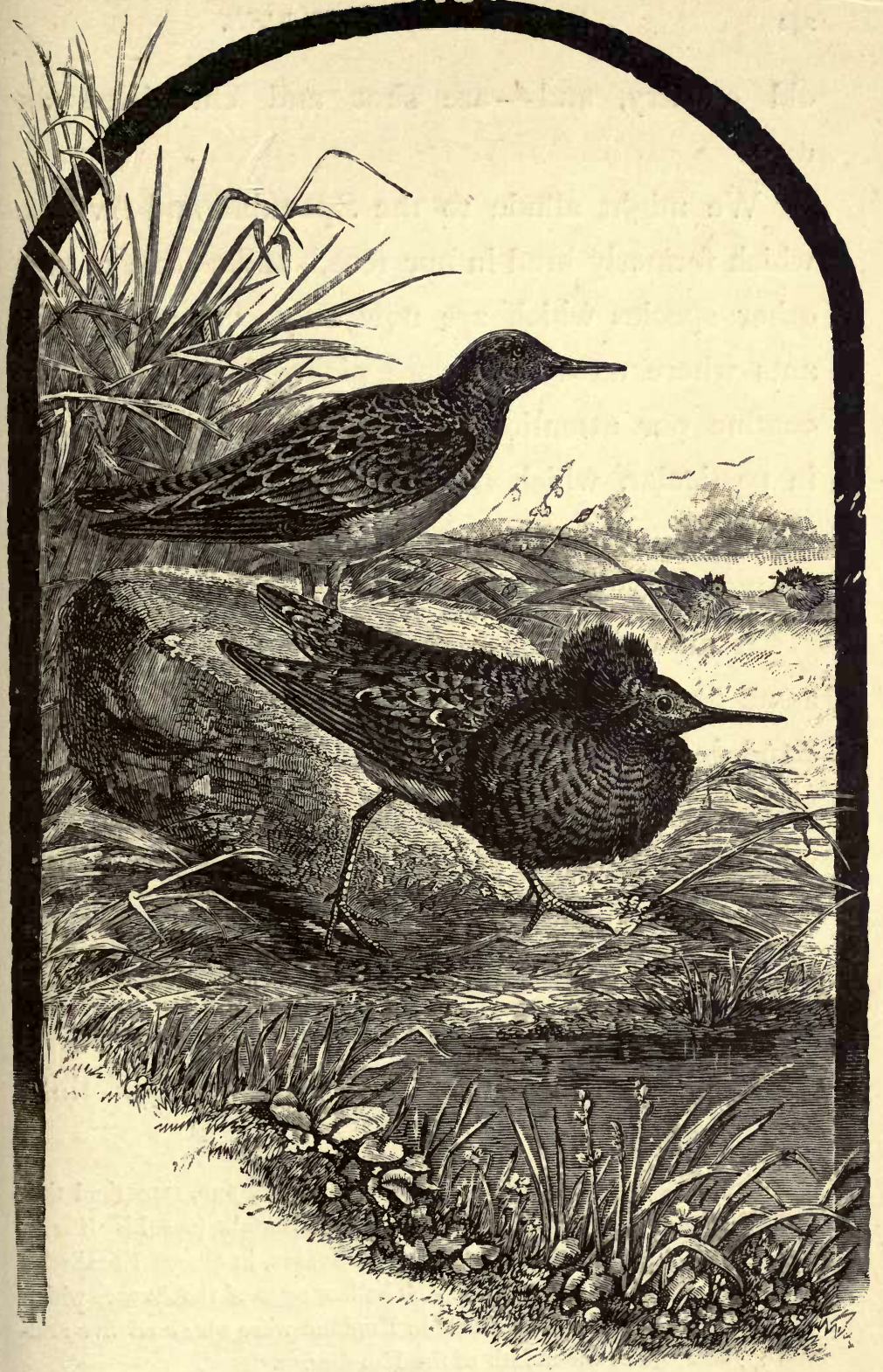

THE RUFF AND REEVE. 
old country, and-are shot and chronicled as rare!

We might allude to the Spoonbill and Avocet, which formerly bred in our fens, ${ }^{1}$ and to one or two other species which are now only occasional visitants where once they were plentiful. But we will confine our attention for the present to one bird in particular, which may be now almost placed in the same catalogue - the Ruff, and his mate, the Reeve.

A most singular bird this is. Belonging to the same great group which comprises the Snipes and Sandpipers (Scolopax, Tringa, and Totanus), it differs remarkably from them all in many respects. Old naturalists placed it among the Tringe, but as the species became better known, it was found that, unlike any other wading bird, the males were polygamous, and fought for possession of the females ; differed from each other in colour; were a third

I Sir Thomas Browne, writing two centuries ago, remarked that the Spoonbill then nested in Norfolk and Suffolk (see his Works, Wilkin's Ed., iv. p. 315), as it did also in Sussex, in Queen Elizabeth's time (see Zoologist, 1877, p. 425). The last eggs of the Avocet which are recorded to have been taken in England were obtained five-andthirty years ago at the mouth of the Humber. 
larger than their mates; and during the breeding season put forth a curious frill of feathers on the neck, which disappeared in autumn when the sexes separated. These facts led naturalists to consider the bird generically distinct from those above named, and it is now generally placed in the genus Machetes, which Cuvier, in 1817 , proposed for it.

By far the most complete account which has been given of the Ruff and Reeve is that which was published by Montagu, in 1813 , in the supplement to his Ornithological Dictionary. This distinguished naturalist travelled from Devonshire into Lincolnshire-a long journey in those days-with the sole object of studying these birds in their native fens, and of ascertaining more than was then known of their habits and curious change of plumage. $\mathrm{He}$ experienced the greatest difficulty in discovering the haunts of these birds, for the fen-men, who made a trade of snaring them for the table, refused to give him any information on the subject, fearing lest their trade might be interfered with. $\mathrm{He}$ attained his object, nevertheless, and carried back with him several live Ruffs to Devonshire. These he kept in confinement for a few years, and care- 
fully noted all the changes of plumage which they underwent, and the peculiarities of habit which they displayed. His interesting remarks on the subject should be read in extenso by every naturalist.

The male birds, as the name Machetes implies, are extremely pugnacious, and this is especially the case at the commencement of the breeding season when the birds are pairing. Two Ruffs will then contend for the possession of a Reeve, and with heads lowered, frill distended, and wings trailing the ground, they rush at one another again and again, like game-cocks, leaping and striking with the bill, until one or other is forced to yield. Having paired and selected a spot for the nest, they build not unlike a Snipe, and in much the same situations, generally choosing the middle of a tussock or clump of sedge. Here they lay four eggs of an oil-green colour, blotched, chiefly at the larger end, with liver brown. In size and shape the eggs are equal to those of the Redshank, but may be distinguished as follows: the Redshank's egg looks as if it were painted in water-colour, has a lighter ground-colour, and smaller markings on it. The Reeve's egg has a more oily look and feel, the texture is smoother, 
the ground-colour generally greener, and the blotches thereon larger.

It is a remarkable thing that we seldom see two Ruffs of the same colour; the variety is surprising. As a rule, the male bird renews the same coloured frill in each succeeding year. This has been proved repeatedly by marking birds in confinement and noting their changes of plumage; but it has occasionally happened that a Ruff which had a light frill one year, assumed one of a darker shade the succeeding spring. The frill begins to make its appearance in April, and before the end of July it has almost disappeared. This bird appears to have a wide geographical range. We have specimens in our collection from Southern Russia, Nubia, and the Cape of Good Hope. Great numbers are imported every spring from Holland, and may be seen in most of the poulterers' stalls, especially in Leadenhall market. They are considered great delicacies for the table, and generally fetch from fifteen to eighteen pence apiece.

At that season of the year the Ruff and Reeve are now seldom met with in England, for, as we have observed, their breeding haunts have been 
almost destroyed. Mr. Stevenson says that in East Norfolk a few pairs still breed annually, and are strictly preserved. In Suffolk, Cambridgeshire, and Yorkshire, where this species was once plentiful, it has now ceased to breed, and in the more northern counties of Durham and Northumberland a nest is very rarely found. We have lately been informed that a few pairs have been found nesting in Lincolnshire within the last two years.

During the months of August and September, at which season great numbers of shore-birds migrate southwards, the Ruff and Reeve are more commonly met with.

We have found them at this time of year in the tidal harbours on the east and south coasts, and have several times shot them when looking for Snipe in marshy ground near the sea. More rarely we have seen them in autumn on the Brent, within a few miles of London. The males had then lost their frills, and were only to be distinguished from the females by their larger size and darker plumage. The colour of the legs varies almost as much as the colour of the frills. Orange, lemon, clay colour, lead colour, and black may be found, with all the 
intervening shades, and this difference of colour in the legs as well as in the plumage led some of the older naturalists to create much confusion by describing different individuals as distinct species.

The practice of netting this bird for the table in the spring of the year, after the pairing has commenced, is most reprehensible. To destroy the breeding grounds, and kill the old birds is a sure way to exterminate a species, and yet this is what is being done in the case of the Ruff and Reeve. We would earnestly beg of those who may meet with these birds in suitable localities for nesting, in the spring of the year, to leave them unmolested, and not to cause another name to be added to the list of beautiful birds which have already become extinct as residents in this country. 


\section{THE CURLEW.}

NUMENIUS ARQUATA.

Авочт the end of July, or beginning of August, great numbers of shore birds come into our harbours, and find their way from the mouths of the rivers to a considerable distance inland. Gray Plovers, Godwits, Knots, Whimbrel, Greenshanks, Redshanks, Dunlin, and many other "waders," continue to arrive until the end of August, and the shores and mud-flats which were so deserted during the summer while the birds were away nesting, now present a most animated appearance. Flocks of various species, and of various sizes and colours, from the tiny brown Stint (Tringa minuta) to the great gray Heron, are scattered over the ground in all directions; now feeding busily as they follow the receding tide, now flying with noisy call to some more attractive spot. As we look down upon them 


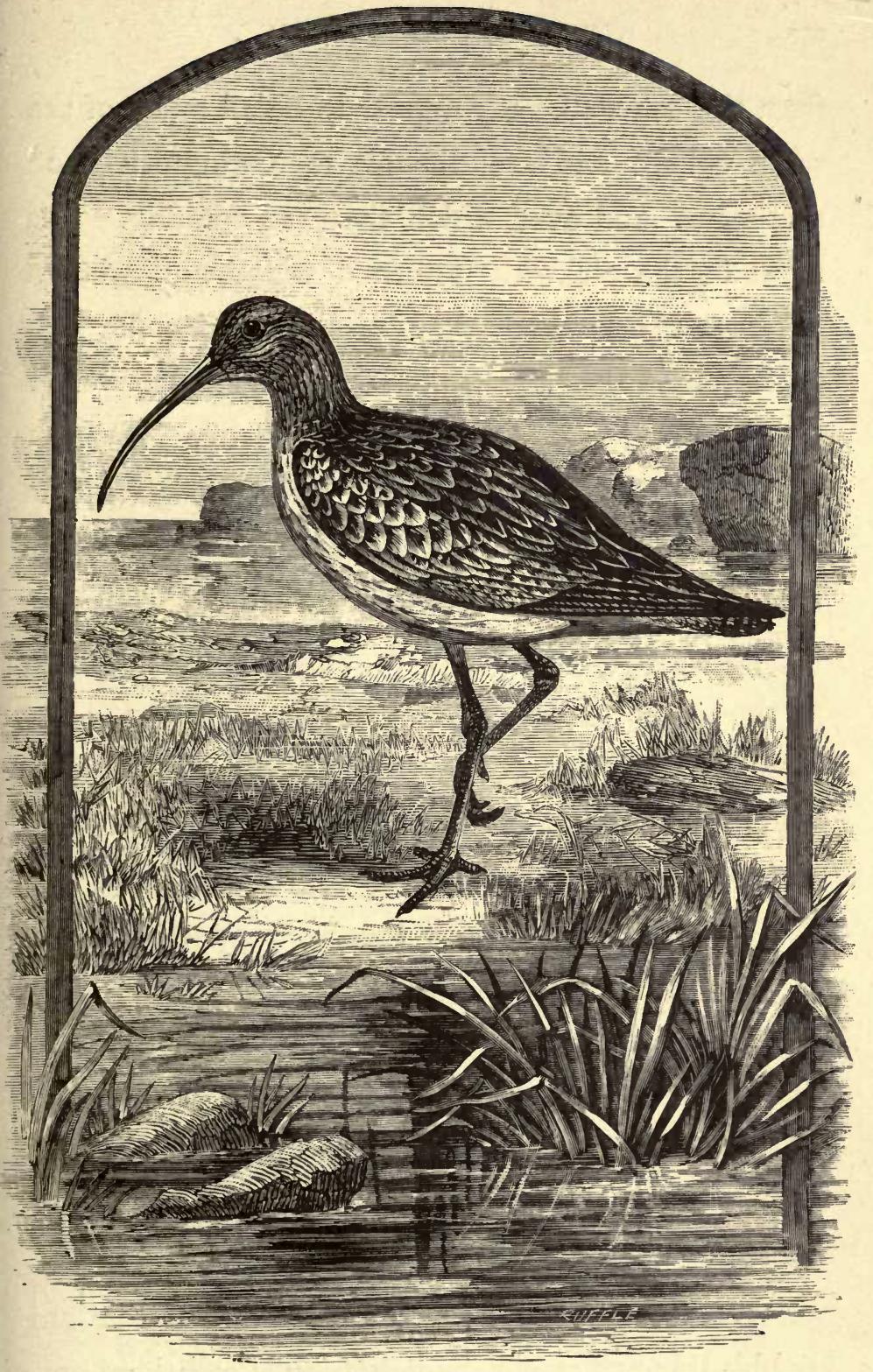

THE CURLEW. 
from the sea-wall, they appear to be all much of the same colour, and are difficult to distinguish upon the brown mud over which they are running. See them in the air with upturned wings, and what a different appearance they present. As the sun strikes upon the pure white of the underparts borne swiftly onwards by rapid wings, the eye is almost dazzled at the bright contrast. Individuals are soon lost to sight as they fly closer together, and the entire flock, gradually lengthening out, sweep across the harbour like a long wave, now light, now dark, as the under or upper portions of the plumage are presented to view. Naturalists who visit the seaside at the period of migration to which we have alluded, cannot fail to admire the wonderful and graceful evolutions which these birds perform upon the wing; whilst those who reside upon the coast throughout the year must hail with satisfaction the arrival of these feathered strangers, whose presence adds so much to the beauty of the scenery, and relieves, to such an extent, the monotony of sea and sky.

We have always had a partiality for "lang nebbit things," as our Scotch friends call them, not- 
withstanding the supposed connection between a long bill and a suspicious character, ${ }^{1}$ and have experienced more real enjoyment in the pursuit of them than many who have never tried it would suppose. To one who is fond of shooting, the various kinds of Sandpipers afford much sport at a time when game is not in season. They fly like Snipe, and require some little exercise of skill to bring them down, especially if crossing rapidly from right to left, or vice versâ. Then, they are excellent eating, and are therefore not useless when killed, like many species of sea-birds. Again, to the inquiring naturalist, their various plumages and the seasonal change which each undergoes, their actions and habits, the nature of their food, the different appearance of different species at a distance when on the ground and in the air, the various calls and alarm-notes, afford an endless source of amusement.

The greater portion of the flocks which visit us in autumn consists of young birds which are on their way southwards for the winter. The old birds are seen on their way to the north in May, and after an absence of six or eight weeks they return with their ${ }^{1}$ See Sir Walter Scott's Black Dwarf, chap. ii. 
young as soon as the latter are able to fly. The majority of our shore birds annually perform this double migration; but there are many species which remain in limited numbers to nest in this country. Amongst these are the Golden Plover, the Ringed Plover, the Oyster-catcher, the common Sandpiper, the Dunlin, and the Curlew.

The Ringed Plover and the Oyster-catcher remain near the shore, and lay their eggs upon the sand or shingle, as the case may be. The common Sandpiper betakes itself to the north country burnsides, and generally makes its nest at no great distance from the water; while the Golden Plover, Dunlin, and Curlew go on to the moors and peatbogs, and bring up their young in the wildest and most unfrequented spots.

When walking over the moors in May we have repeatedly startled a Curlew from amongst the tall heather, and have satisfied ourselves on these, as on other occasions, that this wary bird depends more upon the sense of sight than hearing to save itself from its enemies. Ever suspicious, ever on the alert, it is a most difficult bird to stalk unless some good cover intervenes to screen your approach. 
Now and then upon the coast you may steal a march upon a flock under shelter of a sea-wall; but, as a rule, they keep too far out from the shore to be within reach of a gun from the wall. We have found it a good plan to "lay up" at a spot in the usual line of flight about an hour before high water. As soon as the mud is covered, they leave the harbour, calling loudly at intervals to one another as they fly, and by imitating their call, while lying concealed, we have repeatedly brought a Curlew overhead and within shot. Another plan is to go down the harbour in a gunning-punt, with an ordinary double gun, at low water, and work along the numerous channels which intersect the great mud flats. In this way you can often get, unperceivedly, within shot of a flock of birds, and secure even the wary Curlew.

On one occasion we were lying in a punt in "a drain" (as the small channels in the Sussex harbours are called) a little below a point where another "drain" intersected it almost at right angles. In the latter we had marked down two Curlews when several hundred yards off, and observed that they were feeding towards the junction of the two 
"drains." It is always a piece of luck, if birds feed towards you after you have got as near to them as you can without alarming them. And this was the case in the present instance. The Curlews waded up the side of the drain, which was much shallower than the one we were lying in, and in about ten minutes one of them stepped out upon the flat within twenty yards of the punt, and for a moment seemed perfectly scared. We at once cocked the gun and sat up; with a weird scream the bird took wing, and in another second fell dead upon the mud. His companion rising out of the drain some yards further off, was only winged, and led us a rare chase over the ooze before he was secured. This incident shows that the Curlew depends for safety upon his keen sight, and not upon his power of scent, otherwise the bird in question would never have walked within a few yards of the punt, which he could not see until he had stepped upon the bank.

In the Zoologist for $1856, \mathrm{Mr}$. W. H. Power has given an account of the way in which the fishermen at Rainham, in Kent, decoy Curlews within shot. They train a red-coloured dog (as much like a fox as possible) to prowl about and attract the attention 
of the birds while the gunner lies hidden in a dyke. As soon as the birds chase the dog, which they frequently will do, he draws gradually towards his master, until a shot is obtained. Sometimes two or three Curlews are killed at a time in this way; but the plan is said not to answer with a flock. We can confirm its success, however, with a single bird, for we once killed a Heron which we should never have got near, had not a red setter attracted its attention, and on being whistled to, brought up the bird within shot.

Those who have had much experience in shoreshooting must have remarked how much Curlews differ in size. Whether this difference is dependent upon age or sex is a point still discussed. We have hitherto been inclined to believe that the variation is owing to age; but as this conclusion has been drawn chiefly from external appearances, and in a few instances only from dissection (for we generally eat all the Curlews we get), and as in the case of other waders-for example, the Bartailed Godwit -the female has proved to be invariably larger than the male, it is possible that the same rule may hold good with the Curlew. 
The note of the Curlew is by far the loudest uttered by any of our grallatorial birds. That observant naturalist William Thompson says, in his Natural History of Ireland ("Birds," vol. ii. p. 195): "It will perhaps be scarcely credited that it can be heard at the distance of nearly three English miles; yet under peculiar circumstances such is the case. I have heard it so on calm moonlight nights when at the extremity of the bay at Holywood Warren, awaiting the flight of these birds from Harrison's Bay and Conswater, whence the flowing tide would drive them from particular banks respectively two and three miles distant from any station. The call from the first-named locality sounded quite near, and from the latter distinct, though much more faintly; the state of the tide at the time evincing with certainty that all the banks except the two alluded two were covered too deeply with water for the birds to be on them.. Shore-shooters are well aware of this circumstance."

Besides its usual cry of "Cou-r-lieu, cour-lieu," there is another which sounds like "wha-up;" from which latter cry the bird in Scotland has derived the name of "Whaup;" and in the spring of the year, 
when pairing, a softer note is frequently heard, which sounds like "whee-ou, whee-ou."

The food of the Curlew is very miscellaneous, consisting of all sorts of marine mollusca and crustacea, worms, small fish, and vegetable matter, invariably accompanied with a quantity of sand or small particles of grit. The bird is especially fond of small shore crabs, and we have sometimes killed a Curlew so gorged with crabs and shrimps as to be offensive to the smell and quite unfit for food. On sandy shores the Curlew lives principally on cockles, which it swallows whole, and we have been astonished sometimes at the size of the shells which we have taken out of the stomach. It would scarcely be supposed that a cockle-shell of the diameter of a shilling could pass down the gullet of a Curlew, yet we have found recently-swallowed shells of this size still unbroken in the gizzard.

Those who are familiar with the works of Professor Wilson must remember his admirable description of the feelings which he experienced when stalking a Curlew." "At first sight of his long bill aloft above the rushes, we could hear our heart beating

${ }^{1}$ Recreations of Christopher North, vol. i. p. 36 (1 864). 
quick time in the desert; at the turning of his neck, the body being yet still, our heart ceased to beat altogether-and we grew sick with hope when near enough to see the wild beauty of his eye. Unfolded, like a thought, was then the brown silence of the shy creature's ample wings, and with a warning cry he wheeled away upon the wind, unharmed by our ineffectual hail, seen falling far short of the deceptive distance, while his mate, that had lain couched perhaps in her nest of eggs or young, exposed yet hidden - within killing range, half running, half flying, flapped herself into flight, simulating lame leg and wounded wing; and the two disappearing together behind the hills, left us in our vain reason thwarted by instinct, to resume with live hopes, rising out of the ashes of the dead, our daily disappointed quest over the houseless mosses. Yet now and then to our steady aim the bill of the 'Whaup' disgorged blood, and as we felt the feathers in our hand, and from tip to tip felt the outstretched wings, fortune, we felt, had no better boon to bestow, earth no greater triumph." Who has not at one time or other experienced feelings such as these, and lacked the power of words to describe them? 


\section{THE HERON.}

ARDEA CINEREA.

As we traverse the marsh with dog and gun, in pursuit of Snipe, we may almost depend upon seeing a Heron, but seldom indeed can we get near enough to take a good look at him; his long neck and equally long legs enable him to keep such a sharp look-out that on the least approach of danger he unfolds his broad wings, and first flapping for some yards along the ground, he rises slowly into the air, and sails away to a safer haunt. But should you detect him at a distance before he sees you, there is a chance of your being able to stalk him, especially should he happen to be in the bed of a river, or stream. It will often require as much tact and exertion to approach a heron as to stalk a deer; but should you succeed in getting near him unperceivedly, you will be amply repaid in observing his 
movements, and may finally bring him to bag, and study him at table with lemon and cayenne. We speak from experience. We have made many a successful stalk, and can confidently state that a young Heron, nicely roasted, with the adjuncts above named, forms a dish by no means to be despised.

On most parts of the coast the Heron may be seen at low-water, fishing in the little pools which have been left by the receding tide: here he finds crabs, shrimps, and other delicacies; but instead of being sociable, like the Gulls and Redshanks, and inviting a friend to join him at dinner, he goes to his own particular pool, like an old gourmand to his club, and keeps the best of everything to himself.

We have watched him on the rocky weed-covered shore of Northumberland, on the shining sands of Lancashire, and on the dreary mud-flats of the Sussex harbours, and have found him always the same; shy and suspicious, even where seldom disturbed, he seems to have a wonderful eye to danger, and we almost believe can distinguish a gun from a stick or an umbrella.

Now and then upon a rocky coast, we have stalked him under cover of a friendly boulder, and 
while our heart beat loud with the rapid exertion and excitement, we have shot him just as he had detected our head above the rock. And what a triumph have we felt in standing over his prostrate form, and smoothing his expansive wings, feeling in that moment a sufficient reward for having crawled on hands and knees, perhaps three hundred yards of treacherous ground, slipping over sea-weed, and through salt-water pools. But it was never thus on the mud-flats; there no friendly barrier intervened to screen our approach, and we could only advance near enough to be just out of shot, when the large wings were unfolded, and we were left to stand and gaze wistfully after the coveted prize. Now and then at early dawn, we have come suddenly upon a Heron while busily employed under the steep bank of a brook, and have thus been enabled to knock him down with snipe-shot before he could get out of range. It was ludicrous to observe the surprise of the bird when he first became aware of our presence, and with a hoarse croak clumsily endeavoured to get away. On one occasion, accompanied by a red setter, we were stalking a Heron, when the dog, over-anxious, ran forward and attracted the attention 
of the bird, which immediately took wing; instead of flying away, however, he hovered over the dog, looking down at him like a hawk. We crouched down and gave a low whistle, and the dog, coming back, actually brought up the Heron within shot, when we fired and killed him. The bird seemed to follow every movement of the dog, and was so intently eyeing him, that he never saw us until the gun was raised; he then turned at once to make off, but too late.

On the coast, the Heron feeds at low water during the day, and in unfrequented marshes he may also be caught fishing in broad daylight; but when compelled to get his living at reservoirs, ponds, and rivers, which are oftener visited by his enemy, man, he prefers to come just before daybreak or after dusk. In autumn, when the brooks run dry, we have frequently noticed the impressions of his long toes, visible for miles on the soft mud, showing the great extent of ground traversed in his patient search for food. Fish, frogs, mussels, and even water-rats, are all included in the Heron's bill of fare. He will take young water-fowl too from the nest, and after pinching them all over in his formid- 
able bill, and holding them under water till they have become well saturated, he throws up his head, opens his mandibles, and the "Moorhen souché" disappears.

Some years ago we paid a visit in the month of

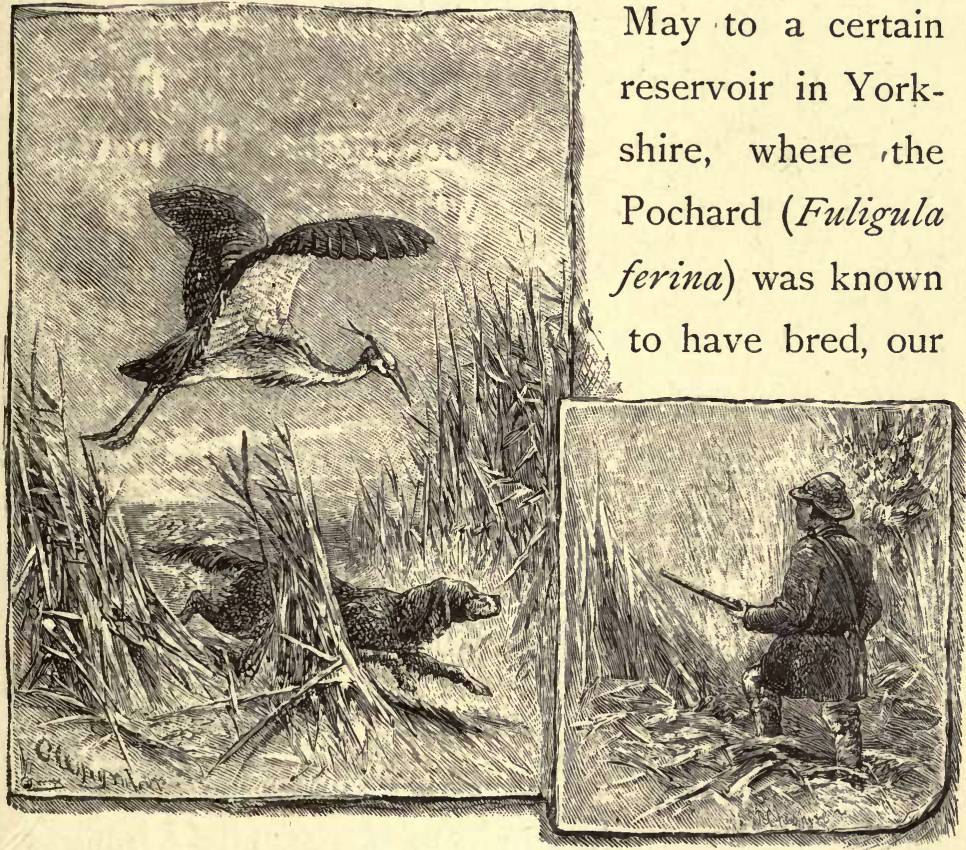

object being to ascertain whether this duck was then nesting there, and to learn what other fowl were on the water. We might say a good deal of that pleasant excursion, but must confine our attention for the present to the Heron. At one end 
of the reservoir is, or was, a thick bed of willows, extending out some distance from the shore. The water at this spot is shallow, with a muddy bottom. Coots and Moorhens were numerous and noisy, swimming about amongst the willows, and collecting materials for their nests. We lay upon the grass at the edge of the water, peering quietly through the willows, and learnt a good deal of the private life of these water-fowl. While we were gazing, a Heron, which must have flown unnoticed up the water, dropped suddenly in the shallow, within twenty yards of our ambush. Here was an opportunity for observation : scarcely venturing to breathe, we watched with interest every motion of the great gray bird. His long black crest and pendent breast feathers showed him to be fully adult, and we thought at the time we had seldom seen a Heron in finer plumage. With head and neck erect, he took a cautious glance all round, as if to satisfy himself that he was unobserved, and apparently assured, he then looked down at the water; for some minutes he never altered his position, till at length, bending slowly and gracefully forward, he suddenly struck the water with his bill, and recovered a small fish. 
A pinch, a toss of the head, and it had disappeared down his throat. He then drew himself together with apparent satisfaction, wiped his bill upon his long breast plumes, and slightly altering his position, prepared, as an angler would say, to make another "cast." At this moment we incautiously moved a little to one side to avoid a willow bough and obtain a better view, when his quick eye instantly detected the movement, and in another second he was flying down the water in the direction whence he had come.

There are few sights more gratifying to a naturalist than a heronry. We have had the privilege of visiting several-one at Walton Hall, Yorkshire, the seat of the late Charles Waterton; another at Milton, near Peterborough, belonging to the Hon. G. Fitzwilliam; a third at Parham Park, Sussex, the seat of Lord Zouch; and a fourth at Wanstead Park, the property of Lord Cowley. ${ }^{1}$ Did space permit, we might give an interesting account

${ }^{1}$ Some years ago an attempt was made to ascertain the number of heronries existing in the British Islands, when it appeared, contrary to expectation, that there were at least 200 in different parts of the country. A list of these, first printed in The Field, was afterwards republished with additions in The Zoologist for 1872 . 
of what we saw on these occasions, but it will suffice if we describe the situation and general appearance of the heronry last named.

The date of our visit was the 5 th of April, and the birds were then sitting on their eggs. The Heron is one of the few waders which resort to a tree for the purpose of nidification, and a stranger sight than a number of these great birds perched at the top of a lofty elm, can scarcely be imagined. Twenty years ago, the Herons at Wanstead Park tenanted some trees at a different spot to that which they now frequent. At present they occupy some tall elms upon an island in the largest piece of water in the park. The keeper informed us that there were about thirty pairs. We proceeded to the boathouse, and after baling out the boat, which was nearly full of water, steered for the Herons' island. A good glass enabled us to see the birds very clearly, and most of them were in splendid plumage. The nests were placed at the very tops of the trees, and many of them were occupied by a sitting bird.

Here and there a Heron stood erect upon a bough, with head and neck drawn in, looking for all the world like a cold sentinel, with his bayonet be- 
tween his teeth, and his hands in his trousers pockets. As we approached the island several loud croaks were heard, and the sentinels took wing, the sitting birds being the last to leave. Taking it for granted that the bird which sat the longest was the most likely to have eggs, we selected a tree from which a Heron flew as we reached it.

It was a wych-elm about forty feet high, and the nest was placed amongst the topmost branches. After a fatiguing climb, owing to the absence of boughs for a considerable distance, we reached the top, and paused to rest before looking into the nest. And now was the anxious moment. Were our exertions in vain? Was the nest empty, or were we to be rewarded with the sight of eggs? The nest was large enough to sit in, composed externally of large twigs, chiefly elm and willow, and lined with smaller twigs, fibre, and dry grass. It overhung our head to some extent, so that we were obliged to pull away a portion of the side before we could see into it, when, to our delight, four beautiful eggs were displayed, their bright bluish-green colour contrasting well with the dark fibre on which they were laid.

The wind blew in gusts, and it was no easy 
matter to get them down safely; but at length we succeeded in getting them into our handkerchief, and, holding the ends together in our mouth, brought them down without a crack. They were considerably incubated, showing that they had probably been laid about the end of the third week in March. The Heron, indeed, is one of the earliest birds to breed. The young, when first hatched, present a very remarkable appearance, and are fed by their parents for a long time before they can shift for themselves.

A friend once kept a Heron on his lawn, and a very amusing bird he was. When first captured, he was very sulky, and refused all food. Fearing he would starve, the owner forced some fish down the bird's throat, but the next moment saw it returned upon the grass. The process was repeated with the same result, and a third time my friend endeavoured ineffectually to overcome the obstinacy of his captive. At length, reflecting how the Chinese treat their trained Cormorants, by fastening a strap round the neck to prevent the fish from going down, he tied a piece of tape round the Heron's neck, to prevent the fish, in this case, from coming up. The 
experiment was perfectly successful, and the bird, finding it impossible to disgorge, at length abandoned the attempt, and subsequently fed himself. Fish were placed for him in a fountain on the lawn, and he evinced great delight in taking them from the water. One day a rat was observed helping himself to the Heron's food. The rightful owner caught him in the act, and with one blow of his formidable bill felled him to the ground. Seizing him, then, before he could recover himself, he carried him squeaking to the fountain and ducked him. After shaking him well under water, he held him up for examination. The rat spluttered and squeaked in abject terror, and again was he submerged. The dose was repeated, until the unfortunate rat at length succumbed, and being by this time nice and tender, the Heron pouched him, and his then elongated form was seen distending the thin skin of the bird's neck in its passage downwards, until it finally disappeared altogether. 


\section{THE TEAL.}

QUERQUEDULA CRECCA.

OF all the prizes with which a wild-fowl shooter could wish to meet, a spring of Teal is amongst the first. Independently of their being by far the best birds of the whole duck tribe for the table, they are generally much easier to get at; and as they require but a slight blow to bring them down, it matters little what charge of shot is in the barrels.

The quiet rushy pools which lie at a distance from any road, the turf-holes on a peat-bog, and the sluggish shallow streams with overhanging vegetation, are the favourite haunts of the Teal. In some parts of the country this bird is resident throughout the year, but as a rule, and in the South of England especially, it can only be looked upon as a winter visitant. Of shy and retired habits, it shuns the more public ponds and rivers, and avoids the 


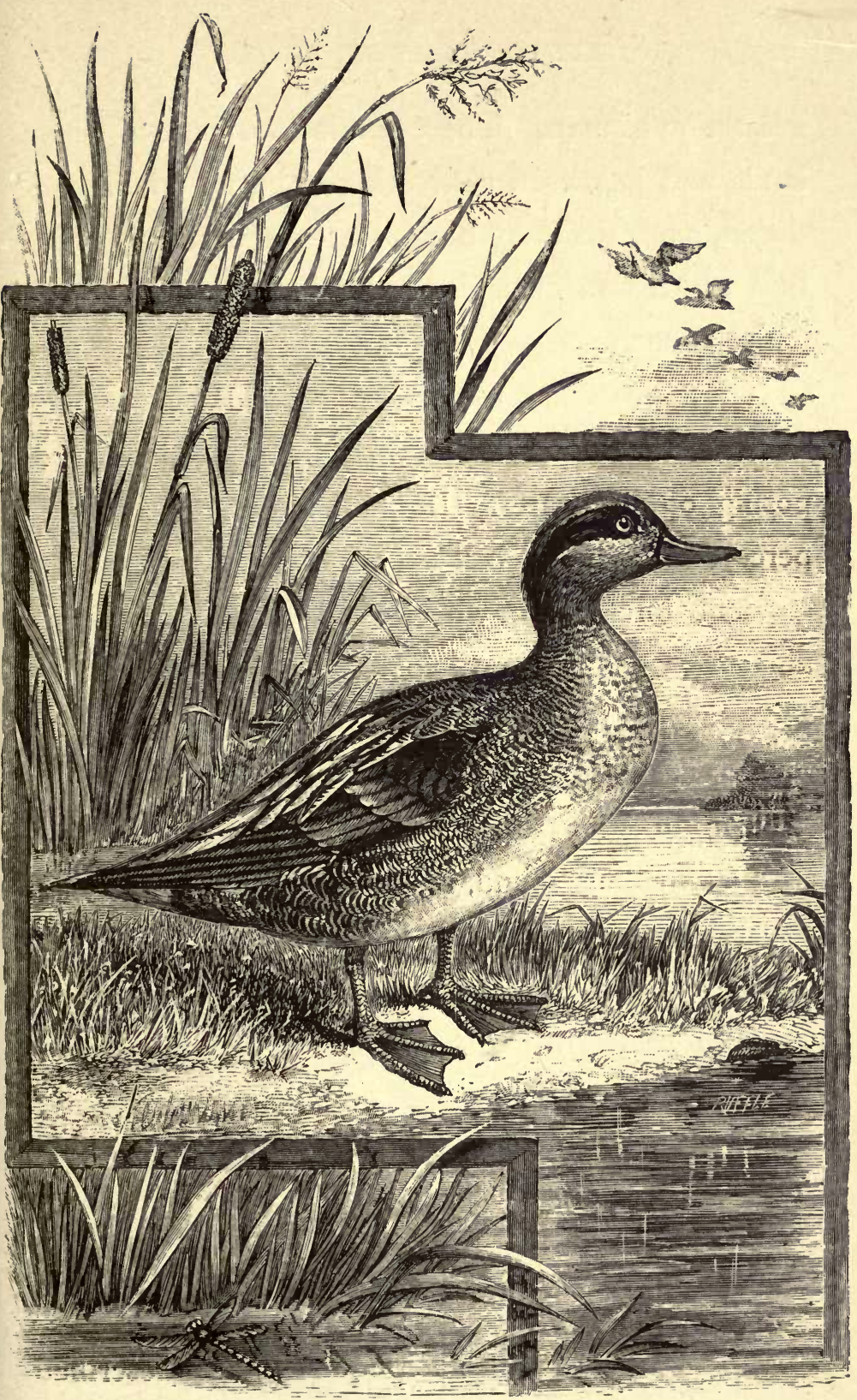

THE TEAL. 
habitation of man. The extended drainage of waste lands and increased cultivation have no doubt conduced more than anything else to the scarcity of a bird which was once plentifully distributed over the entire country.

On approaching the edge of a pond at a distance from a flock of Teal, they may be seen silently reposing on the water. Immediately the intruder is perceived, a harsh call is heard, and they spring suddenly into the air, wheeling round and about with amazing rapidity, now looking black, now white, according as the upper or under surface of their bodies is presented to the eye. Frequently, as though intending to alight, they fall through the air with a whistling sound, recovering themselves when apparently in the water, and rising again to a height. These manœuvres are repeated until the eye is strained in following them, and the whole flock at length settle down again in silence and repose as before. At such times it requires no small amount of caution to get near enough to them for a shot.

Col. Hawker, whose practical knowledge of wildfowl has rarely if ever been equalled, has described 
the habits of the Teal very accurately in his 'Instructions to Young Sportsmen.'

"If you spring a Teal, he will not soar up and leave the country, like a wild duck, but will most probably keep along the brook, like a sharp-flying Woodcock, and then drop suddenly down. But you must keep your eye on the place, as he is very apt to get up again, and fly to another spot before he will quietly settle. He will frequently, too, swim down stream the moment after he drops; so that if you do not cast your eye quickly that way, instead of continuing to look for him in one spot, he will probably catch sight of you and fly up, while your attention is directed to the wrong place. If the brook in which you find him is obscured by many trees, you had better direct your follower to make a large circle, and get ahead of, and watch him, in case he should slily skim away down the brook, and, by this means, escape from you altogether."

The female Teal, like the females of all the duck tribe, has little to recommend it in appearance, although the observant naturalist does not fail to notice that its dusky brown and gray plumage is peculiarly well adapted to its concealment during the time it is 
engaged in nesting. The cock Teal, on the other hand, has scarcely an equal amongst wildfowl for beauty of colouring. The chestnut head, with a patch of glossy green on each side, edged with buff; the neck, back, and flanks beautifully pencilled with black and gray; the bright green speculum on the wing, broadly bordered above and below with velvet black; and the black and buff under tail-coverts present to the eye a perfect picture of harmonising colour which defies the imitative pencil of the artist.

In July the old Teal moult, completely losing their quill-feathers, and are then for a time unable to fly. The males at this season undergo that remarkable change of plumage which has been observed in other ducks,-losing all the colours which are characteristic of their sex, and presenting a very sorry appearance in contrast with their spring dress. The young at this time are able to shift for themselves, for the Teal nests early in the year. We have several times found the eggs during the last week of April. Although usually placed in the vicinity of water, the nest is sometimes at a considerable distance from it, and always rests upon 
dry ground. We have never found a Teal's nest in the swampy situations in which Coots, Moorhens, and Grebes build.

A hollow is generally scraped out at the foot of some overhanging bunch of heather; or tussock of dry waving grass, and lined with fine heath-stalks and bents. Here eight or ten creamy-white eggs are laid, and as the hen covers them, she plucks from her breast and sides the soft brown down which underlies her feathers, and places it entirely round the eggs, filling up all the interstices, thus forming a warm bed for the young as soon as they leave the shell. The overhanging roof of grass or heather conceals from above the clutch of white eggs, which would otherwise be espied by the passing Crow, and assuredly be carried off by this thievish bird.

The old duck is very attentive to her young, leading them from the nest to the marsh, where they paddle about on the soft ground and shallow pools, snapping up flies and beetles with their tiny bills, and varying their meal with the seeds of aquatic plants. They swim and dive well almost as soon as hatched; but how they contrive to follow their parents through the long heather, and the 
tangled rank herbage of the marsh without getting lost, has always been to us a matter of wonder and admiration.

A remarkable instance of affection in a Teal came under our observation towards the close of a mild winter. We were shooting over a wild bit of country where Ducks, Teal, and Snipe abound, and remain annually to breed in limited numbers. A rare spot it was for the naturalist, who might there to his heart's content enjoy that varied description of shooting which to our mind is so preferable to every other branch of the sport. Treading on a patch of soft ground, away went three or four Snipe with loud squeaks in different directions. Down came one, and another was missed; before we could load two more had gone away. Picking up the product of the first barrel, we almost trod upon a Water-rail which rose close to us, and with long legs dangling down, flitted over the rushes towards the water. But so good a bird for the table could not be allowed to go, and so down it came, an easy shot, and was lost to sight amongst the rank herbage. Unfortunately it was only winged, and being without a dog that day, we spent ten minutes or 
a quarter of an hour vainly endeavouring to find it. Meantime, however, we had put up and brought down another Snipe, and caught a hasty view of a Moorhen as it scampered away through the flags. Having pretty well disturbed that particular spot, we moved on, not without regret at having left the Water-rail behind us. Walking towards the head of a pool where a thick growth of flags seemed to indicate the probable presence of wildfowl, we were barely in sight of the water before a fine old Mallard rose with loud quacks, and with outstretched neck and legs did his best to get away before a charge could reach him. But alas! he was doomed to die ; and as he tumbled upon the grass with a thump which made one's heart rejoice, a couple of Teal, alarmed at the report, sprang from the flags within a few yards of him.

The duck being the nearest received the contents of the remaining barrel, and fell dead upon the soft mud at the very edge of the water. While speculating upon our good luck, and putting in two fresh cartridges, the cock Teal, which had flown up to the other end of the pool when his mate fell, turned back, and after flying up and down several times 
with mournful notes, returned to the spot whence he rose, and pitched upon the mud close to the dead duck. Here he remained for some seconds, nodding his head and curtseying, as if about to take wing,-uttering a low note the while as if to entice away the duck, whom he appeared so loth to leave. We were so struck at this manifestation of affection that we could not find it in our heart to shoot at the poor bird, and as we moved on to pick up his mate, he rose and was again soon out of range.

It is not improbable that the mildness of the season induced these birds to pair earlier than usual, for at the time of year at which the above incident occurred, Teal and other wildfowl are generally found in flocks.

Large numbers of these birds pass southwards for the winter, repassing again in the spring on the way back to their breeding-haunts. In September and October they collect in large flocks, and, as they fly a good deal lower and closer together than most other ducks, several may be killed at once by a well-directed shot. This is especially the case if the shooter be in ambush close to the water which they frequent; but as their flight is exceedingly 
rapid, care should be taken to hold well in front of the leading bird.

Teal are very sociable in their habits, and during the winter they may often be found in company with the common Wild-ducks. But although they mingle together when on the water, on being disturbed the species always separate, the Teal going off in one flock, the ducks in another. On rising from the water they do not first swim away from the danger, or flutter over the surface as some fowl do, but jump suddenly into the air without warning, so that if you are approaching them in a punt and do not pull the trigger the moment you find that you are perceived by them, you will in all probability lose your chance of a shot.

During the winter months this species is frequently found on the coast in company with Widgeon, and large numbers are often killed at a single shot with a punt-gun.

The Teal, however, appears to prefer the neighbourhood of fresh water, and is certainly one of the most beautiful ornaments in the winter scenery of our ponds and brooks. 


\section{THE HERRING GULL.}

LARUS ARGENTATUS.

THERE is something very refreshing in the change from the inland to the littoral; and there must be few indeed who have not experienced that delightful flow of spirits and quickened pulsation which always supervene when we leave the hot and dry and dusty country, and are brought gradually within sight of the far-resounding sea.

As we are whirled along by the express, the country becomes more bare and open; the woods gradually disappear; the song-birds are left behind, and gulls and peewits take their place; while through the open window, in spite of dust and steam, a delicious briny air comes rushing in, which at once dispels all sense of fatigue, and makes us long to get out, and breathe, and live in it. How complete and grateful is the change which modern 


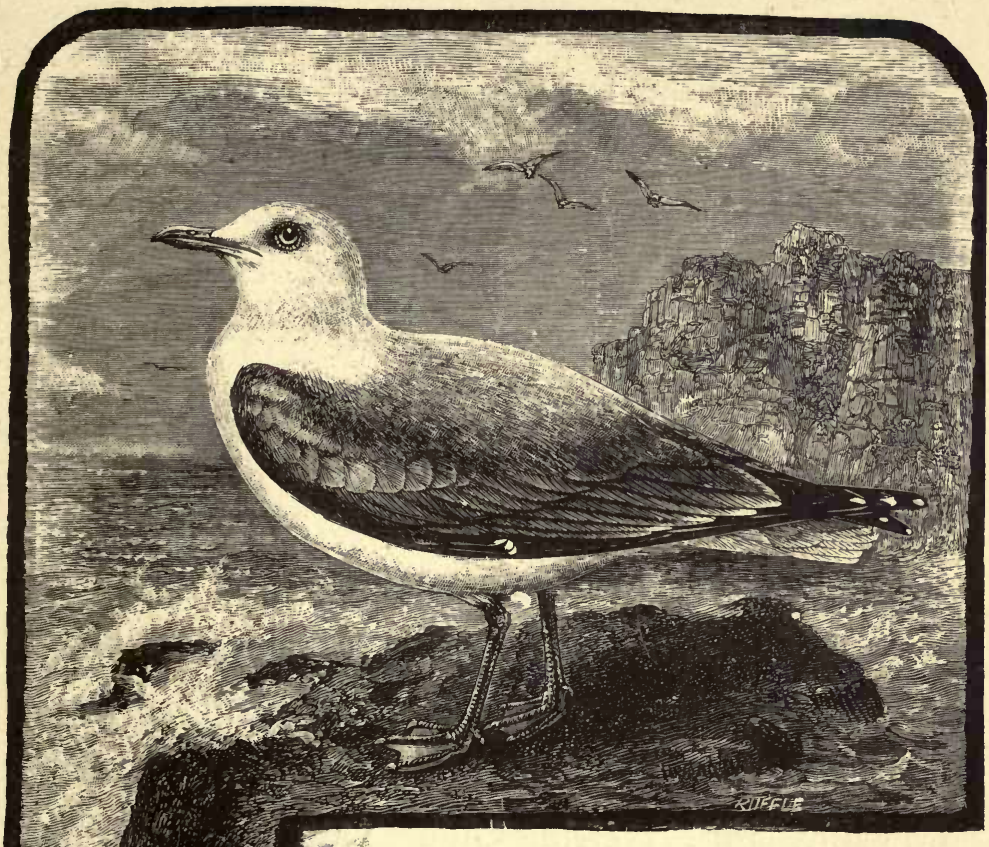

locomotion enables us to effect in a few hours! Yesterday, perhaps, we were walking down Bond Street, in all the discomfort of a London toilette, midst cabs and carriages, crowd and confusion. To-day we are sitting on the edge of Swyre Cliff, Dorsetshire, or on the summit of Beachy Head, dressed in an old shooting-coat and "wideawake," listening to the roar of waves, and the scream of gulls and guillemots! 
With new scenes come new thoughts, and we forget entirely the busy throng which we have so lately left behind, or think of it only to regret that we.must return to it. The birds, the sea-weeds, the insects, and the shells, in turn engross our attention, and we find occupation for a whole day in the study of a single species.

Almost as a matter of course the seafowl, by their cries and conspicuous plumage, attract especial notice, and to the ornithologist no greater treat can be afforded than a visit to one of their breedingstations during the time the birds are sitting.

The most widely-distributed of all the Gulls, probably, is the Herring Gull. During the nesting season this species may be found on all the rocky portions of our coast, but it is commoner on the west and south than on the east and north. Indeed, on the Welsh headlands, and throughout the entire range of cliffs from Cornwall to Sussex inclusively, this is the Gull most frequently met with. It is true the Greater Black-backed Gull (L. marinus) and the Kittiwake (L. tridactylus) are often found in the same cliffs with the Herring Gull ; but, except in favoured localities (as, for example, at Lundy 
Island, in the Bristol Channel), these two species, in the south at least, are in the minority in point of numbers, and the Lesser Black-backed Gull ( $L$. fuscus) is rare. Take a trip to Northumberland, the Farne Islands, and Holy Island, and you will find the case reversed. There the Kittiwake and Lesser Black-backed Gull are very numerous, and the Herring Gull is scarce. Farther north-that is, in Scotland-we meet with the Common Gull (L. canus) much more frequently than in England. The only other resident species of Gull to be mentioned is the Black-headed or Peewit Gull ( $L$. ridibundus). This bird, however, does not breed in the cliffs as the others do, but makes its nest inland on the ground, and differs materially from its congeners both in haunts and habits.

The appearance of certain Gulls when at a distance is very deceptive. The Herring Gull, Kittiwake, and Common Gull, are frequently confounded, from the similarity of their plumage and the difficulty in estimating their size, except when near enough to be within shot. It requires a good glass and a practised eye to identify them at a long range. These three, in summer, all have 
the head, neck, tail, and underparts pure white, the mantle gray, and the primaries black and white; but, on a near inspection, it will be found that the distribution of these colours varies in each, especially as regards the primaries; that the colours of the bills and legs are different; and that the birds themselves differ in size and structure.

In the Herring Gull the bill is yellow, with the angle of the under mandible red; eyelids, orange; irides, straw yellow; legs and toes, flesh colour. It would be difficult to choose a prettier study than a fine old bird of this species standing in bold relief against the dark limestone rock, a bunch of samphire at its feet, and by its side the large and comfortable nest, with its blotched and spotted eggs. The nest is usually made of dry grass, but a foundation is often laid of large dry stalks of heath or sea-weed. We have seldom found more than three eggs in a nest; and having frequently counted but three young birds, it may be inferred that this is the usual complement. The young, when first hatched and lying still in the nest, so closely resemble the eggs in colour that it is difficult to distinguish or count them. It is not until they have begun to get the 
use of their wings that they become lighter in plumage, and it is evident that their parents must assist them to the water, for we have seen young gulls of this and other species swimming about with the old birds long before they could fly. They are three years in acquiring the adult plumage; and, in all probability, do not breed before this is fully assumed. We have looked in vain, during the nesting season, for immature or spotted birds amongst many hundreds of old ones.

From their habit of preying upon the herring fry, and other surface-feeding fish, they have received the name of Herring Gull. There is no doubt, however, that they are quite as omnivorous as others of the genus. Crabs and shrimps are daily items in the bill of fare, and mice and young birds are sure to be pounced upon when they come in the way. We have repeatedly seen Herring Gulls following the plough and seizing worms and larvæ from the newly-turned soil. It is reported also that this bird feeds on grain.

It is easily tamed, and will breed in confinement. The young have several times been reared in the gardens of the Zoological Society, and other in- 
stances have been from time to time recorded. A pair of these birds, which had recovered the use of clipt wings in the Gardens just mentioned, for several successive years took their departure in the spring and returned again in autumn. Whether they instinctively repaired to rear their young in the meantime, it is impossible to determine; but this was not improbably the case. We have heard of several instances in which tame birds of this species flew at large for weeks and months, returning at intervals to be fed by their owners.

The cry of the Herring Gull is not unlike that of the Common Gull, a sort of hoarse laugh or cackle, sounding like "wa-agh-agh-agh." Sometimes a barking cry is preceded by a prolonged squeal, like "whee-e-e-kiark-kiark-kiark-kiark," and is generally uttered when they are frightened from the nest.

The practice of indiscriminately shooting Gulls for what is called "sport," and for the sake of gratifying a fashionable rage for feathers, cannot be too strongly deprecated, especially when it is known that the unfortunate birds are most persecuted at a time when they have eggs or young, 
because they are then more readily approached. Such a practice must inevitably lead to the total expulsion of many species from our cliffs. A rock without Sea-gulls is shorn of half its beauty; and all true naturalists must rejoice that recent legislation has provided for the protection during the nesting season of the birds whose companionship at the sea-side adds so much to the pleasure of a walk.

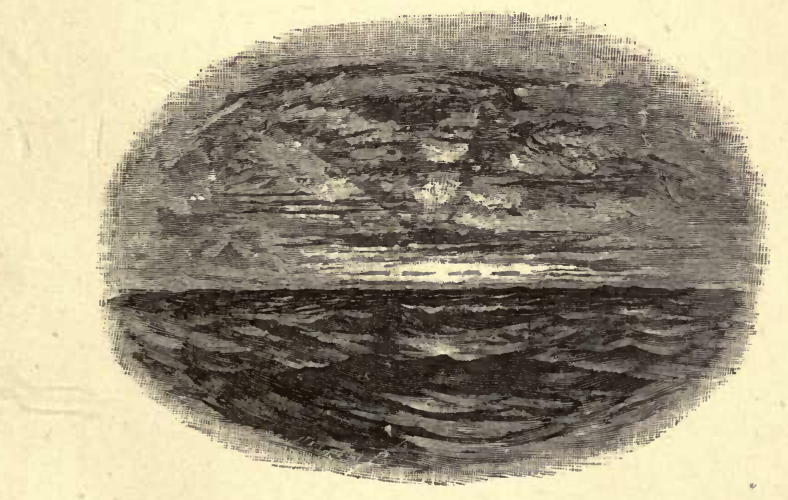





\section{INDEX.}

AlDER, attraction to the Siskin, I 34 .

Avocet, nesting in England, 242.

Baldamus, theory on Cuckoo's eggs, 189.

Barnefield, R., lines on Nightingale, 57.

Beechmast eaten by many birds, 87 , I $4 \mathrm{I}$.

Bees destroyed by Tits, 89 .

Birdcatchers, 143.

Birds singing at night, 56 ; travelling at night, I 49.

Blackbird, 32-38; migration of, 33 ; food of, 35 ; pairing with Thrush, 37 ; assiduity in feeding young, 37 ; pied and white, 38.

Blackcap, 64-69; food of, 66-67 ; nest and eggs of, 67 ; song of, 66 ; remaining in winter, 69.

Blue Tit, food of, 95 ; assiduity in feeding young, 96 .

Bond, F., on food of Blue Tit, 95 ; on nesting of Coal Tit, III.

Bones for Titmice, 97.

Booth, E. T., on migration of

Goldcrest, 127 ; on nest of Brambling, I 45 ; on nest of Tree Sparrow, I 78.

Brambling, I 39-I 45 ; migration of, I 4O-I 4 I ; travelling at night, I 42 ; nesting in Scotland, 145. Browne, Sir Thomas, on the Nightingale, 58 ; on nesting of the Spoonbill, 242.

Bullfinch, I 59-I 64 ; picking off buds, I6o ; haunts of, I6I-I 62 ; food of, 163 ; nest of, 163 .

Buntings, 49, 90, I 22.

Caterpillars, destroyed by Whitethroat, $8 \mathrm{I}$.

Census, an ornithological, 166. Chaffinch, I 46-I 5 I ; migration of, I 48 ; nesting of, I 49 ; curious nests of, I 50 ; hybrid between Chaffinch and Brambling, I 45. Cordeaux, J., on migration of the Goldcrest, 127.

Cowper's Winter Walk, 50.

Crested Titmouse,. I I 2; rare in England, I I4; its nest and eggs, I I 8.

Cuckoo, I 85-195; its habits, I 89; coloration of eggs, 192-I94; note of, 195.

Curlew, 247-258; on the moors, 252 ; on the coast, 253 ; sense of sight and hearing, 254 ; decoying a, 254 ; variation in size, 255 ; loud note of, 256 ; food of, 257 . 
DRAYTON's “Woosel," 33.

EPITAPH on a Robin, 55. Ettrick Shepherd and Merlin, I 3.

FALCONRY, 9.

Fen-birds, 238-240.

Fieldfare, 39-47; nesting of, 43 ; food of, 46.

Field mice, 16, 2 I.

Fletcher's "bird forlorn," 58.

GARDEN Warbler, 70-76 ; distribution of in England, 71-72 ; partiality for fruit, 74 ; nest of, 75.

Gascoigne's Sonnet on the Sparrow, 172.

Golden-crested Wren, I 26-1 32 ; at sea, 127 ; migration of, 127 I 28 ; sensitiveness to cold, 129 ; song of, I $3 \mathrm{I}$.

Grahame, Birds of Scotland, 33. Gray, Robert, on migration of Goldcrest, I 30 ; on the Crested Tit in Scotland, I I 5, I 6.

Greenfinch, I 52-I 58 ; habits of,

I 55 ; roosting on the ground, I 56 ; food of, I 57 ; docility as a cage bird, 158.

Green lanes, I6I-I 62.

Gull, Herring, $280-287$; its distribution, 282-283; nest and eggs, 284 ; food of, 285 ; note of, 286 .

HAwKs, protected by statute, Io, I 2 ; and keepers, I 3.
Hedge-popping, 40.

Heron, 259-269; haunts and habits, 260-26I ; food of, 262 ; mode of feeding, 264-265; nesting, 267; anecdotes of, 268.

Heronries, 265.

Hewitson's Eggs of British Birds, 42,60 .

Hoopoe, 196-202 ; breeds in England, 197; habits, I99; note of, 201 ; occurrence in winter, 202.

JAY, I80-185; food of, 183 ; inquisitive habits, 184 ; nest and eggs of, 184 .

KEEPERS and Hawks, 13.

Keeper's tree, the, 182.

Kestrel, 9-I7; numerous in autumn, I 5 ; food of, I 6 ; nesting of, 17 .

Knapp, Journal of a Naturalist, $96-7,125,148$.

LAPWING, 2 I 3-2 I 9 (see Peewit).

Lesbia and her Sparrow, I 72.

London birdcatchers, 143.

Long-tailed Tit, I I 9; nest of, I 2 I ; congregating for warmth, I24; note of, I 24 .

MACGILLIVRAY, accurate observations of, 26-7, 31, 35-6-7, 87, 96, I 1 I, 121 .

Market gardens of Kent and Surrey, 65 . 
Marsh Tit, distinguishing characteristics, I00, 106.

Merlin, I 3.

More, A. G., on distribution of birds, 22, 7 I, I 36.

NEsts, odd places for, 97,98 , I 04, I I I, I 7 O.

Nettle-creeper, 77.

Newton, A., on migration of Thrush, 28 ; on Parus britannicus, 108; on food of Coal Tit, IIO; on an ornithological census, I 66 ; on Cuckoo's eggs, I90, 192.

Nightingale, $56-63$; leaning "uptill a thorn," 57 ; distribution in England, 6I ; arrival and departure, 62 ; winter quarters, 63 .

Nightjar, I 4.

OCCUPATION roads, I6I.

Ornithological census, I 66.

Ouzel, the French Oisel, 33.

Owls and game, 24 .

Owl, Shorteared, I 8-24; food of, 21 ; nest of, 22 ; in a rabbit burrow, 23 .

PARTRIDGES, I 5, I 9, 76, I 22, I 67. Partridge and Sparrow, comparative abundance of, I 66-I 67. Peewit, 2 I 3-2 I9; eggs, 2 I 3, 2 I 4, 217 ; haunts of, 2 I 5 ; food of, 2 I 8 ; on the shore, 2 I 8.

Pettychaps, $7 \mathrm{I}$.

Pheasant, I 22.

Philip Sparrow, I 7 I-I 72.

Pigeon, 122.
Plover, Golden, 203-2 12 ; haunts, 204-205; restless before rain, 205 ; shooting, 206-207 ; breeding, 208; note of, 209-2I I ; food of, 2 I I ; young, 222. Plover's eggs, 2 I 3,2 I 4,2 I 7. Pochard, nesting of the, 263. Pomfret's "Mourning Philomel," 58.

Prévost, on the food of birds, I 68-9.

RAT and Heron, anecdote of, 268. Redbreast covering the dead with leaves, 5I-52.

Ringed Plover, 2 I 7.

Robin, 48-55; song of the, 49 ; familiar name for, 51 ; food of,

53 ; Robin and Wren, 52 , 53. Rogers' Epitaph on a Redbreast, 55.

Rowley, Dawson, on Cuckoo's eggs, I 93 .

Ruddock, $5 \mathrm{I}$.

Ruff and Reeve, 238-247 ; habits, 244 ; nidification, 244 ; curious frill, 245 ; migration, 245-246.

SELBY, on nest of Long-tailed Tit, I 22.

Shooting: Fieldfares, 40; Curlew, 253; Plover, 206; Snipe, 215,276 ; Teal, 277 ; Woodcock, 19, 224.

Siskin, 133-138; its breeding haunts, I 37 ; nesting near London, 137.

Skelton's Elegy on the Death of a Pet Sparrow, I 7 I. 
Snails and Thrushes, 30, 35 . Snowberry liked by Tits, 104 . Sparrow-hawk, I 3.

Sparrow, House, I65-1 72; following cultivation, 165 ; foes of the, I67; utility of, I67-168; food of, 169 ; nesting in odd places, I 70; struck by lightning, I 7 I ; celebrated by poets, I 72. Sparrow, Tree, I73-179; distribution of, 174-1 75 ; nesting of, I 77 ; food of, 178 ; distinguishing characteristics, 179.

Spenser's Epithalamium, 5 I.

Spoonbill nesting in England, 242. Stanley, Familiar History of Birds,

I 70.

Stevenson, on migration of Blackbird, 34; on food of Marsh Tit, I04.

Sweet's British Warblers, 66.

TEAL, 269-279; haunts, 269; actions of, 272 ; moulting, 274 ; nest described, 275 ; anecdote of, 276 ; habits, 279.

Thompson, Birds of Ireland, 24, $69,176$.
Thrush, 25-3I ; song of, 27 ; migration of, 28 ; food of, 31 ; unknown in Shetland, 27.

Titmouse, Great, 83 ; cracking nuts, 88 ; Blue, 91 ; Marsh, 99; Coal, I06; Crested, I1 2 ; Long-tailed, I 19.

WALNUTS and Tits, 88.

Walton, Izaak, the honest Robin, 52.

Warbler, Garden, absent from Wales, 72 ; song of, 73 ; nest of, 75 .

Webster's Lines on the Robin, 52.

Whitethroat, 77-82; Greater and Lesser, 78 ; haunts of, 79 ; nest of, 80 ; unknown in Ireland, $8 \mathrm{I}$. White, Gilbert, 61, 7 1, 197.

Woodbirds in November, $180-181$. Woodcock, 19, 220-237 ; nesting in England, 220; change of habits, 22 I ; plentiful in Sussex, 222 ; carrying its young, 223 , 237 ; in Scotland, 226.

Woodpecker, Green, 19.

Wren, 52-53.

THE END. 



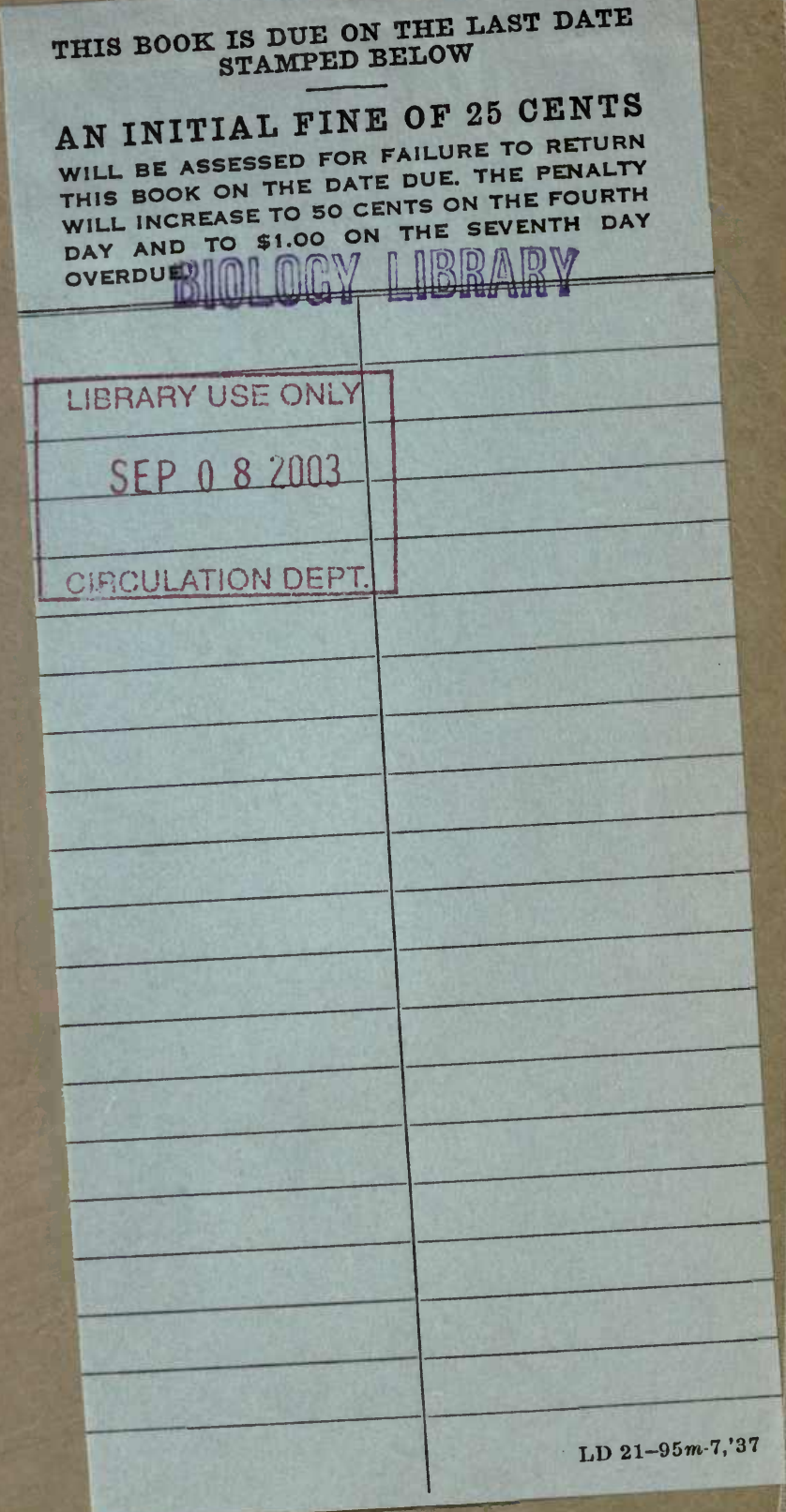




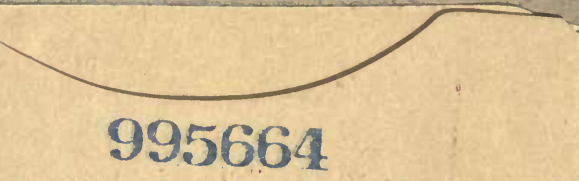

$$
\begin{aligned}
& \text { QL690 } \\
& \text { G7H43 }
\end{aligned}
$$

DIOLOGY LUBRARY

G 
